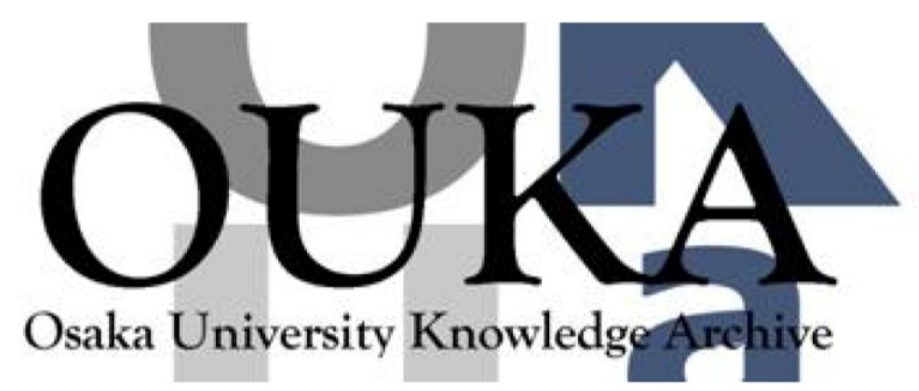

\begin{tabular}{|c|l|}
\hline Title & POLY(VINYL ALCOHOL)-IODINE REACTION \\
\hline Author(s) & 菊川, 清 \\
\hline Citation & \\
\hline Issue Date & \\
\hline oaire:version & VoR \\
\hline URL & https://hdl. handle. net/11094/30670 \\
\hline rights & \\
\hline Note & \\
\hline
\end{tabular}

Osaka University Knowledge Archive : OUKA

https://ir. Library. osaka-u. ac. jp/

Osaka University 
POLY(VINYL ALCOHOL)-IODINE REACTION

CONTENTS

Introduction

Chapter I

Preparation of Poly(vinyl alcohol) Containing

Various Amount of the 1,2-Glycol Structure

via Cyclopolymerization of Divinyl Esters

of Dibasic Acids.

1. Preparation and Polymerization of Divinyl Carbonate

2. Structure of Poly(vinyl alcohol) derived from Polymers of Divinyl Carbonate ...

3. Cyclopolymerization of Divinyl Esters of Dibasic Acids and Structure of Poly(vinyl alcohol) derived from the Polymers $\ldots . .19$

4. Copolymerization of Divinyl Carbonate ... 39

Chapter II

Effect of 1,2-Glycol Structure and Stereo-

regularity of Poly(vinyl alcohol) on Poly-

(vinyl alcohol)-Iodine Reaction

46

Chapter III Poly(vinyl alcohol)-Iodine Reaction of

Poly(vinyl alcohol) fractionated by

Foaming 
Poly(vinyl alcohol)-Iodine Reaction

\section{Introduction}

Since the blue color reaction of poly(vinyl alcohol)(PVA) with iodine was observed by Herrmann et al. ${ }^{1)}$ and staudinger et al. ${ }^{2}$ ) as early as 1927, numerous investigators have demonstrated the effects of the reaction conditions and the structure of PVA on this reaction. Effect of the reaction conditions was studied systematically in detail by Zwick ${ }^{3}$ ) and a helical structure of the PVA-iodine complex was proposed.Hayashi et al. noted that the dilute aqueous solution of partially saponified poly(vinyl acetate)(PVAc) colored red by treating with iodine as PVAc did, but that of partially acetylated PVA did not turn red with iodine, even if both were equal in the average degree of acetylation ${ }^{4)}$. Imai et a1. reported that the PVA-iodine reaction is sensitive to molecular weight and stereoregularity ${ }^{5)}$. Longer and more syndiotactic PVA display higher color intensities under the same conditions than polymers with shorter chains and more random molecular configuration. A quantitative relationship was establised between molecular weight and the color intensity of the PVA-iodine reaction and the more syndiotactic polymer reported to exhibit more intensive color.

Onthe other hand, it has been known that the variation at 
the molecular fine structure of PVA influences the properties of PVA. For example, Murahashi et al. noted that isotacticity and the 1,2-glycol structure lower the melting point and deteriorate the crystallinit ${ }^{6,7}$ ).

Imai et a1. separated a PVA derived from PVAc into fractions by foaming an aqueous solution ${ }^{8)}$. Fractions showed different reactivity to the PVA-iodine reaction inspite of little difference of degree of polymerization and $1,2 / g 1 y c o l$ content. They have suggested that the PVA have been separated according the stereoregularity.

This work was undertaken to study the effect of the structural variations on the PVA-iodine reaction and to make an approach to the elucidation of the structure of the PVA-iodine complex.

Chapter I describe the preparation of atactic PVA having various amount of the 1,2-glycol structure, in other words head-to-head, starting from a new monomer, divinyl carbonate. Further study was made on the cyclopolymerization of homologous divinyl esters in the hope of synthesizing PVA rich in the 1,2-glycol structure. Divinyl carbonate was found to the most suitable monomer for this purpose. In addition copolymerization parameters of divinyl carbonate were determined.

Effect of the 1,2-glycol structure and stereoregularity on the PVA-iodine reactions was studied in Chapter II. The presence of the 1,2-glycol structure in atactic PVA did not change the 
structure of the complex but decreased the concentration of the complex, whereas isotacticity not only decreased the concentration but also modified the structure of the complex. The shortest sequence which is needed for the complex formation was estimated to be 120 monomeric unit of the atactic structure.

In Chapter III foam fractionation of aqueous PVA solution were carried out according to Imai et a1. ${ }^{8)}$ It was confirmed that the intensity of the PVA-iodine color reaction decrease with the increase of the fraction numbers. The origin of this difference was pursued from the view point of structural variations such as molecular weight, stereoregularity, the 1,2-glycol content, and the carbonyl content but none of these factors could elucidate the difference. Short branching was suggested as a probable factor which will influence the iodine-color reaction as we11 as the foam fractionation. 


\section{References}

1. W. O. Herrmann and W. Haehne1, Ber., 60, 1658(1927)

2. H. Staudinger, K. Frey and W. Starck, Ber., 60, 1782 (1927)

3. M. M. Zwick, J. App1. Polym. Sci., 9, 2393(1965)

4. S. Hayashi, C. Nakano and T. Motoyama, Kobunshi Kagaku, 20, $303(1963)$

5. K. Imai and M. Matsumoto, J. Polym. Sci., 55, 335 (1961)

6. M. Sumi, K. Matsumura, R. Ohno, S. Nozakura and S. Murahashi, Kobunshi Kagaku, 24, 606(1967)

7. K. Kikukawa, S. Nozakura and S. Murahashi, Kobunshi Kagaku, 25, $19(1968)$

8. K. Imai and M. Matsumoto, Bu11. Chem. Soc. Japan, 36, 455 (1963) 
Chapter I

Preparation of Poly(vinyl alcohol) Containing Various

of the 1,2-G1ycol Structure via Cyclopolymerization

of Divinyl Esters of Dibasic Acids.

I -1

Preparation and Polymerization of Diviny1 Carbonate

Synopsis

The preparation of divinyl carbonate has been described. The cyclopolymerization of the monomer has been studied under various reaction conditions, and it has been found that cyclopolymerization is not a predominant mode of propagation, for it leaves not less than half a mole of unsaturation per unit structure. The polymer structure has been analyzed by the infrared method and found to contain the 5-membered cyclic carbonate unit, the 6-membered cyclic carbonate unit and the pendant unsaturated carbonate unit.

The polymerization temperature has been shown to have a significant effect on the 5-membered cyclic unit content, increasing the temperature resulting in an increase in the 5 -membered unit. 
The activation energy difference between the intramolecular 5membered cyclization and the intermolecular propagation has been estimated to be $6.21+0.29 \mathrm{kcal} / \mathrm{mol}$ in the polymerization in a $50 \%$ benzene solution and $8.44+0.48 \mathrm{kcal} / \mathrm{mol}$ in bulk polymerization. 


\title{
The Preparation and Polymerization of Divinyl Carbonate*
}

\author{
By Shunsuke Murahashi, Shun'ichi Nozakura, Saburo Fujl \\ and Kiyoshi KikuKawa
}

(Received March 15, 1965)

Since Butler ${ }^{1)}$ found the principle of the intra-inter polymerization of divinyl compounds, many divinyl compounds have been reported to undergo cyclopolymerization, yielding soluble polymers.

Divinyl carbonate seems, considering its structural analogy to divinyl thiocarbonate, ${ }^{2)}$ to be a monomer with the possibility of cyclopolymerization. The hydrolysis of the cyclized polymer might yield polyvinyl alcohol, which in turn might show some features of the cyclopolymer with stereoregularity. ${ }^{3)}$ The present study started from such point of view.

Divinyl carbonate has not previously been successfully prepared. In the present paper we wish to report the synthesis of divinyl carbonate and its polymerization, emphasis being laid on the cyclopolymerization of the monomer under various conditions. The identification of cyclic units in the polymer and the estimation of the degree of cyclization have been made by means of infrared analysis based on the study of model compounds.

\section{Experimental}

The Preparation of Divinyl Carbonate.-Divinyl carbonate was synthesized by the reaction of mer-

\footnotetext{
* Part of this paper was presented at the 17th Annual Meeting of the Chemical Society of Japan, April, 1964.

1) G. B. Butler and R. J. Angelo, J. Am. Chem. Soc., 79, 3128 (1957).

2) H. R. Ringsdorf and C. G. Overberger, Makromol. Chem., 44/46, 418 (1961).

3) S. Murahashi, H. Yuki, T. Sano, U. Yonemura, H. Tadokoro and X. Chatani, J. Polymer Sci., 62, 577 (1964).
}

curidiacetaldehyde with phosgene in tetrahydrofuran. A mixture of $220 \mathrm{~g}$. of mercuridiacetaldehyde,") $150 \mathrm{ml}$. of tetrahydrofuran, and $0.5 \mathrm{~g}$. of hydroquinone was placed in a $500 \mathrm{ml}$. three-necked flask equipped with a reflux condenser with a calcium chloride tube, a stirrer and a glass gas inlet tube, the flask was then cooled with an ice bath. Phosgene $(29 \mathrm{ml}$.), which had been condensed in a graduated trap cooled in a dry ice-acetone bath, was gradually evaporated through a phosphorus pentoxide tube into the flask while its contents were being stirred. The flask was then kept at $0^{\circ} \mathrm{C}$ for $1 \mathrm{hr}$. while being stirred, kept at room temperature for another hour, and then warmed slowly up to $60^{\circ} \mathrm{C}$. The reaction, which was not complete at $0^{\circ} \mathrm{C}$, yielded vinyl chlorocarbonate as a main product. The volatile components of the reaction mixture were collected by vacuum distillation at room temperature, and then the distillate was subjected to fractional distillation at reduced pressure using a fractional column of about 30 theoretical plates. The yield was $17 \mathrm{~g}$., $40 \%$ based on mercuridiacetaldehyde. Colorless liquid, b. p. 103.5$104.5^{\circ} \mathrm{C}, \quad 49.0-49.2^{\circ} \mathrm{C} / 98 \mathrm{mmHg}, \quad$ m. p. $-38.0-$ $-38.5^{\circ} \mathrm{C}, n_{\mathrm{D}}^{25} 1.4135, d_{4}^{25} 1.0095$.

Found: C, 51.92; H, 5.22. Calcd. for $\mathrm{C}_{5} \mathrm{H}_{6} \mathrm{O}_{3}$ : C, $52.63 ; \mathrm{H}, 5.25 \%$.

The Synthesis of Carbonates. - Trimethylene carbonate was prepared by a known method's from $45 \mathrm{~g}$. of diethyl carbonate, $25 \mathrm{~g}$. of 1,3-propanediol and $0.2 \mathrm{~g}$. of sodium. B. p. $115-116^{\circ} \mathrm{C} / 2 \mathrm{mmHg}$; m. p. $47.0-47.5^{\circ} \mathrm{C}$ (recrystallized from ether). 'Yicid. $27 \%$.

\footnotetext{
4) A. N. Nesmeyanov, R. M. Khomtov and I. F. Lutsenko, Izvest. Akad. Nauk SSSR., Otdel. Khim. Nauk, 1957, 942.

5) L. Hough and J. E. Priddle, J. Chem. Soc., 1961, 581.
} 
2,3-Butanediol cyclic carbonate was prepared from $25 \mathrm{~g}$. of 2,3-butanediol, $45 \mathrm{~g}$. of diethyl carbonate and $0.1 \mathrm{~g}$. of sodium. The mixture was then heated for $5 \mathrm{hr}$. at $120^{\circ} \mathrm{C}$, the ethanol thus formed being distilled through a Vigreux column. After the distillation of ethanol had ceased, the reaction mixture was distilled under reduced pressure twice, thus yielding $19 \mathrm{~g}$. of the product $(60 \%)$, b. p. $78-$ $79^{\circ} \mathrm{C} / 4 \mathrm{mmHg}$.

Found : $\mathrm{C}, 51.78 ; \mathrm{H}, 6.88$. Calcd. for $\mathrm{C}_{5} \mathrm{H}_{8} \mathrm{O}_{3}$ : C, $51.72 ; \mathrm{H}, 6.89 \%$.

2,4-Pentanediol cyclic carbonate was prepared in a manner similar to that used for 2,3-butanediol cyclic carbonate, using $10 \mathrm{~g}$. of 2,4-pentanediol, $15 \mathrm{~g}$. of diethyl carbonate and $0.1 \mathrm{~g}$. of sodium. The yield was $7 \mathrm{~g}$. $(54 \%)$. B. p. $129-130^{\circ} \mathrm{C} / 7 \mathrm{mmHg}$, m. p. $12.5-13.0^{\circ} \mathrm{C}$.

Found: C, $55.37 ; \mathrm{H}, 7.78$. Calcd. for $\mathrm{C}_{6} \mathrm{H}_{10} \mathrm{O}_{3}$ : C, $55.39 ; \mathrm{H}, 7.75 \%$.

For the preparation of ethyl vinyl carbonate, a mixture of $60 \mathrm{~g}$. mercuridiacetaldehyde, $15 \mathrm{~g}$. of ethyl chlorocarbonate and $30 \mathrm{ml}$. of tetrahydrofuran was stirred in a three-necked flask equipped with a reflux condenser and a stirrer, first at room temperature for several hours, and then at gradually increased temperatures up to $65^{\circ} \mathrm{C}$. The volatile component of the reaction mixture was collected in a trap cooled by a dry ice - acetone bath in a vacu$\mathrm{um}$, and then fractionally distilled, yielding $11 \mathrm{~g}$. of the product $(69 \%)$, b. p. $71-72^{\circ} \mathrm{C} / 176 \mathrm{mmHg}$.

Found : $\mathrm{C}, 50.98 ; \mathrm{H}, 6.75$. Calcd. for $\mathrm{C}_{5} \mathrm{H}_{8} \mathrm{O}_{3}$ : C, $51.72 ; \mathrm{H}, 6.89 \%$.

Propylene carbonate, a commercial product, was used after distillation and the gas chromatographic comfirmation of its purity.

The solvents for the polymerization experiments were purified by standard procedures.

Polymerization.-An ampoule containing a monomer, a solvent and benzoylperoxide $(0.5 \mathrm{~mol} . \%$ of the monomer) or 2,2'-azobisisobutyronitrile was degassed three times in a high-vacuum manipulation and then sealed. Polymerization was carried out in a thermostat at $60 \pm 0.05^{\circ} \mathrm{C}$

In the photo-sensitized polymerization, a solution of the monomer and 2,2'-azobisisobutyronitrile in benzene was irradiated with a ultraviolet lamp (Toshiba SHL 100-UV) in a vacuum, using a vessel with a fused silica window.

After polymerization, a small amount of an in- hibitor, p-t-butylcatechol, was introduced into the polymerization mixture, and then the residual monomer and the solvent are stripped in a vacuum at room temperature. The residual crude polymer was treated with acetone. The acetone-soluble fraction was precipitated with petroleum ether. In some experiments the polymerization mixture was poured into a large amount of hexane, yielding a precipitate of the polymer. The polymer was dried at room temperature in vacuo.

A typical example of the analysis of the polymer is shown below for the sample of Exp. No. 1 in Table V.

Found: C, $52.61 ; \mathrm{H}, 5.29$. Calcd. for $\mathrm{C}_{5} \mathrm{H}_{6} \mathrm{O}_{3}$ : C, $52.62 ; \mathrm{H}, 5.31 \%$.

Infrared Spectra. - The absorption coefficients of the model compounds were determined in chloroform, as it was confirmed that the Lambert-Beer law was applicable at concentrations from 0.02 to $0.5 \mathrm{~mol} . / \mathrm{l}$. The infrared spectra of the polymer were taken by the KBr-tablet method.

\section{Results}

The Infrared Analysis of the Polymer Structure.-An infrared spectrum of the polymer, shown in Fig. 1, has two carbonyl absorptions, at 1810 and $1760 \mathrm{~cm}^{-1}$, and a double bond absorption at $1660 \mathrm{~cm}^{-1}$. To identify these absorptions, the infrared spectra of model compounds were studied, they are listed in Table I. It can there be seen that the band at $1810 \mathrm{~cm}^{-1}$ in the polymer corresponds to 2,3-butanediol cyclic carbonate (1810) and closely corresponds to propylene carbonate (1800), thus indicating that the 1810 band may be due to the presence of a 5-membered carbonate. The band at $1760 \mathrm{~cm}^{-1}$ of the polymer corresponds to 2, 4-pentanediol cyclic carbonate (1750), trimethylene carbonate (1755), and also to ethyl vinyl carbonate (1760), indicating that this band may originate from the unsaturated carbonate of 1,2-addition type, presumably being overlapped with a 6-membered cyclic carbonate. Thus, the structure of the polymer may be represented by Formula I:

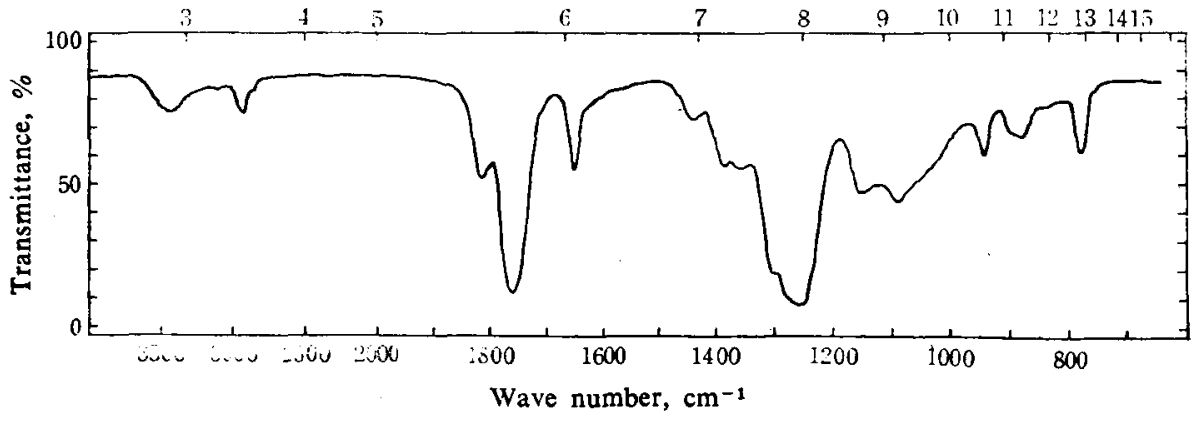

Fig. 1. Infrared spectrum of polydivinylcarbonate. 


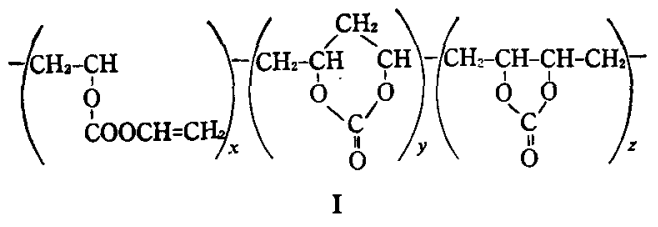

Using the following notations:

\begin{tabular}{|c|c|c|c|c|}
\hline $\begin{array}{l}\text { Polymer } \\
\text { structure }\end{array}$ & $\begin{array}{l}\text { Molar } \\
\text { conen. }\end{array}$ & \multicolumn{2}{|c|}{$\begin{array}{l}\text { Absorption } \\
\text { coefficient }\end{array}$} & $\begin{array}{l}\text { Observed } \\
\text { absorbance }\end{array}$ \\
\hline $\begin{array}{l}\text { Unsaturated } \\
\text { carbonate }\end{array}$ & $C_{1}$ & $\left\{\begin{array}{l}C=C \\
C=O\end{array}\right.$ & $\begin{array}{l}\varepsilon_{1} \\
\varepsilon_{2}\end{array}$ & $D_{1}\left(1660 \mathrm{~cm}^{-1}\right)$ \\
\hline $\begin{array}{l}\text { 6-Membered } \\
\text { carbonate }\end{array}$ & $C_{2}$ & & & $D_{2}\left(1760 \mathrm{~cm}^{-1}\right)$ \\
\hline $\begin{array}{l}\text { 5-Membered } \\
\text { carbonate }\end{array}$ & $C_{3}$ & & $\varepsilon_{4}$ & $D_{3}\left(1810 \mathrm{~cm}^{-1}\right)$ \\
\hline
\end{tabular}

the molar concentrations of the three structural units can be expressed as;

$$
\begin{aligned}
& C_{1}=D_{1} / \varepsilon_{1} l \\
& C_{2}=\left(D_{2}-\varepsilon_{2} D_{1} / \varepsilon_{1}\right) / \varepsilon_{3} l \\
& C_{3}=D_{3} / \varepsilon_{4} l
\end{aligned}
$$

where $l$, denotes the thickness of a specimen. Assuming that the absorption coefficients of the three structural units can be represented by those of the corresponding model compounds in solution, the following expressions result :

$$
\begin{aligned}
& C_{1}=D_{1} / 494 l \\
& C_{2}=\left(D_{2}-2.97 D_{1}\right) / 1819 l \\
& C_{3}=D_{3} / 1960 l
\end{aligned}
$$

The relative amounts of $C_{1}, C_{2}$ and $C_{3}$ can be calculated independently of the thickness, $l$. The absorption bands at 1810 and $1760 \mathrm{~cm}^{-1}$ in the polymer, which overlapped each other, were separated as shown in Fig. 2. The 6membered cyclic carbonate content was not determined directly, but it was calculated on the basis of the difference in the observed absorbance of unsaturated carbonate as calculated from the $\nu_{\mathrm{c}}=\mathrm{c}$ band at $1660 \mathrm{~cm}^{-1}$. Therefore, its value is likely to have some error and to be less reliable. Cross-linking due to the pendant unsaturation may not be large,

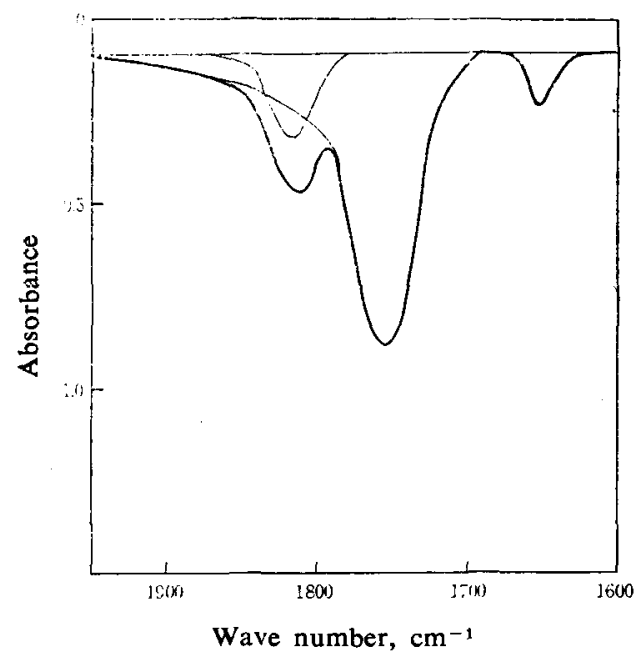

Fig. 2. Analysis of an infrared spectrum of polydivinyl carbonate.

but its increase will result in the overestimation of the 6-membered carbonate in the above calculations. This is another source of error in the estimation of the 6-membered carbonate.

The Effect of Polymerization Variables on Polymer Properties.-Gel point conversion may represent a qualitative measure of the degree of cyclization. ${ }^{2)}$ The effect of the monomer concentration on the gel point conversion is shown in Table II. When a visible gellation had taken place, almost the entire polymer was found to become insoluble; the monomer concentration in this case did not have any appreciable effect on the gel point conversion.

As it has been shown that, at a gel point conversion, almost the entire polymer becomes insoluble, the solubility of the polymers was examined at various points of conversion. The polymer was fractionated into a soluble part and an insoluble part by digesting the precipitated polymer with acetone at room temperature. The results are shown in Table III. The first appearance of gellation was observed after about $75 \mathrm{~min}$. polymerization, but the insoluble

TABLE I. INFRARED ABSORPTION COEFFICIENTS OF THE RELATED MODEL COMPOUNDS

$\begin{array}{lcccc}\quad \text { Carbonate } & \nu \mathrm{c}=0, \mathrm{~cm}^{-1} & \varepsilon & \nu \mathrm{c}=\mathrm{c}, \mathrm{cm}^{-1} & \varepsilon \\ \text { Divinyl carbonate } & 1775 & 1460 & 1660 & 752 \\ \text { Vinyl ethyl carbonate } & 1765 & 1470 & 1665 & 494 \\ \text { Diethyl carbonate } & 1745 & 1110 & & \\ \text { 2, 3-Butanediol cyclic carbonate } & 1810 & 1960 & \\ \text { Propylene carbonate } & 1800 & 1490 & \\ \text { Trimethylene carbonate } & 1755 & 1970 & \\ \text { 2,4-Pentanediol cyclic carbonate } & 1750 & 1810 & \\ \text { Poly (vinylene carbonate) } & 1825 & & \end{array}$

a) H. C. Haas and N. W. Schuler, J. Polymer Sci., 31, 237 (1958). 
Table II. Polymerization and polymer structure of divinyl Carbonate at various MONOMER CONCENTRATION IN BENZENE

$60 \pm 0.05^{\circ} \mathrm{C} ;[\mathrm{BPO}]=0.5 \mathrm{~mol} . \%$ of monomer

Exp. No.

Monomer concn., \% by Vol.

Time, min.

Conversion, \% ${ }^{\text {r) }}$

Sol. and insol. part, $\%$

1,2-Addition, \%

6-Membered ring, \%

5-Membered ring, \%

\begin{tabular}{|c|c|c|c|}
\hline & 1 & & 2 \\
\hline & 70 & & 50 \\
\hline & 52 & & 77 \\
\hline & 12.2 & & 13.9 \\
\hline 0.9 & 10.0 & $\widetilde{0.5}$ & 10.9 \\
\hline- & 72 & 56 & 69 \\
\hline- & 12 & 31 & 18 \\
\hline- & 16 & 13 & 13 \\
\hline
\end{tabular}

4

10
1080

14.7

a) Polymerization was stopped at the first appearance of gellation except for No. 5 where no visible gellation was observed.

Table III. Properties of polymers obtained at Various conversions $[\mathrm{M}]=30 \mathrm{vol} . \%$ in benzene ; $[\mathrm{AIBN}]=0.5 \mathrm{~mol} . \%$ of monomer $; 60 \pm 0.05^{\circ} \mathrm{C}$

Exp. No.

Time, min.

Conversion, \%

Sol. and insol. part, \% $5 . \widetilde{0.0}$

1,2-Addition, $\%$

6-Membered ring, \%

5-Membered ring, \%

30
5.3
$-\quad 0.0$
$-\quad-$
$-\quad-$

\section{7}

90

11.6

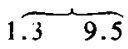

3.74 .7

$59 \quad 52$

$25 \quad 27$

$16 \quad 21$

Intrinsic viscosity of the soluble part of Nos. 5 and 6 are 0.109 and 0.118 dl. $/ \mathrm{g}$. in acetone.

TABLE IV. EFFECT OF SOLYENTS ON POLYMERIZATION OF DIVINYL CARBONATE $[\mathrm{M}]=30 \mathrm{vol} . \%$. $[\mathrm{AIBM}]=0.5 \mathrm{~mol} . \%$ of monomer $; 60 \pm 0.05^{\circ} \mathrm{C}$

Exp. No.

10

11

12

Solvent

Time, min. ${ }^{a)}$

Conversion, \%

\begin{tabular}{|c|c|c|c|c|c|}
\hline \multicolumn{2}{|c|}{ Benzene } & \multicolumn{2}{|c|}{ Toluene } & \multicolumn{2}{|c|}{ Cumene } \\
\hline \multicolumn{2}{|c|}{75} & \multicolumn{2}{|c|}{140} & \multicolumn{2}{|c|}{ No gel. } \\
\hline \multicolumn{2}{|c|}{20.1} & \multicolumn{2}{|c|}{20.1} & & 7 \\
\hline 0.5 & 20.0 & 1.5 & 15.3 & 1 & 0 \\
\hline 59 & 52 & 61 & 60 & 61 & - \\
\hline 25 & 27 & 21 & 21 & 26 & - \\
\hline 16 & 21 & & 19 & 14 & \\
\hline
\end{tabular}

13

14

15 Nitro-
benzene No gel.

Sol. and insol. part, \% 1,2-Addition, \% 6-Membered ring. \% 5-Membered ring, \%

Intrinsic viscosity of the soluble part of Nos. 12 and 14 are 0.062 and $0.080 \mathrm{dl} . / \mathrm{g}$. in acetone.

a) Time at the first appearance of gellation.

b) $\mathrm{Cl} \%=19.76$. Figures in parentheses are values corrected for chlorine, assuming that $\mathrm{CCl}_{4}$ was incorporated by a chain transfer reaction.

\section{Table V. Bulk polymerization of divinyl Carbonate at Various temperatures} Monomer, $2 \mathrm{ml}$;; AIBN $0.1 \mathrm{mmol}$.

Exp. No.

Temperature, ${ }^{\circ} \mathrm{C}$ )

Time, min.

Conversion, $\%$ b)

1,2-Addition, $\%$

6-Membered ring, \%

5-Membered ring, \%

$\begin{array}{ccc}1 & 2^{a)} & 3 \\ 60 & 45 & 30 \\ 14 & 3 & 1215 \\ 9.9 & 4.1 & 5.7 \\ 71 & 90 & 76 \\ 21 & 5.5 & 22 \\ 7.9 & 4.0 & 2.3\end{array}$

$4^{\text {a) }}$
15
70
7.5
88
11
1.2

$\begin{array}{cc}5^{(a)} & 6^{(a)} \\ 0 & -30 \\ 25 & 105 \\ 8.2 & 0.5 \\ 86 & 85 \\ 14 & 15 \\ 0.5 & 0\end{array}$

\footnotetext{
a) Photo-sensitized polymerization.

b) Polymerization was stopped shortly after gellation except for No. 6 .

c) Temperature was kept constant within $\pm 0.5^{\circ} \mathrm{C}$.
} 
polymer had been formed prior to the apparent gellation. At a conversion as low as $6 \%$, the polymer was soluble in acetone, and thereafter the fraction of the insoluble polymer increased rapidly with conversion. The soluble part softened at $250-270^{\circ} \mathrm{C}$ with a slight discoloring. The polymer structure did not show appreciable change during the course of polymerization.

The solvent was expected to influence the solubility and the structure of the resulting polymer because of the differences in the chain transfer reaction and in the polarity, the latter of which might have some special influence on the conformation of the monomer molecule and of the polymer end in solution. The results are listed in Table IV. Even carbon tetrachloride, which is known to have a large chain transfer constant in the vinyl acetate polymerization, could not prevent the gel formation. However, polymerization in acetonitrile gave a polymer of a relatively high solubility. The extraordinary high yield of the polymer in carbon tetrachloride was unexpected: the reason can not be determined at present. Hydrocarbon solvents with high chain transfer constants, such as toluene and cumene, did not have any effect on the polymer structure, but a polar solvent, acetonitrile, showed such an effect, increasing the relative content of the 5-membered cyclic carbonate structure.

The Effect of the Polymerization Temperature on the Polymer Structure.--The formation of the 5-membered cyclic structure means the head-to-head addition of two vinyl groups in the same molecule. Head-to-head addition in usual vinyl monomers is known to have a higher activation energy than that of head-totail addition, and so it is to be expected that the polymerization temperature will have an effect on the content of cyclic units. The results are shown in Tables $V$ and VI. The ratios of $C_{3} / C_{1}$, that is, the mole ratio of the 5 -membered cyclic unit to the unsaturated

Table VI. Photosensitized polymerization OF DIVINYL CARBONATE AT VARIOUS TEMPERATURE IN BENZENE ( $1: 1$ vol.)

Monomer, $2 \mathrm{ml}$.; Benzene $2 \mathrm{ml}$.; AIBM $0.1 \mathrm{mmol}$.

Exp. No.

Temperature, ${ }^{\circ} \mathrm{C}^{\mathrm{a})}$

Time, min.

Conversion, $\%$ b)

1,2-Addition, $\%$

6-Membered ring, \%

5-Membered ring, \%

$\begin{array}{llll}7 & 8 & 9 & 10 \\ 40 & 30 & 20 & 10 \\ 40 & 48 & 60 & 85 \\ 13.6 & 12.0 & 13.0 & 14 . \\ 68 & 71 & 71 & 81 \\ 25 & 24 & 25 & 16 \\ 7.7 & 5.1 & 4.1 & 3.0\end{array}$

a) Temperature was kept constant within $\pm 0.1^{\circ} \mathrm{C}$.

b) Polymerization was stopped shortly after gellation. carbonate units, is taken in an Arrhenius plot, giving the difference in the activation energies (Fig. 3):

$$
\begin{array}{r}
E_{3}-E_{1}=6.21 \pm 0.29 \mathrm{kcal} . / \mathrm{mol} . \text { in a } 50 \% \\
\text { benzene solution }
\end{array}
$$<smiles>[CH]C1OC(=O)OC1C[14CH2]OC(=O)OC=C</smiles><smiles>[M]C[C@H](C=[C]C(C=C)OC(=O)OC=C)OC(=O)OC=C</smiles>

III

Since

$$
\frac{k_{3}}{k_{1}}=\frac{1}{(\mathrm{M})} \times \frac{A_{3}}{A_{1}} \exp \left(-\frac{E_{3}-E_{1}}{R T}\right)
$$

Where (M) represents the monomer concentration in terms of the vinyl group, it follows

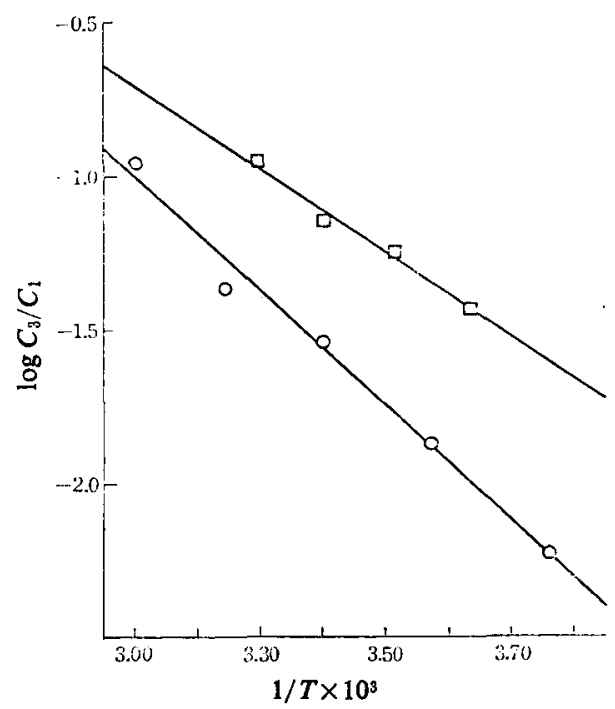

Fig. 3. Dependency of relative abundance of 5 -membered ring on temperature of polymerization.

$\square$ Solution polymerization in benzene (50 vol. \%)

O Bulk polymerization 
that;

$$
\begin{aligned}
A_{3} / A_{1} & =2.04 \times 10^{4} \text { in a } 50 \% \text { benzene solution } \\
& =5.85 \times 10^{5} \text { in bulk polymerization }
\end{aligned}
$$

\section{Discussion}

The experimental facts concerning the polymerization of divinyl carbonate at low conversions may be summarized thus:

i) The polymer structure has been found to be composed of a 5-membered cyclic carbonate unit, a 6-membered .cyclic carbonate unit, and an unsaturated carbonate unit.

ii) Cyclopolymerization is not a predominant mode of propagation, leaving not less than half a mole of unsaturation per unit structure. Hence, the polymers are likely to be crosslinked.

iii) The polymerization variables, i.e., the concentrations of the monomer, the conversion, and the solvent, had no appreciable effect on the polymer structure except for the polymerization in acetonitrile (Table IV).

iv) The polymerization temperature had a strong influence on the polymer structure, raising temperature resulting in an increased content of the 5-membered cyclic carbonate unit.

Divinyl compounds which undergo cyclopolymerization may be classified into two types. The one is compounds with unsaturated groups relatively inactive towards a radical, such as diallyl compounds and divinyl acetals. The other one is monomers with the reactive double bonds, like acrylic anhydride and its derivatives. Recently, it has been suggested, from a study of the electronic spectra, that two double bonds in a molecule of the latter type have a mutual interaction in solution and that the molecule takes a special conformation favorable to cyclization. ${ }^{6}$ The vinyl groups in divinyl carbonate belong to the latter type, its reactivity is not very different from that of vinyl acetate. ${ }^{2}$ The fact that divinyl carbonate is unlikely to undergo genuine cyclopolymerization might be due to the lack of a conformation favorable to cyclopolymerization in this case.

Gellation at the stage of low conversion is explained as being due simply to the prior existence of a large amount of the pendant vinyl groups in the polymer and to the high reactivity of the vinyl group.

The temperature dependency of the polymer structure is significant. The intramolecular

6) G. B. Butler and J. W. Brooks, J. Org. Chem., 28, 2699 (1963).

7) S. Murahashi, S. Nozakura and K. Kikukawa, to be published. formation of the 5-membered cyclic unit has a larger activation energy, from 6 to $8 \mathrm{kcal} . / \mathrm{mol}$,, than the intermolecular propagation. The difference in the activation energies between the head-to-head addition and the head-to-tail addition of the usual monomers is reported to be 1 to $3 \mathrm{kcal} . / \mathrm{mol}^{8}$ ) The formation of the 5-membered cyclic unit of divinyl carbonate implies an intramolecular cyclization as well as a head-to-head addition. Therefore, the cyclization reaction may need an additional activation energy to be able to take a conformation favorable to the ring closure.

The frequency factor of the 5 -membered cyclization reaction $\left(A_{3}\right)$ is larger than that of the intermolecular propagation $\left(A_{1}\right)$ by a magnitude of $10^{4}$ to $10^{5}$. The ratios observed in other vinyl monomers range from 0.1 to $0.7 .^{8}$ This large difference may not be unreasonable when it is considered that the reacting vinyl group in the cyclization reaction always exists in the vicinity of the reacting polymer radical. In other words, the intramolecular cyclization needs less decrease of entropy at the activated state than does the intermolecular propagation.

\section{Summary}

The preparation of divinyl carbonate has been described. The cyclopolymerization of the monomer has been studied under various reaction conditions, and it has been found that cyclopolymerization is not a predominant mode of propagation, for it leaves not less than half a mole of unsaturation per unit structure. The polymer structure has been analyzed by the infrared method and found to contain the 5-membered cyclic carbonate unit, the 6-membered cyclic carbonate unit and the pendant unsaturated carbonate unit.

The polymerization temperature has been shown to have a significant effect on the 5membered cyclic unit content, increasing the temperature resulting in an increase in the 5-membered unit. The activation energy difference between the intramolecular 5-membered cyclization and the intermolecular propagation has been estimated to be $6.21 \pm 0.29$ $\mathrm{kcal} . / \mathrm{mol}$. in the polymerization in a $50 \%$ benzene solution and $8.44 \pm 0.48 \mathrm{kcal} . / \mathrm{mol}$. in bulk polymerization.

\section{Department of Polymer Science Faculty of Science Osaka University Nakanoshima, Osaka}

8) I. Rosen, G. H. McCain, A. L. Endrey and C. L. Sturm, J. Polymer Sci., A1, 951 (1963). 


$$
\text { I - } 2
$$

Structure of Poly(vinyl alcohol) derived from

Polymers of Divinyl Carbonate

Synopsis

The structure of poly(vinyl alcohol) derived from poly(divinyl carbonate) or divinyl carbonate-vinyl acetate copolymers was studied. These poly(vinyl alcohol) were found to contain an unusually large amount of $1,2 /$ glycol structure, which is considered to due to the 5-membered ring structure in poly(divinyl carbonate) or divinyl carbonate-vinyl acetate copolymers. With increasing the $1,2-g l y c o l$ structure in poly(vinyl alcohol)(3mol\% - 45mol\%), the melting points of poly(vinyl alcohol) decreased and the infrared absorption of $\mathrm{C}-\mathrm{O}$ stretching mode shifted from $1090 \mathrm{~cm}^{-1}$ to $1050 \mathrm{~cm}^{-1}$. The melting behavior in diffrential thermal analysis was not observed in poly(vinyl alcohol) which contained the 1,2-glycol structure in more than $40 \mathrm{mo} \%$.

Variation of melting points with the contents of 1,2-glycol structure was interpreted by the Flory's theory, giving $1.67 \mathrm{kcal} / \mathrm{mol}$ for the heat of fusion of poly(vinyl alcohol) and $243^{\circ} \mathrm{C}$ for the melting point of pure poly(vinyl alcohol) 


\title{
〔5〕炭酸ジビニルの重合体より得られるポリビニルアルコールの構造
}

\author{
（1967 年 6 月 27 日受理）
}

\author{
菊川 清* ·野桜俊一 ${ }^{*}$. 村橋俊介*
}

\begin{abstract}
要 旨 ポリ炭酸ジビニル（PDVC）あるいは炭酸ジビニルー酭酸ビニル共重合体 (DVC-VAC)より 得られるポリビニルアルコール (PVA) の構造について検討した。これらの PVA は PDVCおよび

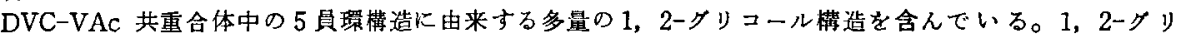
コール模造が增加するに従い $(3 \mathrm{~mol} \% \sim 45 \mathrm{~mol} \%)$. PVA の融点は低下し，赤外吸収スベクトルの CO伸縮振動む $1090 \mathrm{~cm}^{-1}$ か. $51050 \mathrm{~cm}^{-1}$ 一移動する。1，2-グリコール構造を $40 \mathrm{~mol} \%$ 以上含むPVA では，示差熱分析で堀点が認められなかった。1，2-グリコール量による融点の变化を Flory の理論に より取り报い, PVAの融解熱として $1.67 \mathrm{kcal} / \mathrm{mol}$ を得た。主た，1，3-グリコールだけからなり 1,2

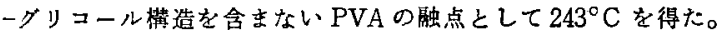

\section{1. 緒 喜}

Butler ら"Kよりシビニル化合物の分子内一分子間重 合が見出されて以来，多くのジビ二ル化合物が瓄化重合 を行ない，可溶性ポリマーを生成することが報告されて いる。

岑酸ジビニル（DVC）も同栚な環化重合により，(I) 式の(II)の薮造をもつポリマーの生成が予想される。<smiles>C[CH]OC(=O)OC(C)C</smiles><smiles>CC(C)CC(C)OC(=O)O</smiles><smiles>CCC(O)CC(C)O</smiles>

たポリマーの加水分解が行なわれればポリビニルフルコ 一ル (PVA) が得られるはずであり，環化重合により特 異な立体模造をもった PVAが得られる可能性がある。

このような矕点から，以前沉われわれは DVC の単独 重合を行ない，そのポりマーが(2)式に示したような權 造をもつことをその IR スペクトルから推定した。<smiles>CCCCCC1OC(=O)OC(CCCOC(O)O)C1O</smiles><smiles>[CH][CH]</smiles>

\footnotetext{
* 大阪大学理学部高分子学科 (大阪府豊中市待兼山町
} 1の 1)
さらにそその構造単位に及ぼす重合条件の影響を検討 した2゙。その結果，重合率，溶媒によっては大きな影響 は受けないが，重合温度により大きな影響が認められ た。

本報に和いては，ポリ炭酸ジビニル（PDVC）の加水分 解が比較的容易に行なえることを見出したので，PVA としての構造の特異性を娭討した。さらに前報において は PDVC 中の 5 員環構造の定量を, IR スベクトルによ り，モデル物質の吸光俰数を用いる仮定に基いて行なっ たので，加水分解して得られる PVA の 1，2-グリコー ル構造の定量汇より，むとの 5 員環满造の直接的確認を 行ならことる一つの目的とした。

\section{2. 实駼}

\section{1 モノマー, 溶媒}

DVCは前報に記したように，ホスダンと $\mathrm{Hg}\left(\mathrm{CH}_{2} \mathrm{CH}\right.$ O) 2 上り含成した ${ }^{2}$ 。bp $44.7 \sim 45.3^{\circ} \mathrm{C} / 85 \mathrm{mmHg}$ 。

酢酸ビニル（VAc）は重西硫酸ソーダ水溶夜で洗い， $\mathrm{CaCl}_{2}$ で乾燥した後，蒸留して用いた。2，2'ーアン゙゙゙ス イソブチロニトリル（AIBN）怰販品を EtoHより再 結晶して用いた。

\section{2 重 合}

Expt. No. 1 10 は，前報2 亿批いて，塊状および 50 vol％へンンゼン溶液で，重合温度を変化させて得た ポリマーである。低温に打いては紫外線による光增感重

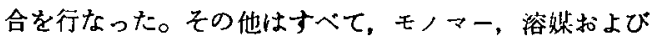
開始剂を入れたガラスフンブルを，真空亲で 3 回聪気 後, 封管して $60^{\circ} \mathrm{C}$ の恒洫槽で静置要合した。重合終了 後ゲルを含む溶液を多䁷の石油エーテル中へ性ぎ，决り マーを沈殷させ，数回のデカンテーションをくり返した のち,室温で成圧乾燥した。重合は単独重合で 10 15\%。 共重合で 15 25\%の重合率とした。すべての系で，ボ リマーの沈殷（ゲル）が生ずる。 


\section{3 ポリマーの加水分解}

$200 \mathrm{cc}$ の三角フラスコに0.2〜0.4gのボリマーをとり， アセトン $50 \mathrm{cc}$ を加え十分膨潤させる(4〜 時間)。そこ へ $1 N-\mathrm{KOH}$ 水溶液 $10 \mathrm{cc}$ を加える。このときポリマ一 のほとんどが溶解する。このまま室温で 2 3 日放置す ると完全に加水分解され，陚料 No. 1〜10の場合では PVAが沈殿してくる。その他の試料の場合には下層に溶 解している。これを多量のメタノールに注ぎ，ボリマー を沈殿させる。デカンテーションをくり返したのb、遠 心分路して（陚料 No. 1〜10 ではダスフィルターで 口別した), メタノールで洗浄し，室湿で減王乾燥した。

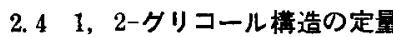

過ヨウ素酸 $\left(\mathrm{HIO}_{4}\right)$ 法によった。本報では主として， 浮田らの方法に上り3 ポーラログラフ法で $\mathrm{HIO}_{4}$ を定量 した。波高としては電解回路を切ったときの㑬を 0 点と し，一0.1V(SCE) に和ける電流值を厸散電流として用

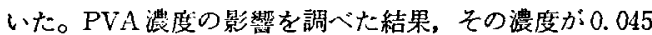
〜0.075\%の範眀でをの波高に大きな影響は認められ なかった。そこで, 約 $0.06 \%$ の水溶液として測定した。

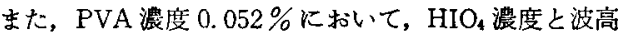
との比例性を顺討した結果, $\mathrm{HIO}_{4}$ 濃度が $0 \sim 16 \mathrm{~m} \mathrm{~mol} / l$ の範用では Table 1 に見られるように良好な比例関保 が㒛められた。

なお比較のため, Expt. No. 24〜29 の試料について は H.E. Harris らの方法"により, 反纫後の $\mathrm{HIO}_{4}$ を 定鼠して，1，2-グリコール舅を求めた。

\subsection{IR スペクトル}

約 $1 \%$ 水溶液よりフィルムを作成して，日立分光光度 計 $\mathrm{EPI}=2$ 型により測定した。

\subsection{PVAの重合度}

$1 \%$ 水溶液の粘度から中島の式”を用いて求めた。

\subsection{PVA の融点測定}

Sample No. 24〜27 については, 倉敷レイヨン株式 会社研究所において，島律示差熱分析計 DT-10型を用 いて测定した。No. 28，29 については，二キボー株式 会社瀻維研究所に扣いて，島津示差熱分析計DT - 10 型

Table 1. The proportionality between $\mathrm{HIO}_{4}$ concentration and diffusion current.

[PVA] $=0.052 \%$ at $25^{\circ} \mathrm{C}$

\begin{tabular}{c|c|c}
\hline $\begin{array}{c}{\left[\mathrm{HIO}_{4}\right]} \\
(\mathrm{m} \mathrm{mol} / l)\end{array}$ & $\begin{array}{c}i_{u} \\
(\mu \mathrm{A})\end{array}$ & $i_{d} / \mathrm{C}$ \\
\hline 0.0 & 0 & - \\
0.4 & 1.72 & 4.27 \\
0.8 & 3.42 & 4.27 \\
1.2 & 5.19 & 4.32 \\
1.6 & 6.48 & 4.27 \\
\hline
\end{tabular}

を用いて測定した（Fig. 2)。

\section{3. 桔 果}

3.1 PVA の 1，2-タリコール梏について

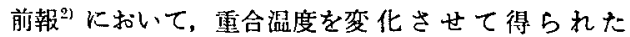
PDVCを加水分解して得られたPVAの 1，2-グリコール 量の $\mathrm{HIO}_{4}$ 酸化法による測定值を Table 2 に示した。 Table 2 にはIR スペクトルによる 5 員䍗檴造の定量値 より計算した 1，2-グリコール冒も示した。5員環满造 に由来する 1,2-グリコール權造の $\mathrm{mol} \%$ は，(3)式に より,

$$
\{2 z /(x+2 y+2 z)\} \times 100 \text { として計算した。 }
$$

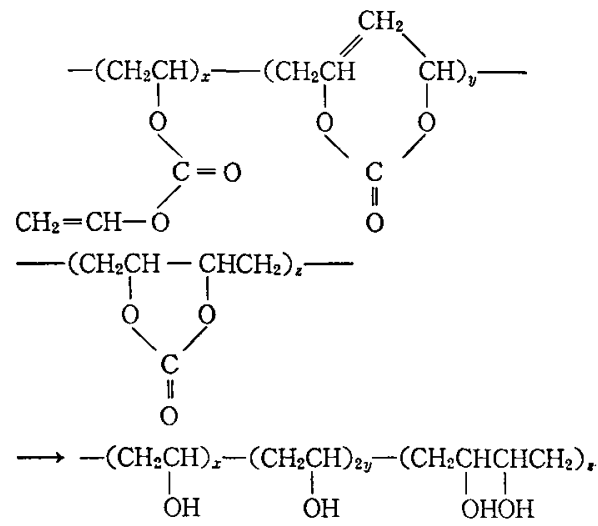

すなわち, Table 2 の 1, 2-ダシコール mol\%は, 一般に用いられている100A (100 佔のモ) マー単位の中 に含まれる1，2-グリコール構造の数）の値の 2 倍に相 当する。

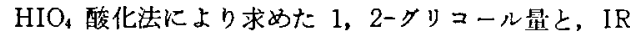
スベクトル法より求めたそれとが，5員環量の少ない範 囲（く15\%）において，かなりよい一致を示すことがわ かった。モデル化合物としてのエチルビニル炭酸の望利 重合体より得られた PVA についても Table 2 に示し たが (Sample No. 284)，その 1，2-グリュール髲は术 リ䣫酸ビニルよりの PVA よりやや多い程度である。

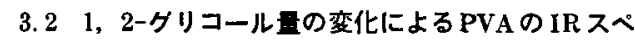
クトルおよび融点の変化

DVCはVAc とよく似た重合反応性を示すことがわか ったのでけ，DVCとVAcの共重合を行ない，その共历! 合 体を加水分解すれば，1，2-グリコール量の变化したPVA を得ることが予想される。

1, 2-グリコール量の変化によるIR スベクトル，およ び融点 $\left(T_{m}\right)$ の変化を調べるたるに，DVC-VAcの其重 合を行った結果を Table 3 に示した。またPVAのIR スペクトルをFig. 1 に示した。PVAのシンジオタク 
Table 2. 1, 2-glycol contents of PVA derived from polydivinylcarbonate.

\begin{tabular}{|c|c|c|c|c|c|c|}
\hline \multirow{2}{*}{$\begin{array}{c}\text { Sample } \\
\text { No. }\end{array}$} & \multirow{2}{*}{$\begin{array}{c}{[\mathrm{M}]} \\
(\mathrm{vol} \%)\end{array}$} & \multirow{2}{*}{$\begin{array}{l}\text { Polymerization } \\
\text { temp. }\left({ }^{\circ} \mathrm{C}\right)\end{array}$} & \multicolumn{2}{|c|}{ 1, 2-glycol contents (moi \%) } & \multirow{2}{*}{$\frac{D_{816}}{D_{849}}$} & \multirow{2}{*}{$\overline{D P}$} \\
\hline & & & obsd. & calcd. from IR & & \\
\hline 1 & \multirow{5}{*}{$\begin{array}{c}100 \\
\text { (bulk) }\end{array}$} & 60 & 13.7 & 12.2 & 0.30 & 631 \\
\hline 2 & & $45^{\circ}$ & 9.6 & 7.3 & 0.37 & - \\
\hline 3 & & 30 & 6.4 & 3.7 & 0.40 & - \\
\hline 4 & & 15 & 4. 7 & 2.1 & 0.43 & - \\
\hline 5 & & 0 & 3.5 & 0.9 & 0.45 & - \\
\hline 7 & \multirow[t]{4}{*}{50} & 40 & 10.8 & 11.5 & 0.34 & 593 \\
\hline 8 & & 30 & 7.6 & 7.9 & 0.33 & 610 \\
\hline 9 & & 20 & 5.7 & 6.3 & 0.26 & 606 \\
\hline 10 & & 10 & 6.7 & 5.0 & 0.33 & 623 \\
\hline 23 & 11.4 & 60 & 30.0 & 42.8 & 0.18 & - \\
\hline $284^{*}$ & bulk & 60 & 4.7 & - & 0.23 & 196 \\
\hline \multicolumn{2}{|c|}{ Commercial PVA } & & 3.3 & & & 500 \\
\hline
\end{tabular}

* Sample No. 284 was derived from polyethylvinylcarbonate.

Table 3. The IR spectra, melting points and 1, 2-glycol contents of PVA derived from DVCVAc copolymers and PDVC.

\begin{tabular}{c|c|c|c|c|c|c|c}
\hline $\begin{array}{c}\text { Expt. } \\
\text { No. }\end{array}$ & $\begin{array}{l}\text { DVC, mol \% } \\
\text { in monomer }\end{array}$ & $\begin{array}{l}\text { DVC, mol \% } \\
\text { in polymer }\end{array}$ & $\begin{array}{c}1,2 \text {-glycol } \\
(\mathrm{mol} \%)\end{array}$ & $\begin{array}{c}D_{918} \\
D_{849}\end{array}$ & $\begin{array}{c}\nu_{\mathrm{c}-\mathrm{o}} \\
\left(\mathrm{cm}^{-1}\right)\end{array}$ & $\overline{D P}$ & $\begin{array}{c}T_{m} \\
\left({ }^{\circ} \mathrm{C}\right)\end{array}$ \\
\hline 20 & 20.0 & 27.2 & 11.4 & 0.30 & 1090 & 358 & - \\
21 & 50.0 & 55.5 & 19.7 & 0.25 & 1075 & - & - \\
22 & 80.0 & 84.1 & 24.0 & 0.25 & 1060 & 274 & - \\
23 & 100 & 100 & 30.0 & 0.18 & 1060 & - & - \\
24 & 25.0 & - & 12.1 & 0.24 & 1090 & 243 & 207 \\
25 & 50.0 & - & 19.5 & 0.21 & 1075 & 237 & 181 \\
26 & 75.0 & - & 25.6 & 0.22 & 1060 & - & 164 \\
27 & 100 & - & - & 0.18 & 1060 & - & 118 \\
28 & 100 & - & 42.0 & 0.19 & 1050 & 188 & decomp. \\
29 & 100 & - & 45.8 & 0.17 & 1050 & 164 & decomp. \\
\hline
\end{tabular}

Conditions for polymerization in benzene at $60^{\circ} \mathrm{C}$,

No. 20 27: [DVC] $+[\mathrm{VAc}]=2 \mathrm{~mol} / l,[\mathrm{AIBN}]=0.0134 \mathrm{~mol} / \mathrm{l}$,

No. $28:[D V C]=10 \mathrm{vol} \%,[A[B N]=0.075 \mathrm{~mol} / l$

No. $29:[D V C]=5 \mathrm{vol} \%,[A I B N]=0.038 \mathrm{~mol} / l$

トの指標とされている7 IR スペクトルの吸光度比 $D_{916}$ / $D_{819}$ の值が，1，2-グリコール量の増加により減少する㑯 向にある。さらにC-O伸縮の振動とされている $1090 \mathrm{~cm}^{-1}$ の吸收が $1050 \mathrm{~cm}^{-1}$ へ移動することが認められた。さら に 1，2-グリコール量の增加は著しく融点を低下させ, Expt. No. 28，29 では,はっきりした融点は認められ

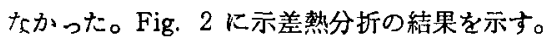

\section{4. 考宾}

Table 2 に見られるように，過ヨウ素酸酸化法による 1，2-グリコール量と，IRスベクトル法によるそれとが 5 員環量の少ない範囲（<15\%) でかなりよい一致を示 している。モデル化合物と考えられるポリェチルビニル

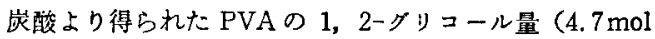
\%) は方貼 PVAのそれ，(3〜4 mol\%）より少し多い程 


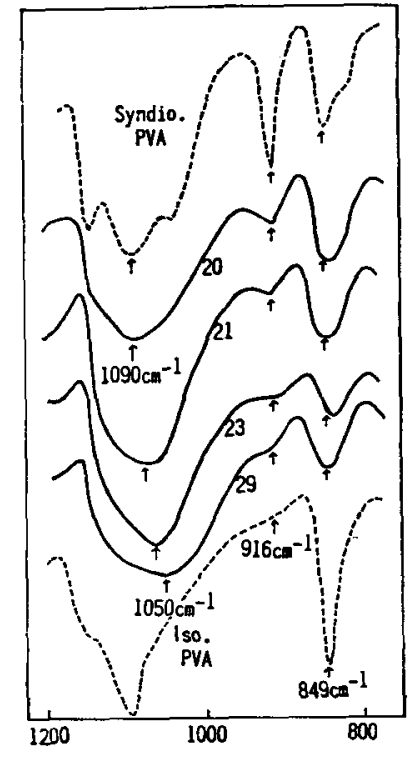

Wave number $\left(\mathrm{cm}^{-1}\right)$

Fig. 1. IR Spectra of PVA containing the 1, 2-glycol structure

度である。すなわら，1，2-ダリコールが主として 5 員 環構造に由来していると思われる。これより，PDVC中 の5賁環榙造の定量に IR スペクトルを用いることは， 少なくとも5員環構造のそれ忹ど多くないとをは妥当 であろう。 5 員環满造の多い場合にずれの大きいこと は, PDVCのIR スベクトル中での 5 員環楧造に由来す る $\nu_{\mathrm{C}=0}$ の $1815 \mathrm{~cm}^{-1}$ の吸取と 6 員環およびペンダントカ ルボナート蓝造に由来する吃=0の $1760 \mathrm{~cm}^{-1}$ の吸収との

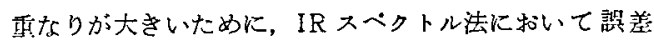
が大きいと考えられる。

Table 3 に芫られるよらに，1，2-グリコール量の変 化により，PVAのIR スペクトル，およびその融点に大 きな変化が㣜められる。

まず，シンジオタクトの指摽とされている，IRスぺ クトルの级光度比 $D_{918} / D_{849}$ の值が，1，2-グリコール量 の增加により減少する傾向が見られる。これはFig. 1 に同時に示しな典型的なイソタクトPVAおよびシンジ オタクトPVAの吸収と比べてみると,特に $849 \mathrm{~cm}^{-1}$ の吸

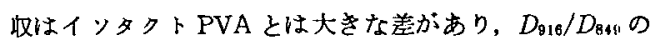

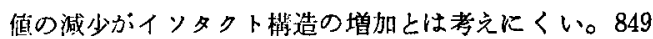
$\mathrm{cm}^{-1}$ の吸収の形はむしろシンジオタクトPVAのそれに 近い。さらに Fig. 1 にあげたシンジォタトPVAが, その PVAc 誘䢙体の NMR スペクトルにより, ヘテロタ クト满造を多く含んでいること（I 6, H 40, S 54)

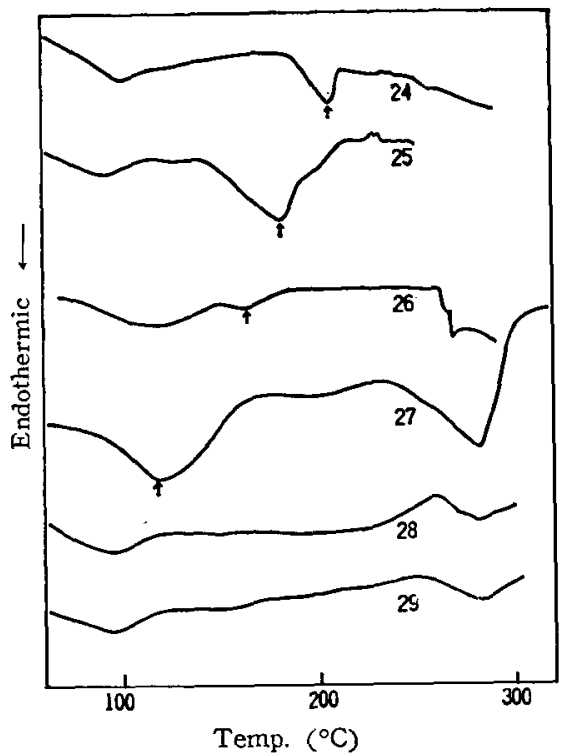

Fig. 2. Thermograms of PVA.

考えあわせると、849 $\mathrm{cm}^{-1}$ の幅庆い㖟収はへテロタクト 構造に㷌因することが予想される。この点に関しては， ざらに検討が必要であるら。

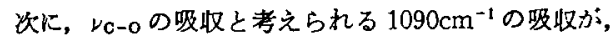
1,2-グリコール铻の増加とともに $1050 \mathrm{~cm}^{-1}$ 入移動して いることが特徽的である。このことは一般に第 2 級フル

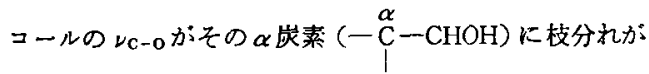
あるとき約 $10 〜 15 \mathrm{~cm}^{-1}$ 低波数側へ移動することが知ら れていること日から，理解され上う。またこの深色移 動が，1，2-ダリコール量が $20 \mathrm{~mol} \%$ を越之るころから 始まるこは興味深い。

1，2-グリコール量が增加するに従い, PVAの融点が 顕著に低下している。これは PVA 中に巽種結合である 1，2-グリコール構造が入ることにより結晶化を妨げて いると考えられる。このことはまた，Fig. 1 に見られ るように，IR スペクトルで結晶化バンドとされている

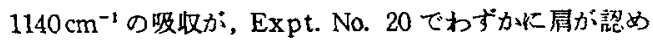
られる程度で，汪とんど消失していることからる推察さ れる。

Flory ${ }^{(0)}$ は結晶化するA単位と結晶化しないB単位と の共重合体において, 次の式洋って, B 単位が A 単位 の融点を低下させることを示している。

$$
\frac{1}{T_{m}}-\frac{1}{T_{m}{ }^{0}}=-\left(\frac{R}{\Delta H_{k}}\right) \ln N_{A}
$$


炭酸ジビニッの重合体より得られるポりビニルフルコールの楧造

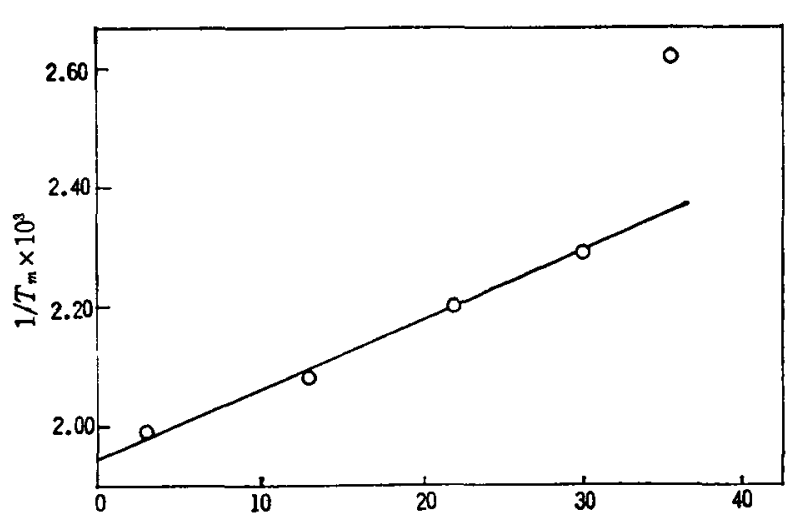

$-\ln N_{A} \times 10^{2}$

Fig. 3. Melting points of PVA plotted according to eq. (4).

ここで, $N_{A}$ はA単位のモル分率、 $T_{m}^{0}$ はA単位のボリ マーの融点, $\Delta H_{\mathrm{u}}$ は融解熱である。

今, 1，2-ダリコール構造を 1，3-グリコール構造から なるPVA中に入った結唱化を乱す共重合物と考皇ると， $N_{A}$ はPVA 中の 1，3-グリンール棈造のモル分富であ ク,1/T $T_{m}$ と一 $\ln N_{A}$ をブロットすれば直線となるはずで ある。このブロットをFig. 3 に示した。右端の点 (Expt. No. 27) を除いて,かなりよい直線関倸がある ことがわかる。Expt. No. 27 の点が值楾よりずれてい る原因としては，一つには，この融点が，Fig，2にみ られるよらにポリマー中に含まれている水の影锌を受け ており、その值に大きな信頼をおけないためとも教えら れる。また, 1、2-グリコールのさらに多い Expt. No. 28,29では，はっきりした融点を認めることができない ことを考えあわせると，1，2-グルコール構造が $30 \%$ 付

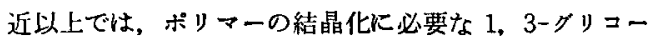
儿連鎖の長さに不足してきて, 結晶化部分が急激に減少 してきたためとも考えられる。この点に関しては、さら に他の方面からの検討が必要であろら。

Fig. 3 の直線部分の勾配から、融解熱 $\Delta H_{u}\left(-\mathrm{CH}_{2}\right.$ $\mathrm{CHOH一}$ 一単位あたり) を求めると $1.67 \mathrm{kcal} / \mathrm{mol}$ となり Tubbs "'が, PVAをグリセロールに稀积して求めた值 $1.64 \mathrm{kcal} / \mathrm{mol}$ とよい一致を示す。また，直線のたて軸に 対する切片から，1，2ークリニールを含まないPVAの融 点 $T_{\mathrm{m}}^{0}$ として $243^{\circ} \mathrm{Cが}$ 求められる。3 4 $\mathrm{mol} \%$ の,2-

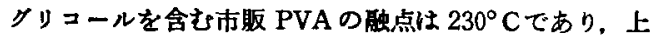

記の值は努当であろう。

以上みてきた結果がら，1２-グリコール構 造の存在は PVA の結晶化に大きな影整を与 えており，その少ない範囲では（ミ25 mol \%)，その増加に比例して結晶化部分を隇少 させると考えられる。また 1,2-グリコール 量が $40 \mathrm{~mol} \%$ を越えると無定形ボリマーを 与える。

付記：示差警分析を报淣いした，合敷 レイヨン株式会社研觉所長, 松本昌一博 士。=チボー峨維研究所長、木津英崔博 士ホボーラログラフの湘定について指導し ていただいた，大阪大学理学部池田重良教 授。稙々の助言をしていたたいた，筑見正 婎博士に染く感謝の意を表します。

なお，内容の一部は，第 12 回高分子研 宪発表会 (1966 年, 神戸) で発表した。

\section{文墄}

1) G.B. Butler, R.J. Angelo: J. Am. Che. Soc., 79, 3128 (1957)

2) S. Murahashi, S. Nozakura, S. Fuji, K. Kikukawa: Bull. Chem. Soc. Japan, 38, 1905 (1965)

3）井本三郎，浮田純二，小南次夫：高化，14。214 (1957)

4) H.E. Harris, J.G. Pritchard: I. Polymer Sci., A 2, 3673 (1964)

5）中島章夫, 古館勝正：高化，6，460（1949）

6）菊川 清，野桜俊一，村橋俊介：高化，24，801 (1967)

7) K. Fujii, T. Mochizuki, S. Imoto, J. Ukida, M. Matsumoto: J. Polymer Sci., A 2, 2327 (1964)

8) S. Murahashi, S. Nozakura, M. Sumi, H. Yuki, K. Hatada: J. Polymer Sci., B 4, 65 (1966)

9) H.H. Zeiss, M. Tsutsui : J. Am. Chem. Soc., 75, 897 (1953)

10) P.J. Flory: J. Chem. Phys., 17, 223 (1949), "Priciples of Polymer Chemistry" 568, Cornell Univ. Press (1953)

11) R.K. Tubbs: J. Polymer Sct., A 3, 4181 (1965) 


\section{I -3}

Cyclopolymerization of Divinyl Esters of Dibasic Acids and Structure of Poly(vinyl alcohol) derived from the Polymers

\section{Synopsis}

Divinyl esters of dibasic acids $\left(\mathrm{CH}_{2}=\mathrm{CHOCO}\left(\mathrm{CH}_{2}\right)_{n-3} \mathrm{COOCH}=\mathrm{CH}_{2}\right.$, $n=2$ - 10) were synthesized and polymerized with radical initiator, and the structure of poly(vinyl alcohol) derived from the polymers were studied. The cyclopolymerizability of these monomers was nearly equall or less than that of divinyl carbonate which was previously reported, and the extent of cyclization was $15 \%-65 \%$. All the monomers yielded gelled polymers. The monomers which are to yield even membered rings tend to cyclopolymerized easier than odd membered rings. Poly(vinyl alcohol) derived from these polymers showed similar structure with respect to $1,2-$ glycol content and stereoregularity to that from poly(vinyl acetate). 


\section{Introduction}

We have previously studied the cyclopolymerizability of divinyl carbonate and the properties of the poly(vinyl alcohol) (PVA) derived from its polymer, and have shown that divinyl carbonate is cyclopolymerized with a radical initiator to give the polymer containing the 5-membered ring in part( 30mol\%), that 1s, the head-to-head type cyclopolymerization occurs $\left.{ }^{1}, 2\right)$. Therefore, PVA derived from poly(divinyl carbonate) by saponification contains a large amount of the 1,2-glycol structure ( $\sim 40 \mathrm{~mol} \%)$ and exhibits different properties from that derived from poly(vinyl acetate). For example, the increase of the 1,2glycol structure lowers the melting point of PVA and deteriorates the crystallinity ${ }^{2}$. Furthermore the 1,2-glycol structure affects violently the PVA-1odine blue color reaction 3,4$)$. It is therefore, of interest to prepare the PVA containing a large amount of the 1,2-glycol structure and to study its properties. For this purpose, divinyl esters of dibasic acids other than divinyl carbonate were studied.

The 5-membered ring structure is formed as well as the 6membered ring in the case of the polymerization od divinyl carbonate $^{l)}$, whereas the 7-membered ring structure is hardly formed compared with the 6-membered ring at the ring closure reaction of low molecular weight compounds ${ }^{5}$ ). Thus, divinyl oxalate may be a suitable monomer for the preparation of the head-to-head linkage in PVA; for the formation of the 6-membered ring(head-to- 
head) competes with that of the 7-membered ring(head-to-tail) In the cyclopolymerization of divinyl oxalate. If the 6-membered ring is formed predominantly, the derived PVA will mainly be comprized of the 1,2-glycol structure. Although Mark claimed such an idea for divinyl oxalate ${ }^{6)}$, the structure of the polymer has not been reported in detail.

In the present paper we have dealt with the synthesis and the polymerization of the divinyl esters of dibasic acids, $\mathrm{CH}_{2}=\mathrm{CHOCO}\left(\mathrm{CH}_{2}\right)_{n-3} \mathrm{COOCH}=\mathrm{CH}_{2}, \mathrm{n}=2 \sim 10$, and have studied their cyclopolymerizability and the property of the PVA derived from the polymers in comparison with the case of divinyl carbonate.

\section{Experimental}

\section{Preparation of Monomers}

Divinyl esters of oxalic, malonic and succinic acid were synthesized by a reaction of mercuridiacetaldehyde w1th the corresponding acid chlorides in ether similarly to the method for divinyl carbonate ${ }^{l}$. A typical reaction condition is described below.

A mixture of $120 \mathrm{~g}$ of mercuridiacetaldehyde, $200 \mathrm{ml}$ of ether and a slight amount of hydroquinone was placed in a 500ml threenecked flask equipped with a reflux condenser with a calcium chloride tube, a stirrer and a dropplng funnel, and the flask 
was cooled with an ice bath. A solution of $27 \mathrm{~g}$ of oxalyl chloride in $45 \mathrm{ml}$ of ether was added to the flask with stirring during half an hour, and stirred for additional one hour at room temperature. The resulting chloromercuriacetaldehyde was removed by filtration and the filtrate was subjected to distillation at reduced pressure. The yield was $18.18,64 \%$ based on oxalyl chloride.

Divinyl esters of glutaric, adipic, pimelic, suberic, azeraic and sebacic acid were synthesized by the well-known transvinylation reaction of acid with an excess of vinyl acetate using mercuric acetate and sufuric acid as catalysts ${ }^{7)}$. A typical reaction condition is described below.

A mixture of $30 \mathrm{~g}$ of adipic acid, $200 \mathrm{ml}$ of vinyl acetate, $\mathrm{g}$ of mercuric acetate, $0.2 \mathrm{ml}$ of sulfuric acid and a slight amount of cupric stearate or copper powder was placed in a 500ml three-necked flask equipped with a reflux condenser with a calcium chloride tube and a mechanical stirrer, and the flask was heated to reflux the reaction mixture with an oil bath. After 10 hours $0.8 \mathrm{~g}$ of sodium acetate was added to the cooled reaction mixture. The excess of vinyl acetate was evaporated by an aspirator at room temperature and the residual solution was distilled at reduced pressure. The yield was $26 \mathrm{~g}, 64 \%$ based on adipic acid.

The results for all the divinyl esters were summerized in Table I. IR and NMR data are shown in Table II. Other materials were purified in the usual way 
Table I. Syntheses of Divinyl Esters

\begin{tabular}{lcccccccc} 
Divinyl & Yleld & b.p. & m.p. & $\mathrm{n}_{\mathrm{D}}^{25}$ & \multicolumn{2}{c}{ Found } & \multicolumn{2}{c}{ Calcd. } \\
Esters & $\%$ & ${ }^{\circ} \mathrm{C} / \mathrm{mmHG}$ & ${ }^{\circ} \mathrm{C}$ & & C & H & C & H
\end{tabular}

$\begin{array}{lllllllll}\text { Oxalate } & 64 & 81.8 & 23.0 & 1.4460 & 49.90 & 4.17 & 50.71 & 4.26\end{array}$ $\sim 82 / 45 \sim 23.5$

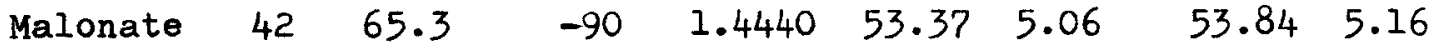
$\sim 65.5 / 6 \sim-100$

Succinate $68 \quad 50 / 3 \quad 25.0 \quad 1.4477$ $\sim 25.5$

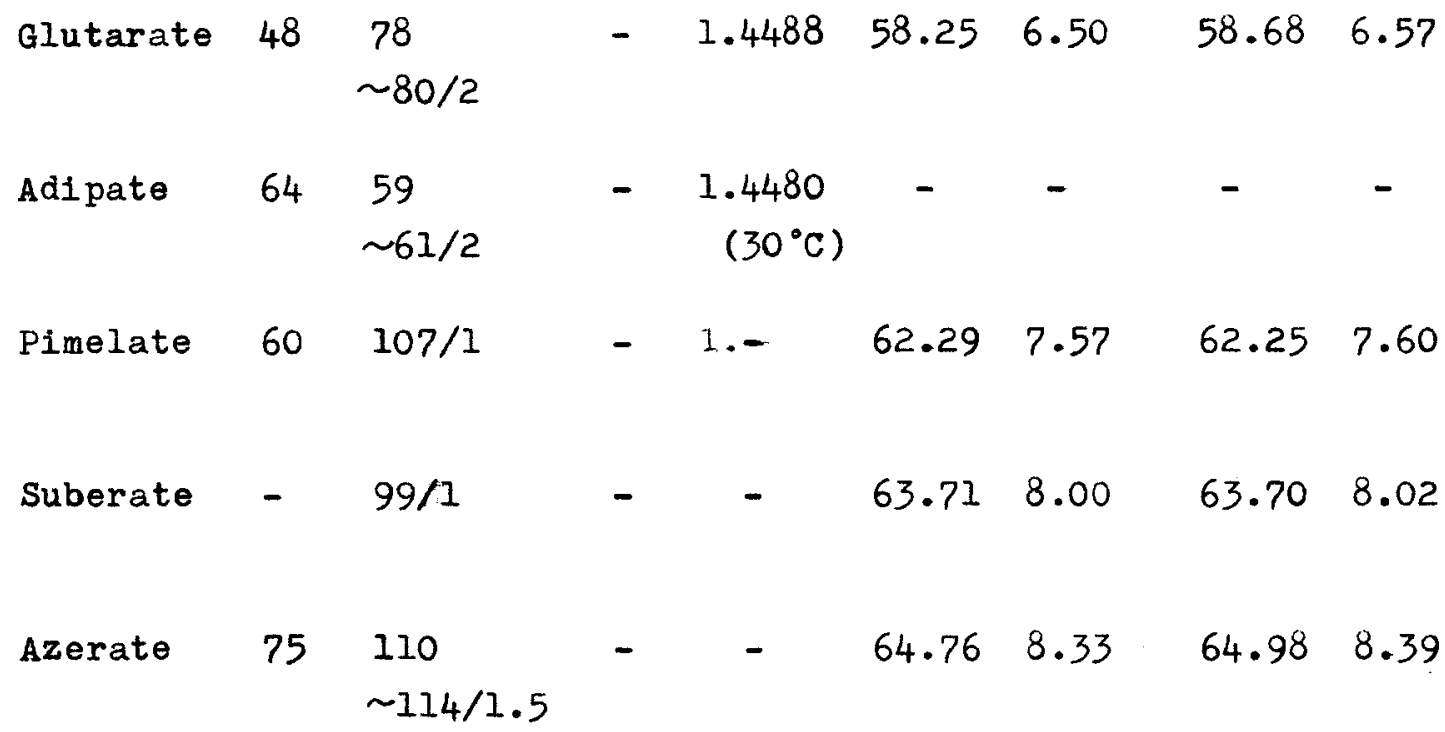

$\begin{array}{lllllllll}\text { Sebacate } & 66 & 141 & 7 \sim 8 & 1.4521 & 65.79 & 8.65 & 66.12 & 8.72\end{array}$ $\sim 145 / 3$ 
Table II. Spectroscopic Data of Divinyl Esters

Divinyl Infrared spectra, $\mathrm{cm}^{-1} \quad$ NMR spectra, $J$, a)

Esters

$\nu_{c=0} \quad \nu_{c=c}$

$\mathrm{H}_{2}$

$\mathrm{H}_{2}$

$\mathrm{H}_{3}$

\begin{tabular}{|c|c|c|c|c|c|}
\hline Carbonate & 1775 & 1660 & 2.85 & 5.00 & 5.35 \\
\hline Oxalate & $\left\{\begin{array}{l}1764 \\
1790\end{array}\right.$ & 1651 & 3.15 & $5 \cdot 30$ & 5.54 \\
\hline Malonate & $\left\{\begin{array}{l}1752 \\
1770\end{array}\right.$ & 1650 & 2.73 & 5.08 & 5.38 \\
\hline Succinate & 1760 & 1650 & 2.71 & 5.12 & $5 \cdot 38$ \\
\hline Glutarate & 1760 & 1650 & 2.72 & 5.17 & 5.43 \\
\hline Adipate & 1760 & 1650 & 2.72 & 5.18 & 5.48 \\
\hline Pimelate & 1763 & 1650 & - & - & - \\
\hline Suberate & 1762 & 1650 & - & - & - \\
\hline Azerate & 1763 & 1650 & - & - & - \\
\hline Sebacate & 1760 & 1650 & 2.72 & 5.20 & 5.50 \\
\hline
\end{tabular}

a) $\mathrm{H}_{1}, \mathrm{H}_{2}$ and $\mathrm{H}_{3}$ represent vinylic proton, $\mathrm{H}_{3}$<smiles>C=COC</smiles>

The esters were examined as 10vol\% solutions in carbon tetrachloride and the chemical shifts were measured from tetramethylsilane internal reference. 


\section{Polymerization Frocedure}

An ampoule containing a monomer, benzene and $2,2^{\prime}$-azobisisobutyronitrile(AIBN) was degassed three times by the freezethaw method, and then sealed under vacuum $\left(\sim 10^{-3} \mathrm{mmHg}\right)$. Polymerization was carried out in a thermostat at $60 \pm 0.005^{\circ} \mathrm{C}$. The polymerization mixture, which almost gelled, was poured into a large amount of petroleum ether, yielding a precipitate of polymer. The polymer was washed several times with petroleum ether by decantation and separated by centrifugation and then ciried at room temperature under vacuum. The conversion was determined gravimetrically. For the determination of the rate of polymerization and of the extent of cyclization, a condition of $10 \mathrm{ml}$ benzene solution of $0.5 \mathrm{~mol} / 1$ monomer and $0.005 \mathrm{~mol} / 1$ AIBN was used.

\section{Extent of Cyclization}

The extent of cyclization was calculated from the content of residual double bonds in polymer extraporated to $0 \%$ converston in order to exclude the effect of the monomer concentration change from progress of the polymerization. The residual double bond was calculated from the absorbance ratio, $D_{c=c} / D_{c=0}$, of the IR spectrum(nujol mull), assuming that the absorption coefficients of $D_{c=c}$ and $D_{c=0}$ in monomer and polymer are identical. The extraporation to $0 \%$ conversion was shown in Figure 1 . Because of this ussumption and of the neglect of consumption of double bond other than cyclization such as branching, the extent of 


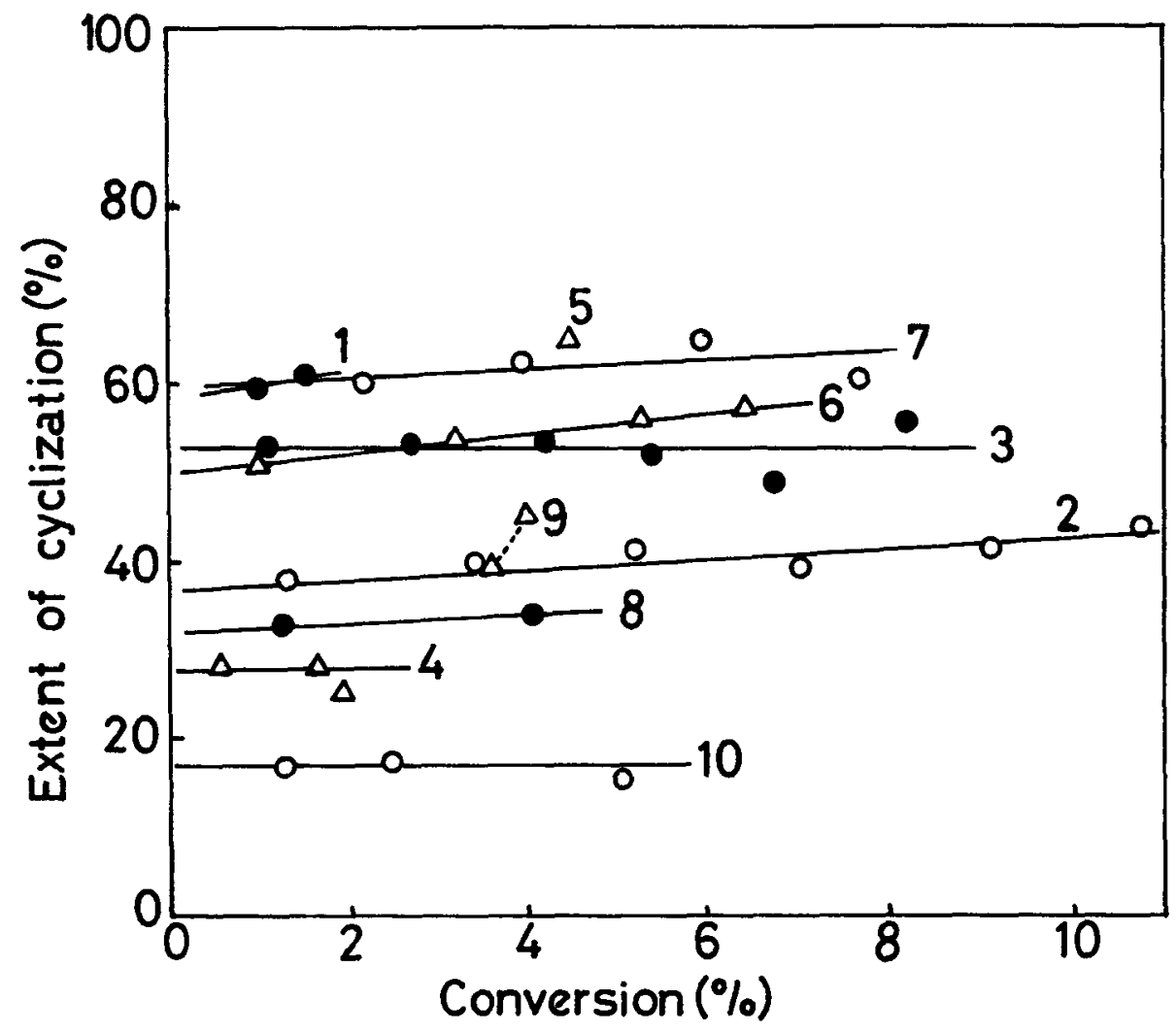

Flgure 1. Brtraporation of Extents of Cyclization to $0 \%$ Conversion in Radical Polymerization of Divinyl Esters

Polymerization conditions; $[M]=0.50 \mathrm{~mol} / 1$, $\left[\right.$ AIBN] $=0.0050 \mathrm{ml} / 1$ in benzene solution at $60^{\circ} \mathrm{C}$ $\left(\mathrm{CH}_{2}=\mathrm{CHOCO}\right)_{2}\left(\mathrm{CH}_{2}\right)_{n-2}$, where $n=1$ represents divinyl carbonate. 
cyclization calculated here night include a considerable error. Thus, these data might be a reasonable measure of the extent of cyclization as far as howologous monomers are concerned.

\section{Saponification of Polymer}

$20 m$ of a $10 \%$ aqueous potassium hydroxide solution was added to $1 \mathrm{~g}$ of swelled polymer in $20 \mathrm{ml}$ of acetone. Saponification was completed for a day at room tenperature. After separation of inorganic ion and low molecular weight compounds by dialysis, an aqueous polymer solution was poured into a large amount of methanol, yielding a precipitate of PVA. The PVA was dried by freezearying of an aqueous solution.

\section{Characterization of PVA}

1,2-Glycol content was determined by titrating the periodic acid consuinption by PVA in accordance with the method of Harris et al. 8 )

Degree of polymerization of PVA was calculated from a specific viscosity of a $1 \%$ aqueous PVA solution according to the equation presented by Nakajina 9 ).

IR spectrum of PVA was measured with a film which was prepared from a $1 \%$ aqueous solution and dried at $30^{\circ} \mathrm{C}$ in a silicagel desiccator. 


\section{Results and Discussion}

\section{Rate of Polymerization}

The time-conversion curves of the polymerization of divinyl esters at $0.50 \mathrm{~mol} / 1$ benzene solution are shown in Figure 2 and the rate of polymerization are given in Table III. Figure 3 shows the rate of polymerization of each monomer, representing a periodical relationship with the methylene numbers of the monomers. Since therewas no correlation to the extent of cyclization, this periodical properties in the rate of polymerization sould be ascribed to the reactivity of the vinyl group in each monomer. If the main factor of this property is the inductive effect of substituents, $\mathrm{CH}_{2}=\mathrm{CHOCO}\left(\mathrm{CH}_{2}\right)_{n-2} \mathrm{COO}-$, such variation in the rate of polymerization is not expected for the change from divinyl succinate to divinyl sebacate $(n=4 \sim 10)$. Actually the spectroscopic data for the monomers, $n=4 \sim 10$, showed a similar property of the vinyl group to one another and to vinyl acetate (Table II). The reason for this periodical property of the rate of polymerization is not yet explainable.

The plot of the extent of cyclization against the rate of polymerization is de tcted in Figure 4. There seems to be two groups of monomers, one is comparatively likely to cyclize and the other is not. In each eroup, the increase of the polymerizability is accompanied by the decrease in the extent of cyclization. 


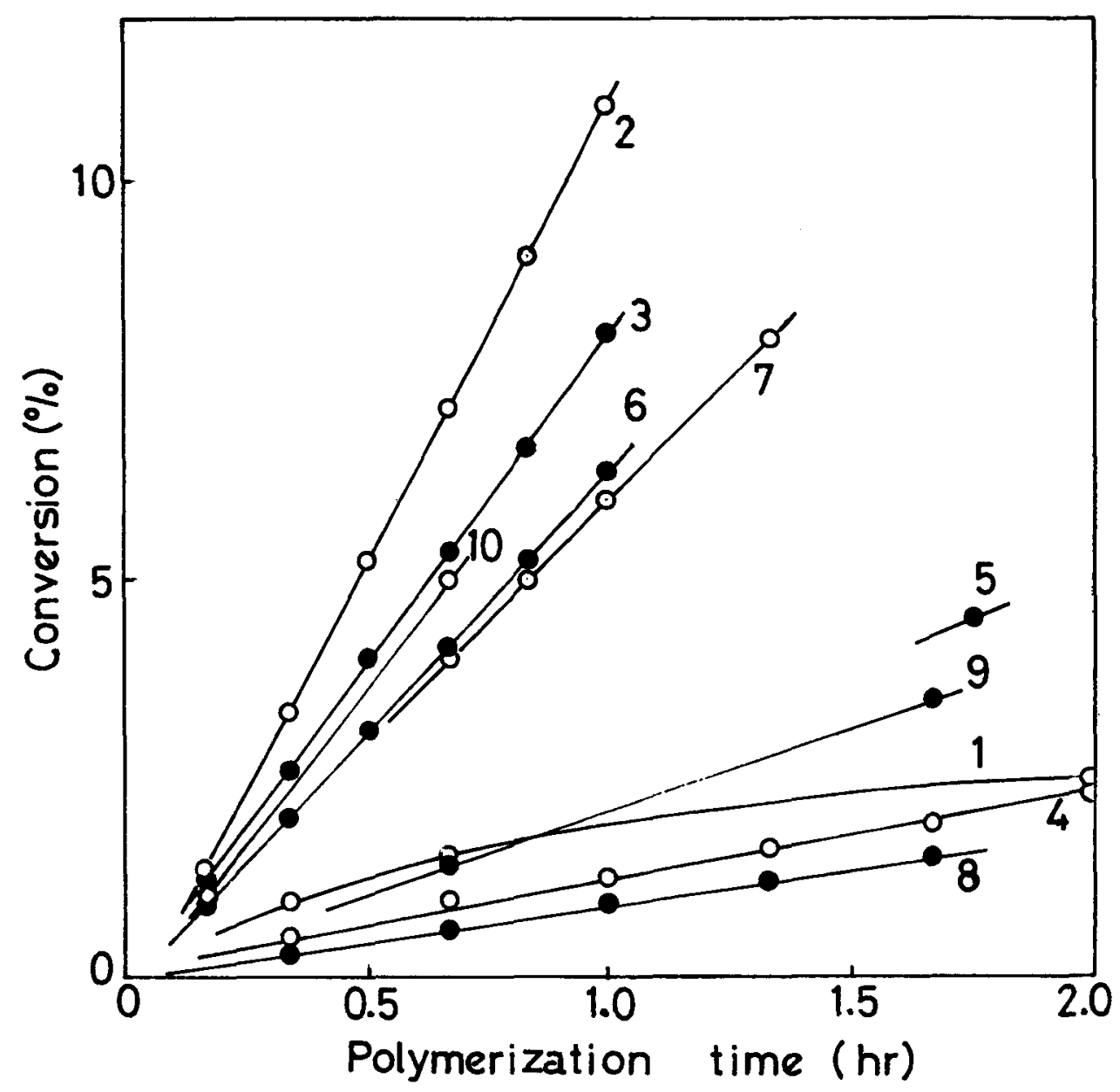

Figure 2. Tine-Conversion Curves at Polymerization of Divnyl Esters

Polymerization condition is identical to those described in Figure 1.

$\left(\mathrm{CH}_{2}=\mathrm{CHOCO}\right)_{2}\left(\mathrm{CH}_{2}\right)_{n-2}$, where $\mathrm{n}=1$ represents divinyl carbonate. 


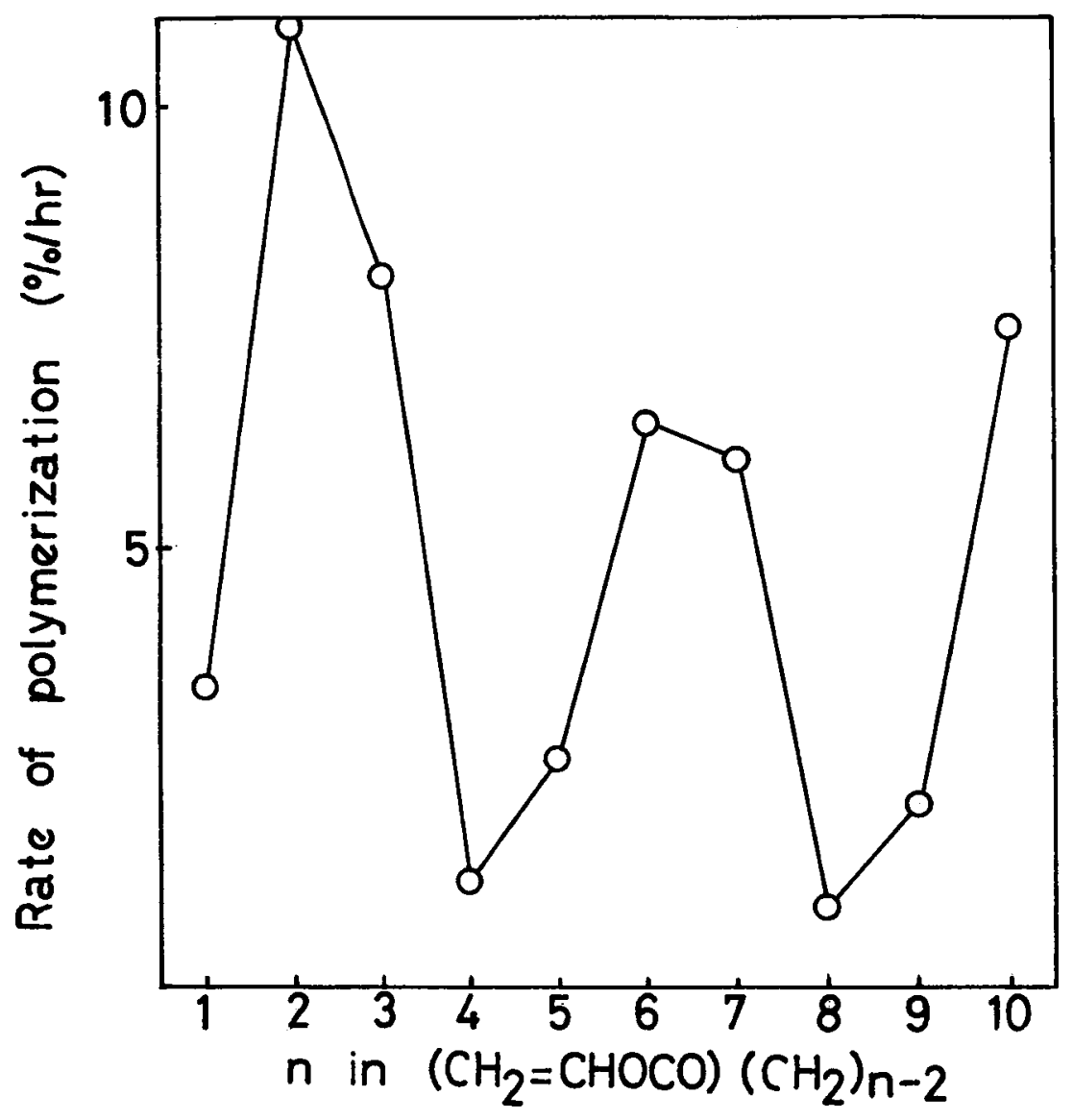

Figure 3. Rate of Polymerization of Divinyl Esters $\left(\mathrm{CH}_{2}=\mathrm{CHOCO}\right)_{2}\left(\mathrm{CH}_{2}\right)_{n-2}$, where $\mathrm{n}=1$ represents divinyl carbonate. 
Table III. Rate of Polymerization and Extent of Cyclization

Polymerization condition; $[M]=0.50 \mathrm{~mol} / 1, \quad[$ AIBN] $=0.0050 \mathrm{~mol} / 1$ in benzene solution at $60^{\circ} \mathrm{C}$

Monomer $\quad R_{p}(\% / h r) \quad$ Extent of Cyclization

D.V. Carbonate

3.4

59

D.V. Oxalate

10.9

37

D.V. Malonate

8.1

63

D.V. Succinate

1.3

28

D.V. Glutarate

2.6

65

D.V. Adipate

6.4

50

D.V. Pimelate

6.0

60

D.V. Suberate

0.9

32

D.V. Azerate

2.1

42

D.V. Sebacate

$7 \cdot 5$

17 


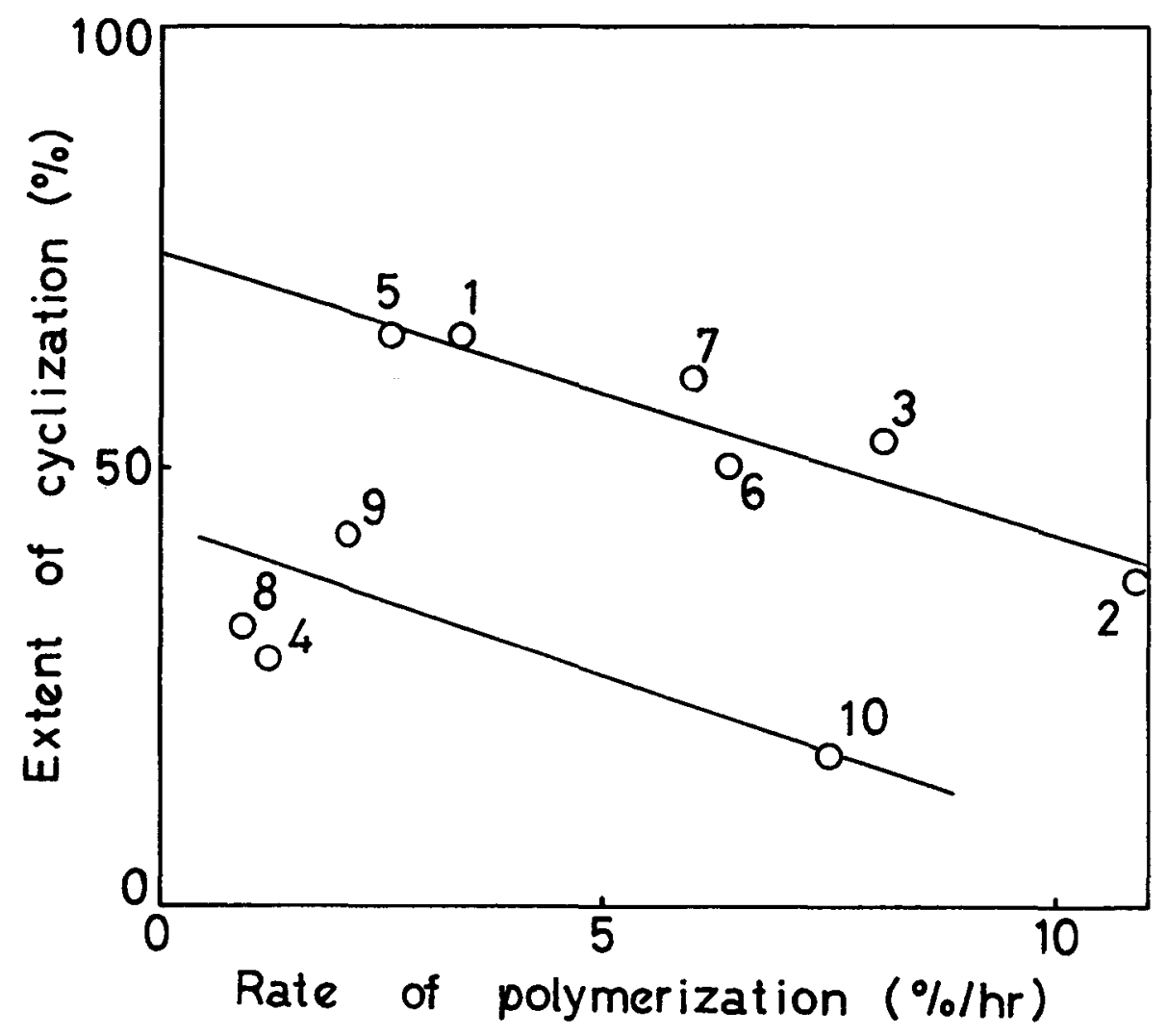

Figure 4. Correlation between Rate of Polymerization and Extent of Cyclization 


\section{Extent of Cyclization}

The structure of the cyclic units in polymers is considered to be almost the head-to-tail type judging from the content of the 1,2-glycol structure in FVA described afterward. The extents of cyclization are given in Table III. Figure 5 shows an alternation of the extents of cyclization as in the melting point of dibasic acids. Although the accuracy of the absolute value of these data was not so good as described before, it is a very interesting correlation. The conformation of the monomers in solution and the stability of cyclic unit should be considered in rationalization of the alternation tendency. Dipole moment, which is considered as a measure of the conformation in solution, of diethyl esters of dibasic acids are similar to each other except for carbonate, oxalate and succinate ${ }^{10}$ ? The stability of the ring structure has not yet been known. A similar tendency of the ease of cyclization of diallyl esters of dibasic acids was expected because the structure of ring in poly(diallyl esters) resembles that in poly(divinyl esters). However, the result of bulk polymerization of diallyl esters, which was reported by Simpson and Holt and 1 s shown in Figure $5^{11}$, did not resemble that of divinyl esters.

Marvel et al. reported the cyclopolymerization of $\alpha$-diolefins, $\mathrm{CH}_{2}=\mathrm{CH}\left(\mathrm{CH}_{2}\right)_{n} \mathrm{CH}=\mathrm{CH}_{2}, \mathrm{n}=2 \sim 15$, with the ziegler catalyst, $\mathrm{Al}(1-\mathrm{Bu})_{3}^{-}$ $\mathrm{PiCl}_{4}$, and the result is shown in Figure $5^{12}$. In the cyclopolymerization of $\alpha$-diolefins, the ease of cyclization at 5 and 6 


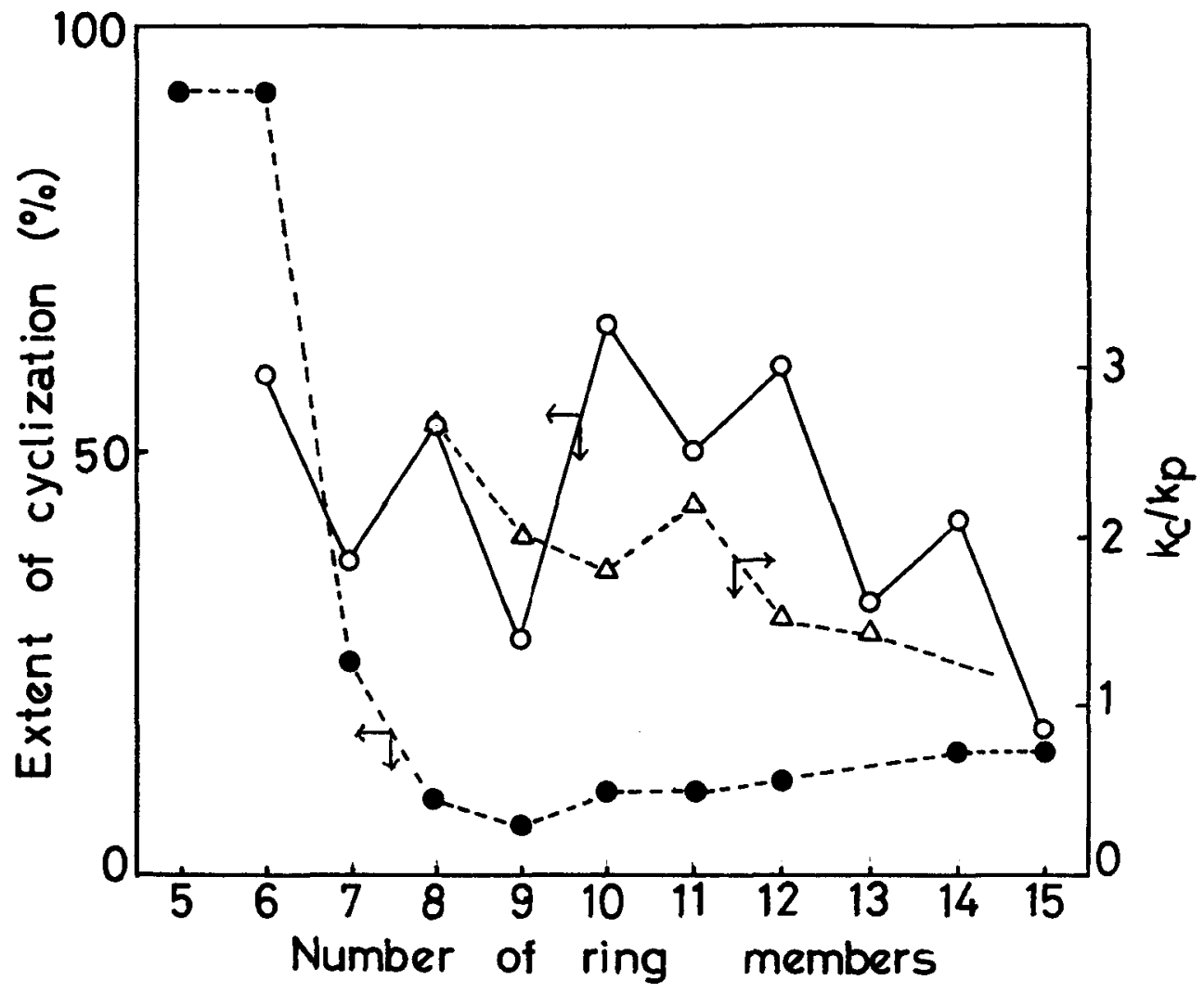

Figure 5. Extent of Cyclization in the Radical

Polymerization of Divinyl Esters

O; Divinyl esters, polymerization condition is identical to those described in Figure 1.

-; -Diolefins, $\mathrm{M} 0.20 \mathrm{~mol} / 1$, catalyst, $\mathrm{Al}(i-B u)_{3}-$ $\mathrm{T} \mathrm{Cl}_{4}{ }^{12)}$

$\Delta$; Diallyl esters, bulk polymerization at $30^{\circ} \mathrm{C}$ catalyst, benzoyl peroxide, II) 
membered rings are explicable on the basis of the ring strain. On the other hand, there appeares to be not so great différence in the ring strain beween divinyl carbonate and other divinyl esters. Two methylene groups in poly ( $\alpha$-diolefins) are replaced by two oxygen atoms in poly(divinyl esters) and this replacement may releave steric interference, that is, it increase the ease of cyclization.

\section{Structure and Properties of derived PVA}

The properties of the PVA which was derived from the poly(divinyl esters) by saponification are given in Table IV along with the polymerization conditions. All the monomer were liable to form gelled polymers corresponding to medium cyclopolymerizability. The derived PVA showed a closely similar structure with respect to the $1,2-g l y c o l$ content and stereoregularity to that from poly(vinyl acetute). As to PVA derived from poly(divinyl oxalate), it seemed likely that 1,2-glycol structure should be formed considerably if the formation of the 6-membered ring with the head-to-head linkage is preferentially expected in poly(divinyl oxalate). No difference, however, could be detected between PVA from poly(divinyl oxalate) and those from other poly(divinyl esters). Since a considerable cyclization occured as previously described, the ring closure reaction in divinyl oxalate should have yielded the 7-membered ring predominintly. This results showed that the ease of cyclization does not depend only 
Table IV. PVA derived from Poly(divinyl esters)

[M] Polymn. Conv.

Derived PVA

$\begin{array}{ccllll}\text { Monomer vol\% } & \begin{array}{c}\text { time } \\ \mathrm{hr}\end{array} & \% & \mathrm{D}_{916} & \begin{array}{l}1,2-\text { glycol } \\ \mathrm{D}_{849}\end{array} & \text { content, } \%\end{array}$

\begin{tabular}{|c|c|c|c|c|c|c|}
\hline Divinyl a) & 100 & 0.25 & 9.9 & 631 & 0.30 & 13.7 \\
\hline \multirow{2}{*}{ Carbonate } & 10 & 67 & - & 188 & 0.19 & 42.0 \\
\hline & 5 & 67 & 30 & 164 & 0.17 & 45.8 \\
\hline Divinyl & 20 & 4 & 80 & 525 & 0.26 & 3.4 \\
\hline \multirow{2}{*}{ Oxalate } & 10 & 2 & 29 & - & 0.23 & 2.7 \\
\hline & 1 & 50 & 54 & 132 & - & 3.2 \\
\hline Divinyl & 20 & 16.3 & 91 & 182 & 0.26 & $4 \cdot 3$ \\
\hline \multirow{2}{*}{ Malonate } & 10 & 2 & 44 & - & 0.26 & 4.2 \\
\hline & 1 & 50 & 34 & - & - & - \\
\hline Divinyl & 20 & 4 & 72 & 218 & 0.23 & 3.6 \\
\hline \multirow{2}{*}{ Succinate } & 10 & 20 & 91 & 150 & 0.27 & 4.1 \\
\hline & 11 & 50 & 41 & - & - & - \\
\hline Divinyl & 20 & 15 & 84 & 201 & 0.39 & 3.6 \\
\hline \multirow{2}{*}{ Glutarate } & 10 & 20 & 74 & 138 & - & 3.9 \\
\hline & 1 & 50 & 35 & - & - & - \\
\hline Divinyl & 20 & 10 & 83 & 180 & 0.36 & 3.7 \\
\hline \multirow{2}{*}{ Adipate } & 10 & 20 & 80 & - & 0.39 & 3.6 \\
\hline & 1 & 50 & 41 & - & - & - \\
\hline Divinyl & 20 & 15 & 83 & 194 & 0.41 & 3.8 \\
\hline \multirow[t]{2}{*}{ Sebacate } & 10 & 24 & 55 & 163 & - & $4 \cdot 6$ \\
\hline & 1 & 50 & 17 & - & - & - \\
\hline
\end{tabular}

a) The data is cited from reference (2), and reaction condition was similar to this paper. 
on number of ring atoms. Frobably divinyl oxalate has a particular conformation which is unfavorable to produce the 6-membered ring owing to the presence of neighboring two carbonyl groups.

Mizushima reported from spectroscopic measurement that two conformations occur in the case of oxalic acid derivatives, a trans and a cis form ${ }^{13)}$. Ketelaar and Meurs reported the energy difference getween both conformations to be $420 \mathrm{cal} / \mathrm{mol}$ for ethyl oxalate from the measure of temperature dependency of dipole moment ${ }^{14}$ ). Construction of the model of the 6-membered ring shows that two carbonyl groups are roughly parallel to each other taking a cis conformation, whereas the carbonyl group in 7membered ring are roughly perpendicular to one another. Therefore, the formation of the 6-membered ring may require higher activation energy than the 7-membered ring. For this reason, the 6-membered ring hardly formed in the polymerization of divinyl oxalate.

Optical density ratio, $D_{916} / D_{849}$, of the IR spectrum of PVA is considered to be a measure of tacticity in case of low content of $1,2-g 1 y c o l$ structure. The ratio showed that PVAs from poly(divinyl oxalate), malonate and succinate possess slightly higher isotactic structure than PVAs from other polymers. This result suggests that the some steric control which is probably attributed to the strained conformation of the cyclized free radical during the cyclopolymerization process of these three monomers. Whereas, the large membered ring have little ring strain and then have little steric control for the cyclopolymerization of other monomers. 


\section{References}

1. S. Murahashi, S. Nozakura, S. Fuji and K. Kikukawa, Bull. Chem. Soc. Japan, 38, 1905(1965)

2. K. Kikukawa, S. Nozakura and S. Murahashi, Kobunshi Kagaku, 25, 19(1968)

3. J. Shibatani, M. Nakamura and Y. Oyanagi, Kobunshi Kagaku, 26, $118(1969)$

4. K. Kikukawa, S. Nozakura and S. Murahashi, Polymer J., in press

5. M. Stoll and A. Rouve, Helv. Chim. Acta, 18, 1087 (1935) E. W. Spanagel and W. H. Carothers, J. Am. Chem. Soc., 57, $929(1935)$

6. H. F. Mark, U. S. Patent, 3,081,282(1963)

7. R. L. Adelman, J. Or8. Chem., 14, 1057(1949)

8. H. E. Harris and J. G. Pritchard, J. Polym. Sci., A2, 3673(1961)

9. A. Nakajima and K. Furudate, Kobunshi Kagaku, 6, 460 (1949)

10. Landolt-Börnstein,"Zahlenwerte und Funktionen aus Physik, Chemie, Astromonie, Geophysik und Technik" 6 Auf., I Band, 3 Teil (Springer-Verlas, Berlin, 1951) p.415

11. T. Holt and W. Simpson, Proc. Roy. Soc.(London), A238, 154(1956)

12: C. S. Marvel and W. E. Farrison, J. Am. Chem. Soc., 81, 4737(1959)

13. S. Mizushima, "Internal Rotation and Molecular Configuration" (Academic Press, New York, 1954)

14. J.A.A. Ketelaar and N. van Meurs, Rec. trav. chim., 26, 495(1957) 


$$
\mathrm{I}-4
$$

Copolymerization of Divinyl Carbonate

\section{Synops is}

Copolymerization parameters of divinyl carbonate were determined by the copolymerization with p-chlorostyrene and vinyl acetate, and compared with those of ethyl vinyl carbonate. $Q$ and $\underline{e}$ values are: $\underline{Q}=0.035, \underline{e}=-0.23$ for divinyl carbonate and $\underline{Q}=0.025, \underline{e}=-0.26$ for ethyl vinyl carbonate. These values suggest that copolymerization reactivities of divinyl carbonate and ethyl vinyl carbonate are alike each other and are close to that of vinyl acetate $(Q=0.026$, $\underline{e}=-0.22)$. Since divinyl carbonate undergoes a cyclization polymerization to considerable extents, the data also suggest that there is no extraordinary effect of the cyclization on copolymerization parameters. Extent of cyclization of divinyl carbonate was found to be lower in the divinyl carbonate-p-chlorostyrene copolymer than in the divinyl carbonate-vinyl acetate copolymer. 


\title{
〔112〕炭酸ジビニルの共重合
}

(1967 作: 6 月 27 日受理)

\author{
菊川 清* ·野兴俊一* ${ }^{*}$ 村橋俊介*
}

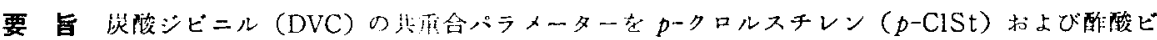

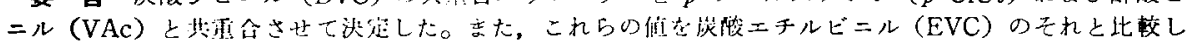
た。Q,e值は各\&, DVCについて, $Q=0.035, e=-0.23$, EVCについて, $Q=0.025, e=-0.26$

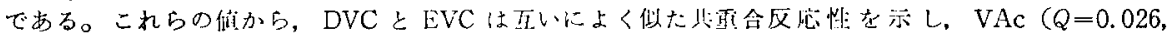

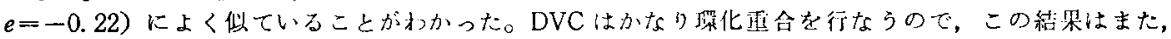

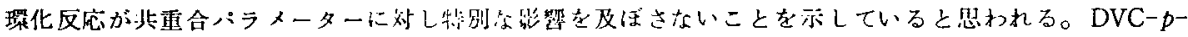

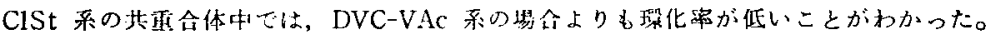

\section{1. 緒 言}

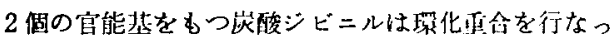
て，環状榄造をるつポリマーを得る可能性がある。さら にその抈水分解に上り得られる PVA は環状㨫造に由米 する特暴な化学權造および立体槛造を期待することがで

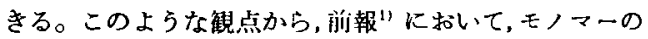

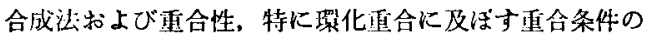
影愁を梌徼した。すなわち，笑酸ジビニルはラジカル重

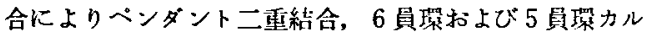
ボナートの3 種の撕造単位からなるポりマーを生成する ことを推定した。重合温度によりこれら槛拈単位間の相 対裂は著しく変化するが, 重合渠, 溶媒の变化によって はポリマー擈造に大きな变化は見られなかった。

本報では，岸酸ジビニルの一般的重合性を知るために 共重合を行なって共重合バラメーター，Q，e 值を求め た。相手モノーとしては，ボリーの維成分析の容易 な $p$ クロルスチレン，执よび反応性のよく似ていると 思われる酢酸ビニルを選んだ。

さらに炭酸ジビニルに打いて同一分子中に 2 保のビ二 ル基があるための効果をみるために，焱酸エチルビニル の尖重合反応性を調べ比較した。

\section{2. 突験}

\section{1 モノマー, 溶媒}

矣酸ジビニルは前報に記したようにホスゲンと办銀シ アセトアルデヒドより合成しだ。 bp $44.7 \sim 45.3^{\circ} \mathrm{C} /$ $85 \mathrm{mmHg}$ 。

炭酸エチルビニルはメチルクロルカルボナートと桹 ジフセトフルデヒドより同様に合成した。bp $69.5^{\circ} \mathrm{C} /$ $147 \mathrm{mmHg}\left(108.5 \sim 108.6^{\circ} \mathrm{C}\right)$

p-クロルスチレンは $p$-クロルアセトフェノンを $\operatorname{Al}(i$ -PrO) ${ }_{3}$ により迮元し, 活性アルミナを用いて熱分解脱

\footnotetext{
* 大阪大学理学部高分子学科（大阪府豊中市待兼山町
} $1 の 1$ )
水して得た。 bp $35.0 \sim 35.2^{\circ} \mathrm{C} / 3 \mathrm{mmHg}$ 。

酶酸ビニルは市服品を $\mathrm{NaHSO}_{3}$ 水溶液で洗浄し，さ らに水洗して, $\mathrm{CaCl}_{2}$ て葫燥後, Widmer の蒸留塔で棐 留した。bp $72.3^{\circ} \mathrm{C}$ 。

モノマーはすべてガスクロマトグラフ（TCPカラム）

により不純物のないことを確かめて用いた。

ベンゼンは常法により精製した。アセトンは $\mathrm{KMnO}_{2}$ を加え， 1 昼夜加熱僄流後，蒸留して用いた。

2.2 共 重 合

岑酸ジ゙ニルは 2 官能基をむつモノマーであるので, モノマー1分子を 2 当量として以下の実験を行なった。

ガラスアンプルヘ所定のモ,マー濃度のベンゼン溶液 をピペットで仕込み（岸酸エチルビニルーp-クロルスチ レン系のみ塊重合) 真空系 $\left(<10^{-3} \mathrm{mmHg}\right)$ で 3 回脱気し た俊、封管し， $60 \pm 0.05^{\circ} \mathrm{C}$ の恒洫慒で静篟重合した。 所定の時間重合した重合溶液を大量の沈版詴(炭酸ジ ニルーp-クロルスチレン系ではメタノール，他はn-へキ サンまたは石油ェーテル) へ注ぎ，数回の decantation をくり返したのち，荻酸ジビニルの系では有機溶媒にホ

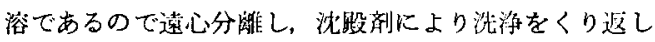

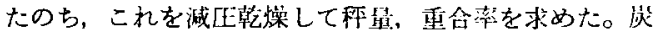
酸エチルビニルの系では, ポリマーをベンゼンに浴か

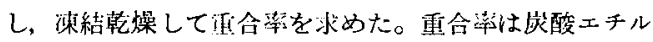
ビニルー酶酸ビニルの系以外は $10 \%$ 以下にとどめた。炎 酸エチルビニルー䣫酸ビニルの采ではわずかに $10 \%$ をこ えたが,モノマー利成とポリマー組成との間にほとんど 差がないので，共重合組成式の微分式をそのまま用い た。

\section{3 共重合体の組成分析}

pークロルスチレンの共重合系では，ポりマー中の壏素 の元䋕分析より，ポリマー中の $p^{-ク ロ ル ス チ レ ン の モ ~}$ ル分率を求めた。酢酸ビニルの共重合采では，ボリマー のアセトン溶液（炭酸ジビニルの多いポリマーでは不溶 部があるが，加水分解に影㹕はない）にカセイソーダ水 溶液を加兄て加水分解し，生じた醀酸ソーダを過剩の筀 


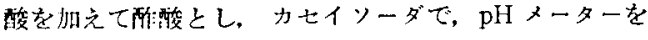
用いて中和鲬定した。これよりボリマー中の酢酸ビニル のモル分深求めた。

\section{4 共重合体の IR スペクトル}

炭酸ジ゙ニルの垬任合矛より得られるポリマーはフィ

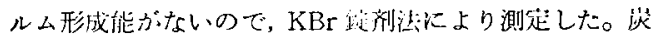
酸エチルビニルの系ではフィルムにより测定した。

\section{3. 結 果}

共重合科夥を Table 1〜4 亿示した。

\section{1 モノマー反応性比 $r_{1}, r_{2}$}

$r_{1}, r_{2}$ の没䇥には Fineman-Ross 法, および交点法 を用いたが，p-クロルスチレンー苂酸ジ゙ニルの系では， Fineman-Ross 法上り求めた $r_{1} ， r_{2}$ 上り得られる其者合 組成曲線が找測侹とかなりずれたので，曲線合致法によ り求めた。それらの仯を本とめて Table 5 に示した。

Table 1. Copolymerization of p-chlorostyrene $\left(\mathrm{M}_{1}\right)$ and divinyl carbonate $\left(\mathrm{M}_{2}\right)$.

$\left[\mathrm{M}_{1}\right]+\left[\mathrm{M}_{2}\right]=2 \mathrm{~mol} / l$ in benzene,

$[\mathrm{AIBN}]=0.01 \mathrm{~mol} / l, 60^{\circ} \mathrm{C}$

\begin{tabular}{c|l|c|c|c}
\hline $\begin{array}{l}\text { Expt. } \\
\text { No. }\end{array}$ & $\begin{array}{l}\mathrm{M}_{2} \text { mole } \\
\text { fraction } \\
\text { in } \\
\text { monomer }\end{array}$ & $\begin{array}{c}\text { Poly- } \\
\text { merization } \\
\text { time } \\
(\mathrm{hr})\end{array}$ & $\begin{array}{c}\text { Con- } \\
\text { version } \\
(\%)\end{array}$ & $\begin{array}{l}\text { M.: mole } \\
\text { fraction } \\
\text { in }\end{array}$ \\
\hline 1 & 0.952 & 45.0 & 2.73 & polymer \\
2 & 0.900 & 22.5 & 6.00 & 0.436 \\
3 & 0.700 & 7.0 & 7.92 & 0.083 \\
4 & 0.600 & 5.0 & 7.40 & 0.053 \\
5 & 0.400 & 3.0 & 6.47 & 0.020 \\
6 & 0.200 & 2.0 & 5.47 & 0.017 \\
\hline
\end{tabular}

Table 2. Copolymerization of vinyl acetate $\left(\mathrm{M}_{1}\right)$ and diviny! carbonate $\left(\mathrm{M}_{2}\right)$.

$\left[\mathrm{M}_{1}\right]+\left[\mathrm{M}_{2}\right]=2 \mathrm{~mol} / \mathrm{l}$ in benzene, $[A I B N]=0.01 \mathrm{~mol} / l, 60^{\circ} \mathrm{C}$

\begin{tabular}{c|l|c|c|c}
\hline \hline Expt. & $\begin{array}{l}\text { M.: mole } \\
\text { fraction } \\
\text { No. }\end{array}$ & $\begin{array}{c}\text { Poly- } \\
\text { in } \\
\text { monization }\end{array}$ & $\begin{array}{c}\text { Con. } \\
\text { version } \\
(\%)\end{array}$ & $\begin{array}{l}\text { M.: mole } \\
\text { fraction } \\
\text { in }\end{array}$ \\
\hline 7 & 0.100 & 2.5 & 9.16 & 0.126 \\
8 & 0.300 & 2.5 & 8.07 & 0.359 \\
9 & 0.500 & 2.5 & 6.67 & 0.567 \\
10 & 0.600 & 2.5 & 6.99 & 0.668 \\
11 & 0.700 & 2.5 & 6.76 & 0.746 \\
12 & 0.900 & 2.5 & 5.97 & 0.839 \\
13 & 0.506 & 2.0 & 4.13 & 0.572 \\
\hline
\end{tabular}

Table 3. Bulk copolymerization of p-chloro styrene $\left(\mathrm{M}_{1}\right)$ and ethyl vinyl carbonate $\left(\mathrm{M}_{2}\right)$.

[AIBN] $=0.5 \mathrm{~mol} \% /$ monomer, $60^{\circ} \mathrm{C}$

\begin{tabular}{|c|c|c|c|c|}
\hline $\begin{array}{l}\text { Expt. } \\
\text { No. }\end{array}$ & $\begin{array}{l}\mathrm{M}_{2} \text { mole } \\
\text { fraction } \\
\text { in } \\
\text { monomer }\end{array}$ & $\begin{array}{l}\text { Poly- } \\
\text { merization } \\
\text { tinje } \\
\text { (hr) }\end{array}$ & $\begin{array}{c}\text { Con- } \\
\text { version } \\
(\%)\end{array}$ & $\begin{array}{l}\text { M. mole } \\
\text { fraction } \\
\text { in } \\
\text { polymer }\end{array}$ \\
\hline 14 & 0.911 & 1.5 & 2. 38 & 0.216 \\
\hline 15 & 0.784 & 1. 25 & 3. 11 & 0.0762 \\
\hline 16 & 0.685 & 1.0 & 1. 71 & 0.0483 \\
\hline 17 & 0.609 & 1.25 & 5.67 & 0.0401 \\
\hline 18 & 0.401 & 1. 25 & 8. 66 & 0.0322 \\
\hline 19 & 0.921 & 5.0 & 2.85 & 0.219 \\
\hline 20 & 0.961 & 5.0 & 1.03 & 0.376 \\
\hline 21 & 0.977 & 24.0 & 4. 15 & 0.600 \\
\hline
\end{tabular}

Table 4. Copolymerization of vinyl acetate $\left(M_{1}\right)$ and ethyl vinyl carbonate $\left(M_{2}\right)$.

$\left[\mathrm{M}_{1}\right]+\left[\mathrm{M}_{2}\right]=2 \mathrm{~mol} / \mathrm{l}$ in benzene, $[\mathrm{AIBN}]=0.01 \mathrm{~mol} / l, 60^{\circ} \mathrm{C}$

\begin{tabular}{l|l|l|c|c}
\hline \hline Expt. & $\begin{array}{l}\mathrm{M}_{2} \text { mole } \\
\text { fraction }\end{array}$ & $\begin{array}{c}\text { Poly. } \\
\text { merization } \\
\text { time } \\
\text { No. }\end{array}$ & $\begin{array}{c}\text { Con- } \\
\text { in } \\
\text { morsion } \\
(\%)\end{array}$ & $\begin{array}{l}\mathrm{M}_{2} \text { mole } \\
\text { fraction } \\
\text { in }\end{array}$ \\
\hline 22 & 0.901 & 3.10 & 7.45 & 0.894 \\
23 & 0.701 & 3.17 & 0.81 & - \\
24 & 0.601 & 3.17 & 9.66 & 0.586 \\
25 & 0.501 & 3.10 & 9.76 & 0.487 \\
26 & 0.401 & 3.17 & 10.53 & 0.395 \\
27 & 0.301 & 3.17 & 11.13 & 0.309 \\
28 & 0.201 & 2.00 & 7.25 & 0.213 \\
29 & 0.101 & 3.10 & 11.89 & 0.117 \\
\hline
\end{tabular}

Table 5. Monomer reactivity ratios.

\begin{tabular}{c|c|c|c}
\hline \hline $\mathrm{M}_{1}$ & $\mathrm{M}_{2}$ & $r_{1}$ & $r_{2}$ \\
\hline$p$-CISt & DVC & 27.5 & 0.036 \\
VAc & DVC & $0.77 \pm 0.05$ & $1.33 \pm 0.08$ \\
$p$-CISt & EVC & $39.8 \pm 0.7$ & $0.025 \pm 0.017$ \\
VAc & EVC & $0.87 \pm 0.04$ & $0.79 \pm 0.07$ \\
\hline
\end{tabular}

また Table 5 の $r_{1} ， r_{2}$ の值より得られる共重台組成曲 線と堅測值のプロットを Fig. 1〜4 に示した。Fig. 1 〜 にには阔時に, 共重合速度をモノマー組成についてブ ロットしたるのす示した。

$3.2 Q, e$ 值 


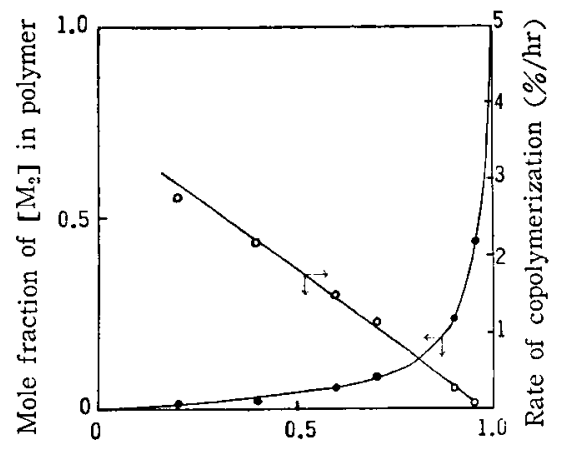

Mole fraction of $\left[\mathrm{M}_{2}\right]$ in monomer

- : The curve was calculated for $r_{1}=27.5$, $r_{2}=0.036$.

$O$ : Rate of copolymerization

$\left[\mathrm{M}_{1}\right]+\left[\mathrm{M}_{2}\right]=2 \mathrm{~mol} / l, \quad[\mathrm{AIBN}]=0.01 \mathrm{~mol}$ $/ l$ in benzene at $60^{\circ} \mathrm{C}$

Fig. 1. Copolymer composition curve and rate of copolymerization for the system: divinyl carbonate $\left(\mathrm{M}_{2}\right)$-p-chlorostyrene $\left(\mathrm{M}_{1}\right)$.

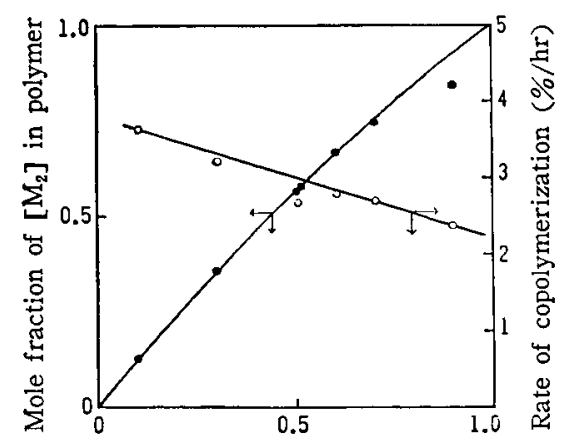

Mole fraction of $\left[\mathrm{M}_{2}\right]$ in monomer

- : The curve was calculated for $r_{1}=0.77$, $r_{2}=1.33$.

0 : Rate of copolymerization

$\left[\mathrm{M}_{1}\right]+\left[\mathrm{M}_{2}\right]=2 \mathrm{~mol} / \mathrm{l}, \quad[\mathrm{AIBN}]=0.01 \mathrm{~mol}$ $/ l$ in benzene at $60^{\circ} \mathrm{C}$

Fig. 2. Copolymer composition curve and rate of copolymerization for the system: divinyl carbonate $\left(M_{2}\right)$-vinyl acetate $\left(M_{1}\right)$.

Table 6. Q-e, values.

\begin{tabular}{c|c|c|c}
\hline \hline $\mathrm{M}_{1}$ & $\mathrm{M}_{2}$ & $Q_{2}$ & $e_{2}$ \\
\hline$p$-CISt & DVC & 0.036 & -0.23 \\
VAc & DVC & 0.034 & -0.22 \\
$p$-C1St & EVC & 0.025 & -0.26 \\
VAc & EVC & 0.026 & +0.39 \\
\hline
\end{tabular}

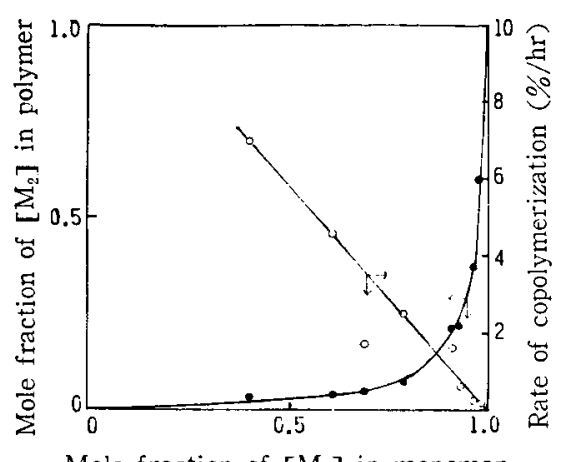

Mole fraction of $\left[\mathrm{M}_{2}\right]$ in monomer

-: The curve was calculated for $r_{1}=39.8$, $r_{2}=0.025$.

$O$ : Rate of copolymerization

Bulk copolymerization, [AIBN] $=0.5 \mathrm{~mol}$ $\%$ /monomer at $60^{\circ} \mathrm{C}$

Fig. 3. Copolymer composition curve and rate of copolymerization for the system: ethyl vinyl carbonate $\left(M_{2}\right)$-p -chlorostyrene $\left(M_{1}\right)$.

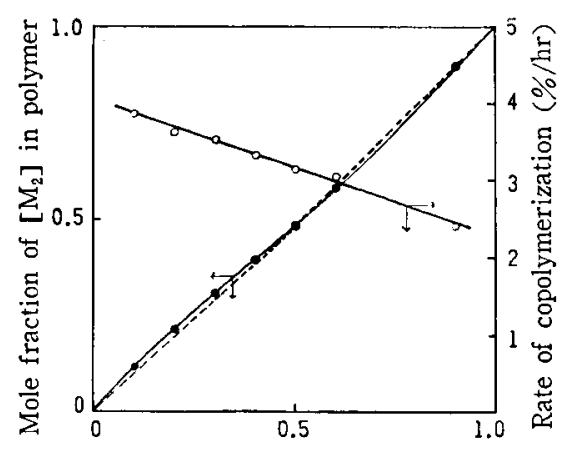

Mole fration of $\left[\mathrm{M}_{2}\right]$ in monomer

- : Solid line was calculated for $r_{1}=0.87$, $r_{2}=0.79$.

Dashed line was calculated for $r_{1}=1.03$, $r_{2}=0.97$.

$O$ : Rate of copolymerization

$\left[\mathrm{M}_{1}\right]+\left[\mathrm{M}_{2}\right]=2 \mathrm{~mol} / l, \quad[\mathrm{AIBN}]=0.01 \mathrm{~mol}$ $/ l$ in benzene at $60^{\circ} \mathrm{C}$

Fig. 4. Copolymer composition curve and rate of copolymerization for the system: ethyl vinyl carbonate $\left(M_{2}\right)$-vinyl acetate $\left(M_{1}\right)$.

$Q, e$ の值を Table 5 の $r_{1}, r_{2}$ 值より求めた。 $p$-ク口 ルスチレンの $Q=1.03, e=-0.33$ ，打よび酶酸ビニル の $Q=0.026, e=-0.22$ の值を用いた ${ }^{2 !}$ 。その結果を Table 6 に示した。楸酸エチルビニルー䣫酸ビニルの系 から得られた炭酸エチルビニルの $e$ の侐が他のそれと大

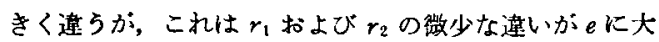


きく効いているためであろら。たとえば，岸酸エチルビ $=ル の Q, e$ 值を炭酸エチルビニルーpークロルスチレン の系から得られた $Q=0.025, e=-0.26$ とすると,酢 酸ビニルとの系では $r_{1}=1.03, r_{2}=0.97$ となり、この 但から求め大共重合組成曲線もまた実測値と大きくはず れない(Fig. 4 の点線)。

3.3 共重合体の IR スペクトル

Fig. 5〜7に見られるょうにすべての共重合体の IR スペクトルは, 各単独重合体のIRスペクトルを重ね合 わせたスペクトルを示した。すなわち共重合体の構造と

Table 7. Structure of DVC-p-ClSt copolymers.

\begin{tabular}{l|c|c|c|c}
\hline \hline $\begin{array}{l}\text { Expt, } \\
\text { No. }\end{array}$ & $\begin{array}{l}p \text {-ClSt } \\
(\mathrm{mol} \%)\end{array}$ & $\begin{array}{l}\text { Pendant } \\
\text { vinyl } \\
\text { carbonate } \\
(\mathrm{mol} \%)\end{array}$ & $\begin{array}{l}\text { 6-membered } \\
\text { ring } \\
\text { carbonate } \\
(\mathrm{mol} \%)\end{array}$ & $\begin{array}{l}\text { 5-membered } \\
\text { ring } \\
\text { carbonate } \\
(\mathrm{mol} \%)\end{array}$ \\
\hline 1 & 72 & 15 & 8.0 & 5.1 \\
2 & 87 & 6.8 & 4.9 & 1.5 \\
\hline
\end{tabular}

して，単独重合に打けるように"1)，(1)式（2）式に示 した各满造単位の存在が予想される。

敬酸シビニルー $\boldsymbol{D}$ ークロルスチレン<smiles>CCC(C)c1ccc(Cl)cc1</smiles><smiles>C=CC(=O)OC(C)CC</smiles>

[I]

[II] $\nu_{\mathrm{C}=\mathrm{c}} 1652 \mathrm{~cm}^{-1}$ $\nu_{\mathrm{c}}=0.1760 \mathrm{~cm}^{-1}$<smiles>CCC1CC(C)OC(=O)O1</smiles>

[III] $\nu_{\mathrm{c}=0}{ }_{1760 \mathrm{~cm}^{-1}}$<smiles>CCC1OC(=O)OC1CC</smiles>

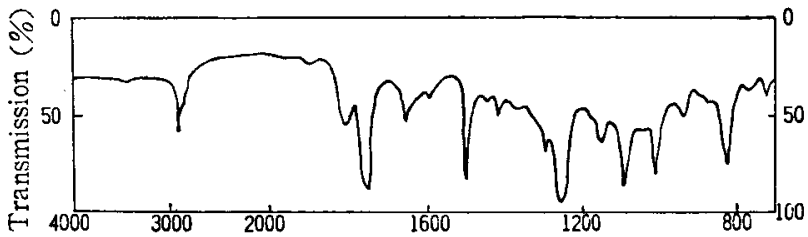

Wave number $\left(\mathrm{cm}^{-1}\right)$

Fig. 5. IR spectrum of copolymer of divinyl carbonate with $p$-chlorostyrene, expt. No. 1.

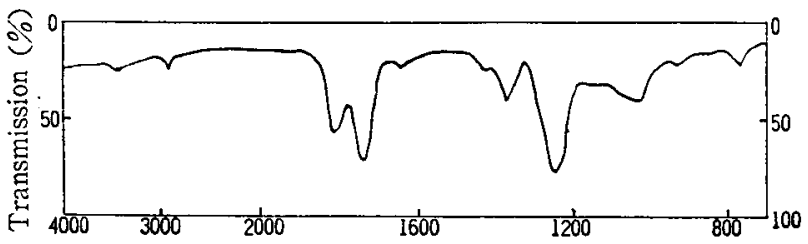

Wave number $\left(\mathrm{cm}^{-1}\right)$

Fig. 6. IR spectrum of copolymer of divinyl carbonate with vinyl acetate, expt. No. 11.

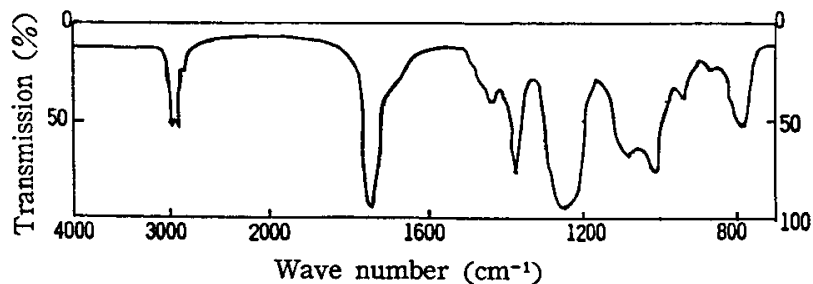

Fig. 7. IR spectrum of copolymer of ethyl vinyl carbonte with vinyl acetate, exp. Not 27 .

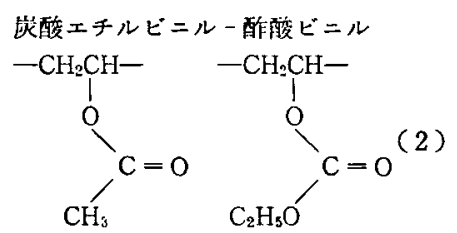

Fig. 5 に見られるよ5に，（I）式にお いて,[II]，[III]扰よび〔IV]の各權造単 位の特微的な吸収, $1815 \mathrm{~cm}^{-1}, 1760 \mathrm{~cm}^{-1}$ 扣よび $1652 \mathrm{~cm}^{-1}$ のある领域に[I]に基く 吸収がないので，削報で報告した方法によ

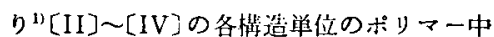
のモル\%を推定できる。その結果を Table 7 に示した。

沾酸ジビニルー酶酸ビニルの系（Fig， 6) では,醀酸ビニルのカルボニルの吸収が

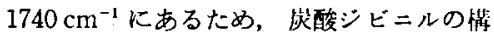
造解析は行なえない。しかし，阔一温度で

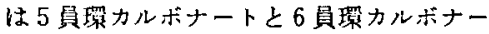
トの生成此はだいたい一定と考えられるの で(たとえば㓩報”の結果を参照)ポリマ

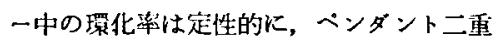
結合の吸収 $1652 \mathrm{~cm}^{-1}$ の吸光度と 5 員環力 ルボナートの吸収, $1815 \mathrm{~cm}^{-1}$ の吸光度を 比較して知ることができる。の吸光度比 を炭酸ジビニルーかークロルスチレン，炭酸 ジビニルー酢酸ビニルおよび孷酸シビニル 単独重合体について比较したのが T able 8 である。相手モノマーにより環化率に変化 
Table 8. Structural variations of divinyl car bonate units in copolymers.

Monomer concentration $2 \mathrm{~mol} / \mathrm{l}$ in benzene. $60^{\circ} \mathrm{C}$

\begin{tabular}{l|r|c|c|c|c|c|}
\hline \hline \multirow{2}{*}{$\begin{array}{l}\text { Expt. } \\
\text { No. }\end{array}$} & \multicolumn{2}{|c|}{$\begin{array}{c}\text { DVC.VAC } \\
\text { copolymer }\end{array}$} & \multicolumn{2}{c|}{$\begin{array}{l}\text { DVC-p-CISt } \\
\text { copolymer }\end{array}$} & $\begin{array}{l}\text { DVC } \\
\text { homo- } \\
\text { polymer }\end{array}$ \\
\cline { 2 - 7 } & 7 & 10 & 12 & 1 & 2 & \\
\hline$D_{1815}$ & 10 & 10 & 3.8 & 1.4 & 0.45 & 5.4 \\
\hline
\end{tabular}

のあることがかかる。

\section{1. 考案}

環化重合をするモノマーの共重合については, その重 合様式が多様であるため，共重合反応は複雑となり，正 確な共重合組成式を求めることはかなり困難である。環

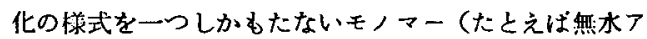
クリル酸のように 6 員環が唯一の環構造と考えられるも フマー) では, Smets ら゙および Gibbs ら"によって その共重合組成式が求められている。

嵌酸シビニルでは，ボリマーの IR スペクトルから, ポリマー中にベンダントビニルカルボナート，6貣環お よび 5 員㻴カルボナートの3 種の满造単位が涊められて いる。ここで, 共重合体成長反応の素反店のうち, 橋か け反応を無視し，また， 5 員謤おおび6員㻴カルボナー トの生成比を一定として，その合計を環满造としてまと めると, 結局, Smets らの取扱いと同等となる31。ここ で前考の仮定は，重合染を低くおさえているので妥当で あろ5。また後者の仮定も，同一温度では 5 員理と 6 員 檌の生成此が重合条件によらずほぼ一定である゙ので罗 当である。すなわち，動力学的連銷長が十分に大である こと怙よび, 各ラジルの定常状態が成立すれば, 共重 合組成式として(3)式を導くことができる゙๋。

$$
\begin{aligned}
& \frac{d\left[\mathrm{M}_{1}\right]}{d\left[\mathrm{M}_{2}\right]} \\
= & \frac{\left[\mathrm{M}_{1}\right]}{\left[\mathrm{M}_{2}\right]} \times\left\{\frac{r_{1}\left[\mathrm{M}_{1}\right]+\left[\mathrm{M}_{2}\right]+K_{\mathrm{c}}\left(\frac{r_{1}\left[\mathrm{M}_{1}\right]+\left[\mathrm{M}_{2}\right]}{r_{\mathrm{c}}\left[\mathrm{M}_{2}\right]+\left[\mathrm{M}_{1}\right]}\right)}{r_{2}\left[\mathrm{M}_{2}\right]+\left[\mathrm{M}_{1}\right]+K_{1}}\right\}
\end{aligned}
$$

ここで $r_{\mathrm{e}}=k_{\mathrm{c} 2} / k_{\mathrm{c} 1}$ (罯ラシカルに対するモノマー $\mathrm{M}_{\mathrm{l}}$, $\mathrm{M}_{2}$ の反応性化) $K_{\mathrm{c}}=k_{\mathrm{c}} / k_{21}\left(\mathrm{M}_{2}\right.$ ラジカルに $\mathrm{M}_{1}$ モ マ 一が付加する速度に対する， $\mathrm{M}_{2}$ ラシカルのの環化する速 度)である。

(3) 式は次の三つの条件のいずれか成立すれば, Mayo-Lewis の共重合組成式と同等である。

1) $K_{c} \fallingdotseq \infty\left(1 / K_{c} \fallingdotseq 0\right)$ すなわち，汪とんど塄化す る場合

2） $K_{c} \fallingdotseq 0$ ，汪とんど環化しない場合

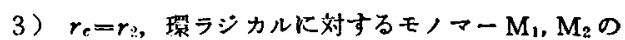
反応性此が， $\mathrm{M}_{n}$ ラシカカルに対するそれと变わらないと き,

族酸ジビニルでは，1）も2）あ成泣しない，また，共 手合体中では正確な愣化率を求めることは图難である。 そこで 2 つの条件の成立を仮定して, Mayo-Lewis の共 画公組成式を用いて，モノマ一反応性 $r_{1} ， r_{2}$ を求めた。 Table 6 k見られるように, このようにして求めた $r_{\text {s }}$, $r_{2}$ より得られる $Q$ および $e$ 值が相手モノマーが変わっ

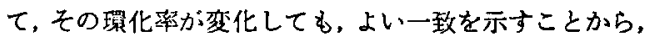
上の仮定の妥当性を示していると思われる。

Table 5，6，Fig. 2，4に見られるょ5に，炭酸ジビ ニル，岸酸エチルビニルとも䣫酸ビニルに非常によく似 た重合反応性を示すことがわかった。これは-OCOOR と -OCOR との間には，ビニル基に与える効果については とんど差のないことを示している。

岑酸ジ゙ニルと炭酸エチルビニルとの間のQの值のわ ずかな違いは，その原因として次の二つが考えられる。

i ）環化反応による効果

ii）置換基効果

i）の環化反応による効果は, Table 8 に見られるよ ろに，その環化率が相手モノマーによりかなり影響され ていると思われるにもかかわらず，相手モノマーの変化 によりQの値に差のないことから考えにくい。ii）の置 換基效果についても，直換基の違いがビニル基よりかな り潅れているために大きくはないであるらが、ビニル基 とエチル基の間の違いが出て来ていると思われる。すな わち炭酸ジビニルと炭酸ニチルビニルの間に大きな善が ないことから，同一分子中に 2 㑑のビニル㔨があるため の特別な效果はないことが推定される。

Table: 8 に見られるよらに，岑酸ジヒニルの理化反応 におよほすす相手モノマーの影罊はかなり著しいと思われ る。すなわら、ベンダントビニルカルボナートを基準とし た 5 員㯰》ルボナートの生成割台は，前述のよ5に定性 的に㯰化率を示すと考えられるが，二の值は，炎酸ジビ

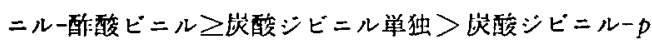
ークロルスチレンの颇であることがわかった。これは名 モノマーの $\mathrm{M}_{2}$ ラジカル来端 $\left(\sim \mathrm{CH}_{2} \mathrm{CH}\right.$ ) への反応性 $\mathrm{O} \mathrm{COOCH}=\mathrm{CH}_{2}$ から推定できる。すなわち Table 5 の $\boldsymbol{r}_{2}$ の值 から， $\mathrm{M}_{2}$ ラシカル末端への各モ,マーの反庍性は，炭酸シビ ニルを基準として，pークロルスチレン 28 , 炭酸ジビ二 ル=1, 酢酸ビニルミ0.75 である。 $\mathrm{M}_{2}$ ラシカル末端が 眇化する確率は, 酢酸ビニルとの共重合で最も大きく, pークロルスチレンとの共重合で小さいと考えられるこ とと矛盾しない。

付 記：本研究の一部は第 12 回高分子研究 発表会 
（神戸，1966年）において登表した。

\section{文献}

1) S. Murahashi, S. Nozakura, S. Fuji, K. Kikukawa: Bull. Chem. Soc. Japan, 38, 1905 (1965)
2) G.E. Ham: "Copolymerization", 862 (1964) Interscience Publishers

3) G. Smets, N. Deval, P. Hous: J. Polymer Sci., A 2, 4835 (1964)

4) W.E. Gibbs, R.J. McHenry: J. Polymer Sci., A 2, 5277 (1964)

\section{Copolymerization of Divinyl Carbonate}

By Kiyoshi Kikukawa*, Shun'ichi Nozakura* and Shunsuke Murahashi*

Copolymerization parameters of divinyl carbonate (DVC)were determined by the copolymerization with $p$-chlorostyrene ( $p$-CISt) and vinyl acetate (VAc), and compared with those of ethyl vinyl carbonate (EVC). $Q$ and $e$ values are: $Q=0.035, e=-0.23$ for DVC and $Q$ $=0.025, e=-0.26$ for EVC. These values suggest that copolymerization reactivities of DVC and EVC are alike each other and are close to that of VAC $(Q=0.026, e=-0.22)$. Since divinyl carbonate undergoes a cyclization polymerization to considerable extents, the data also suggest that there is no extraordinary effect of the cyclization reaction on copolymerization parameters. Extent of cyclization of DVC was found to be lower in the DVC-p-CISt copolymer than in the DVC-VAc copolymer.

* Department of Polymer Science, Faculty of Science, Osaka University (Toyonaka, Osaka) 


\section{Chapter II}

Effect of 1,2-Glycol Structure and Stereoregularity of Poly(vinyl alcohol) on Poly(vinyl alcohol)-Iodine Reaction

\section{Synopsis}

The poly(vinyl alcohol)-iodine blue color reaction in dilute aqueous solution has been investigated at $6-8^{\circ} \mathrm{C}$ and extinctions at the absorption maximum have been measured as a function of the 1,2-glycol content and stereoregularity of poly(vinyl alcohol) (PVA). The increase of the 1,2-glycol content and-of isotacticity remarkably decreased the color intensity. Particularly, when the 1,2-glycol content was larger than 5 mol\% or isotacticity Was more than $70 \%$, the reaction mixture was almost colorless. Wave length of the absorption maximum of the reaction mixture was not affected by the 1,2-glycol content $(608 \mathrm{~m} \mu)$, whereas the maximum was shifted to shorter wave length by the increase of isotacticity. It is suggested that the 1,2-glycol structure simply decreased the content of the PVA-iodine complex. Sequence length of $1,3-g l y c o l$ units required for the color reaction of atactic PVA was estimated to be about 120. Isotactic structure, 
on the other hand, may not only disturb the formation of the complexes, but may also affect its structure.

\section{Introduction}

Various physical properties of poly(vinyl alcohol)(PVA) may be affected by molecular weight, 1,2-glycol structure, residual acetate group, branching, stereoregularity etc. PVA samples with different stereoregularities have been prepared in order to study qualitatively the effect of stereoregularity on crystallinity, solubility to water and so on ${ }^{1)}$. It has also been informed that the increase of the 1,2-glycol content lowers the melting point of PVA and deteriorates crystallinity ${ }^{2}$.

The blue color reaction of PVA with iodine proceeds in a similar manner to the amylose-iodine reaction. The intensity of the blue color was known to vary delicately with various kinds of PVA specimens and the fact has been interpreted to be due to ninor changes in the molecular structure of PVA. Among many structural variations, the effect of molecular weight has been studied quantitatively ${ }^{3)}$.

The present study was undertaken to eluciciate the role of the 1,2-glycol structure and stereoregularity on the PVA-iodine reaction. During the course of our study Shibatani et al. reported 
the effect of these variabies on the color intensity of the

PVA-iodine reaction ${ }^{4}$ ). We have obtained further informations about the position of the absorption maximum in addition to the intensity. The nature of the complex will be discussed on tnis basis.

\section{Experimental}

\section{Preparation of Polymers}

PVA samples with different 1,2-glycol contents were prepared by hydrolyzing copolymers of vinyl acetate and divinyl carbonate. Polymerization was carried out in methanol at $1^{\circ} \mathrm{C}$ using a monomer concentration of $2 \mathrm{~mol} / 1$ and triisobutylboron as a catalyst. The results of copolymerization are given in Table $I$ and Figure $I$, and the degree of polymerization and the 1,2-glycol content of resulting PVA are given in Table II. Monomer reactivity ratios are found to be $r_{V A C}=0.41$ and $r_{D V C}=1.55$. Former values in the presence of azobisisobutyronitrile as catalyst are 0.77 and 1.33 , respectively ${ }^{5)}$.

PVA samples with 1,2,3-triol structure were piepared by hydrolyzing a copolymer of vinyl acetate and vinylene carbonate. Polymerization conditions are the same as in the vinyl acetatedivinyl carbonate copolymerization. The degree of polymerization 
and the 1,2,3-triol content of resulting PVA are given in Table III. PVA samples with different stereoregularity were prepared using various polymerization conditions and starting monomers. Polymerization conditions are summarized in Table IV. Stereoregularity and degree of polymerization are given in Tables $V$ and VI. Determination of $1,2-G l y c o l$ Content in PVA

1,2-Glycol content was determined by titrating the periodic acid consumption by PVA in accordance with the method of Harris et al.6) It was assumed that the $-\mathrm{CH}(\mathrm{OH})-\mathrm{CH}(\mathrm{OH})-\mathrm{CH}(\mathrm{OH})$ - structure, formed by the copolymerization of vinylene carbonate and vinyl acetate, may consume 2 moles of periodic acid, and thus the triol structure was regarded as one $1,2-g l y c o l$ structure. Dtermination of Tacticity

Triad tacticity was determined from NMR spectra of poly(vinyl acetate) derived from PVA samples using a JNM 4-100 spectrometer of Japan Electron Optics Laboratory Co. Ltd. 7) In some cases diad tacticity was calculated from the absorbance ratio, $\mathrm{D}_{916} / \mathrm{D}_{849}$, of IR spectra of PVA films according to the equation presented by Murahashi et al ${ }^{\text {) }}$. The PVA-Iodine Color Reaction

An aqueous PVA solution was mixed with a $\mathrm{KI}-\mathrm{I}_{2}$ solution at $6-8^{\circ} \mathrm{C}$ and kept at this temperature for $20 \mathrm{hrs}$ and the mixture was subjected to spectroscopic measurement at room temperature using a Hitach 1 spectrophotometer, LPS-3T. 


\section{Results}

Influence of the 1,2-Glycol structure on the PVA-Iodine Reaction

Table II and Figure 2 show the influence of 1,2-8lycol content on the PVA-iodine reaction. The 1,2-glycol structure extensively reduced the intensity of the blue color of the reaction mixture. Particularly, it is to be noted that the position of the absorption maximum was unaltered $(608 \mathrm{~m} \mu$ and that PVA in which 1,2-glycol content is more than 5mol\% was unable to develop the color. The absorption maximum shifted to $680 \mathrm{~m} \mu$ when boric acid was added.

Influence of Stereoregularity

Tables $V$ and VI show the coloring abilities of PVA samples with various stereoregularities. The difference in stereoregularity markedly affected the PVA-iodine reaction, and particularly the EVA samples with diad syndiotacticity less than $30 \%$ did not have any visible absorption at all. The coloring ability in this case mainly depends on the increase of syndiotacticity.

It is characteristic that the PVA samples with approximately $40 \%$ syndiotacticity had the absorption maximum at a shorter wave length than the PVA samples with higher syndiotacticity. The syndiotacticity higher than $44 \%$ almost unaltered the absorption maximum and the increase in syndiotacticity resulted in the increase in extinction. 
Table I. Copolymerization of vinyl acetate $\left(M_{1}\right)$ and divinyl carbonate $\left(\mathrm{M}_{2}\right)$.

$\left[\mathrm{M}_{1}\right]+\left[\mathrm{M}_{2}\right]=2 \mathrm{~mol} / \mathrm{l}$ in methanol, Catalyst; triisobutylboron $0.5 \mathrm{mmol}$, at $1^{\circ} \mathrm{C}$.

Exp. $\quad \mathrm{M}_{2}$ mole fraction Polymerization Conversion $M_{2}$ mole fraction No. in monomer a) time, $\mathrm{hr}$ \% in copolymer a)

$\begin{array}{lllll}3 & 0.194 & 3 & 15.1 & 0.337 \\ 4 & 0.291 & 2.7 & 6.4 & 0.506 \\ 5 & 0.390 & 2.7 & 11.9 & 0.551 \\ 6 & 0.490 & 2.5 & 16.0 & 0.630 \\ 7 & 0.590 & 2.3 & 19.7 & 0.720 \\ 8 & 0.691 & 2.2 & 18.6 & 0.786 \\ 9 & 0.793 & 2 & 19.0 & 0.866 \\ 10 & 0.896 & 2 & 18.7 & 0.908\end{array}$

a) One mole of divinyl carbonate was regarded as two equivalent 
Table II. The effect of the 1,2-giycol structure on the PVA-iodine reaction

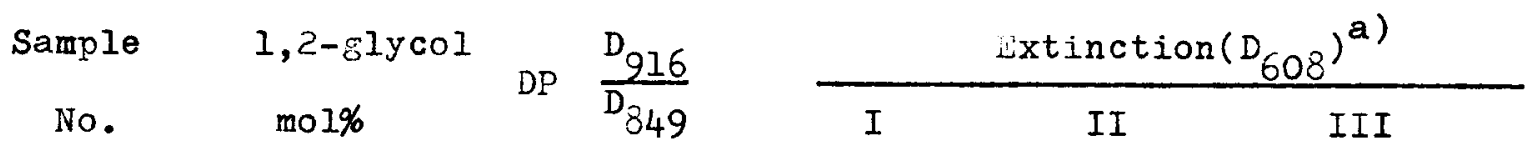

\begin{tabular}{ccccccc}
1 & 1.41 & 623 & 0.35 & 3 & 1.88 & - \\
2 & 1.87 & 631 & 0.40 & 2.8 & 1.41 & - \\
3 & 2.73 & 518 & 0.34 & 1.08 & 0.50 & - \\
4 & 3.17 & - & - & - & - & 0.83 \\
5 & 4.09 & 342 & 0.29 & 0.26 & - & 0.47 \\
6 & 4.69 & 335 & 0.29 & 0.11 & - & 0.19 \\
7 & 5.09 & 310 & 0.26 & 0.048 & - & 0.14 \\
8 & 5.67 & 332 & 0.29 & 0.026 & - & 0.037 \\
9 & 5.17 & - & 0.27 & 0.013 & - & 0.017 \\
10 & 6.66 & 290 & - & 0.009 & - & - \\
Commercial & 2.10 & 500 & 0.36 & 2.48 & 1.10 & \\
\hline
\end{tabular}

a) Reaction condition:

$I:(\mathrm{PVA})=25 \mathrm{mmol} / 1,\left[\mathrm{I}_{2}\right]=1.25 \mathrm{mmol} / 1,[\mathrm{KI}]=2.5 \mathrm{mmol} / 1,20 \mathrm{hrs}, 6-3^{\circ} \mathrm{C}$

II: $(\mathrm{PVA})=14.5 \mathrm{mmol} / 1,\left[\mathrm{I}_{2}\right]=0.87 \mathrm{mmol} / \mathrm{l},[\mathrm{KI}]=1.75 \mathrm{mmol} / 1,24 \mathrm{hrs}, 6-8^{\circ} \mathrm{C}$

III: Two $\mathrm{ml}$ of an $0.5 \mathrm{~mol} / \mathrm{l}$ aqueous boric acid solution was added to $7 \mathrm{ml}$ of the reaction mixture of $I$ and allowed to react for 24 hrs at $6-8^{\circ} \mathrm{C}$ 
Table III. The effect of the 1,2,3-triol structure on the PVAiodine reaction

\begin{tabular}{ccccc}
$\begin{array}{c}\text { Sample } \\
\text { No. }\end{array}$ & $\begin{array}{c}1,2,3-\text { triol } \\
\text { mol\% }\end{array}$ & DP & $\frac{D_{916}}{D_{849}}$ & $\begin{array}{c}\text { Extinction } \\
\left(D_{607}\right)\end{array}$ \\
11 & 2.13 & 617 & 0.37 & 1.60 \\
12 & 10.9 & 392 & 0.28 & 0.22 \\
13 & 11.6 & 604 & 0.29 & 0.09 \\
14 & 18.7 & 408 & 0.23 & 0.03 \\
\hline
\end{tabular}

a) Reaction concition:

$[\mathrm{PVA}]=30 \mathrm{mmol} / 1,\left[\mathrm{I}_{2}\right]=1.25 \mathrm{mmol} / \mathrm{l},[\mathrm{KI}]=5 \mathrm{mmol} / 1,20 \mathrm{hrs}, 6-8^{\circ} \mathrm{C}$ 
Table IV. Preparation of PVA samples with different stereoregularities

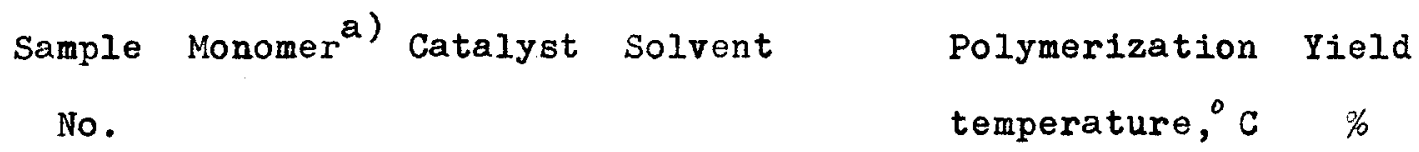

\begin{tabular}{|c|c|c|c|c|c|c|}
\hline 21 & $\left.\operatorname{Vosi}{ }^{b}\right)$ & $\operatorname{EtAICl}{ }_{2}{ }^{c)}$ & \multicolumn{2}{|c|}{ Toluene } & -95 & - \\
\hline 22 & $" 1$ & $"$ & \multicolumn{2}{|c|}{ Toluene- $\mathrm{CH}_{2} \mathrm{Cl}_{2}$} & -78 & 86 \\
\hline 23 & $"$ & $"$ & " & $(6: 4)$ & $"$ & 58 \\
\hline 24 & $"$ & " & $"$ & $(4: 6)$ & $"$ & 53 \\
\hline 25 & 11 & $"$ & $"$ & $(5: 5)$ & $n$ & 100 \\
\hline 26 & $"$ & $"$ & $" 1$ & $(3: 7)$ & $"$ & 59 \\
\hline 27 & $"$ & $" 1$ & \multicolumn{2}{|c|}{$\mathrm{CH}_{2} \mathrm{Cl}_{2}$} & $"$ & 100 \\
\hline 28 & $"$ & " & \multicolumn{2}{|l|}{$"$} & -95 & - \\
\hline 29 & $"$ & $"$ & \multicolumn{2}{|l|}{$" 1$} & -78 & - \\
\hline 30 & $"$ & "I & \multicolumn{2}{|l|}{$"$} & -60 & - \\
\hline
\end{tabular}

4.1 VAC AIBN-UV ${ }^{\text {d) }}$ Methanol $30-31 \quad 81.5$

$\begin{array}{llllcl}42 " & " & \text { Hexane } & 11 & 87.7 \\ 43 & \text { " } & \text { Methanol } & 6-8 & 25.8\end{array}$

a) Monomer concentration was 20 vol\%.

b) Vinyl trimethyl $\widehat{\mathbf{s i l y}}$ ether.

c) Catalyst concentration was $0.0125 \mathrm{~mol} / 1$.

d) Photosensitizel polymerization. 
Table V. The effect of stereoregularity on the PVA-iodine reaction

\begin{tabular}{|c|c|c|c|c|c|c|}
\hline \multirow{3}{*}{$\begin{array}{c}\text { Sample } \\
\text { No. }\end{array}$} & \multirow{3}{*}{$\mathrm{DP}$} & \multirow{3}{*}{$\begin{array}{l}\text { Syndiotacticity } \\
\text { diad, } \%^{c)}\end{array}$} & \multicolumn{4}{|c|}{ Extinction ${ }^{a)}$} \\
\hline & & & \multicolumn{2}{|c|}{ I } & \multicolumn{2}{|c|}{ II } \\
\hline & & & $\lambda \overline{\max }$ & $\mathrm{D}_{\max }$ & $\lambda \max$ & $\overline{D_{\max }}$ \\
\hline \multirow[t]{2}{*}{21} & 2322 & 12 & none & - & $400-600$ & $0.33-0.34$ \\
\hline & & & & \multicolumn{3}{|c|}{ broad peak } \\
\hline 22 & 1520 & 20 & none & - & $"$ & $0.1-0.2$ \\
\hline 23 & 1485 & 29 & none & - & - & - \\
\hline 24 & 678 & 39 & 562 & 0.27 & - & - \\
\hline 25 & 1171 & 40 & 571 & 0.27 & 650 & 0.61 \\
\hline 26 & 1010 & 44 & 620 & 0.31 & - & - \\
\hline 27 & 858 & 55 & $(616)^{b)}$ & $(1.06)^{b)}$ & 654 & 2.21 \\
\hline
\end{tabular}

a) Reaction conditions:

I: $[\mathrm{PVA}]=14.0 \mathrm{mmol} / 1,\left[\mathrm{I}_{2}\right]=2.00 \mathrm{mmol} / 1,[\mathrm{KI}]=3.00 \mathrm{mmol} / 1,6-8^{\circ} \mathrm{C}, 20 \mathrm{hrs}$.

II: $[\mathrm{PVA}]=7.0 \mathrm{mmol} / 1,\left[\mathrm{I}_{2}\right]=0.33 \mathrm{mmol} / 1,[\mathrm{KI}]=0.5 \mathrm{mmol} / 1,\left[\mathrm{H}_{3} \mathrm{BO}_{3}\right]=100 \mathrm{mmol} / 1$ $6-8^{\circ} \mathrm{C}$, $20 \mathrm{hrs}$.

b) $\left[I_{2}\right]=0.667 \mathrm{mmol} / 1,[\mathrm{KI}]=1.00 \mathrm{mmol} / 1$, other conditions are the same as I.

c) Diad tacticity was calculated from the absorbance ratio, $D_{916} / D_{849}$, of IR spectra of PVA filme?). 
Table VI. The effect of stereoregularity on the PVA-iodine reaction

\begin{tabular}{|c|c|c|c|c|c|c|c|c|}
\hline \multirow{3}{*}{$\begin{array}{c}\text { Sample } \\
\text { No. }\end{array}$} & \multirow{3}{*}{ DP } & \multicolumn{5}{|c|}{ Stereoregularity $\%$} & \multicolumn{2}{|c|}{ Extinction } \\
\hline & & \multicolumn{2}{|c|}{$\operatorname{diad~}^{2)}$} & \multicolumn{3}{|c|}{ triad } & \multirow{2}{*}{$\lambda_{\max }$} & \multirow{2}{*}{$D_{\max }$} \\
\hline & & $i$ & 6 & $\mathrm{I}$ & $\mathrm{H}$ & $\mathbf{S}$ & & \\
\hline 28 & 2680 & 55 & 45 & 36 & 39 & 25 & 616 & 0.57 \\
\hline 29 & 180 & 49 & 51 & 26 & 46 & 28 & 620 & 1.07 \\
\hline 30 & 490 & 48 & 52 & 25 & 47 & 28 & 624 & 1.03 \\
\hline 41 & 1995 & 53 & 47 & 28 & 49 & 23 & 617 & 0.71 \\
\hline 42 & 2080 & 55 & 45 & 31 & 48 & 21 & 618 & 0.69 \\
\hline 43 & 3127 & 53 & 47 & 29 & 48 & 23 & 620 & 0.81 \\
\hline
\end{tabular}

a) Diad tacticity was calculated from the triad tacticity.

b) Reaction condition:

$[\mathrm{PVA}]=6.25 \mathrm{mmol} / 1,\left[\mathrm{I}_{2}\right]=5.5 \mathrm{mmol} / 1,[\mathrm{KI}]=16.7 \mathrm{mmol} / 1,6-8^{\circ} \mathrm{C}, 20 \mathrm{hrs}$. 


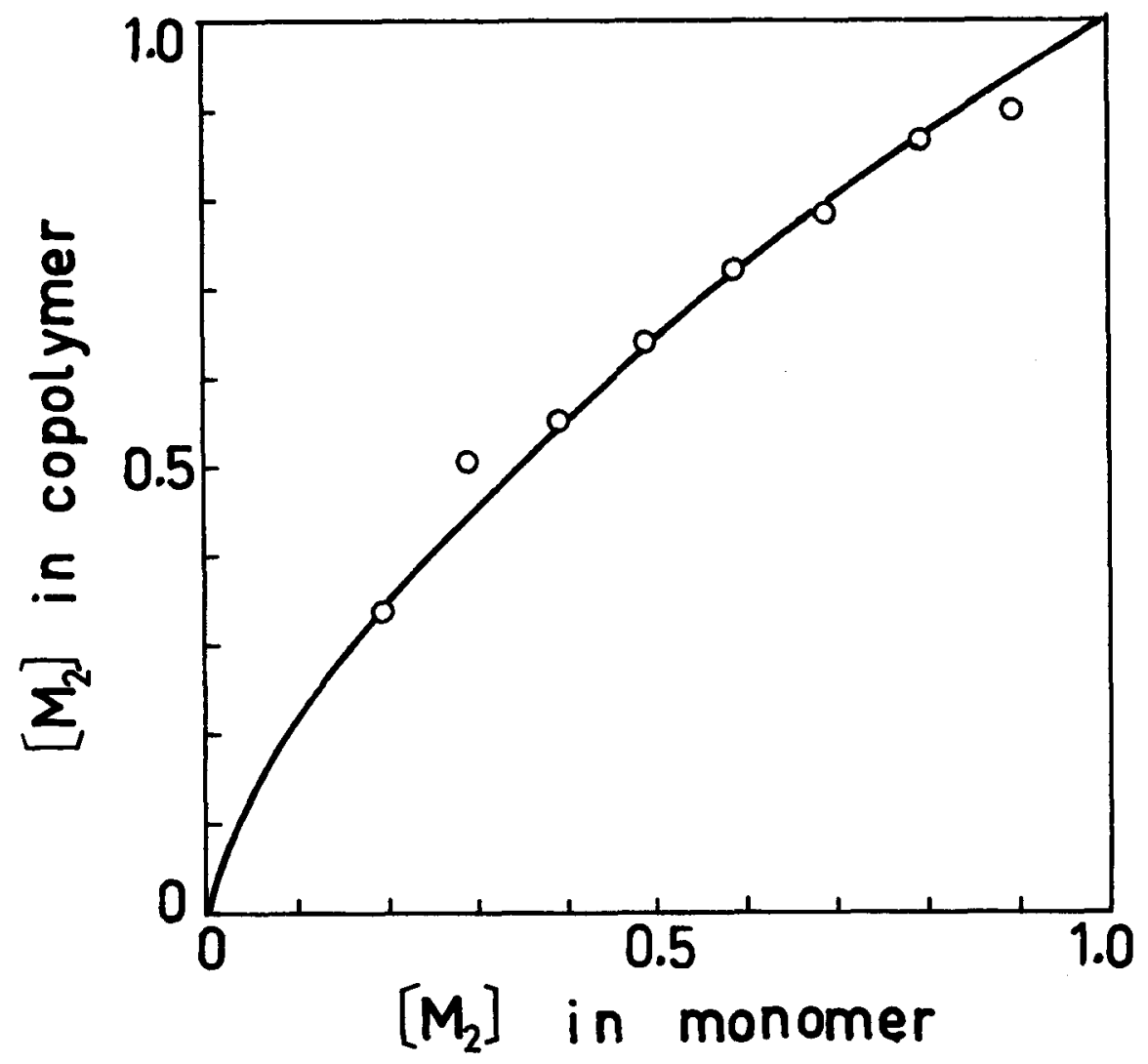

Figure 1. Copolymer composition curve for vinyl acetate $\left(M_{1}\right)$ and divinyl carbonate $\left(M_{2}\right)$

: $\left[M_{1}\right]+\left[M_{2}\right]=2 \mathrm{~mol} / 1$ in methanol at $1 \cdot \mathrm{C}$; catalyst, $(\mathrm{i}-\mathrm{Bu})^{3} \quad 0.33 \mathrm{~mol} \%$ of monomer; the curve is calculated for $r_{1}=0.41, r_{2}=1.55$ 


\section{Discussion}

Effect of the 1,2-Glycol Structure on the PVA-Iodine Reaction

The increase of $1,2-g l y c o l$ content, as shown in Figure 2, strongly influences the PVA-iodine reaction. Particularly when the 1,2-8lycol contents are larger than 5 mol\%, the reaction mixtures are colorless. The PVA samples are almost identical to one another with respect to stereoregularity and the degree of polymerization. Therefore, the decrease of the intensity of visible absorption (coloring ability) solely depends on the increase of the 1,2-8lycol content. Further, the fact that absorption maxima are unchanged independent of the 1,2-5lycol content suggests that ${ }_{\wedge}$ structures of the PVA-iodine complexes are identical to one another.

Table II shows that the IR absorbance ratios, $\mathrm{D}_{916} / \mathrm{D}_{849}$, decrease as the 1,2-glycol contents decrease. The values of $D_{916} / D_{849}$, however, may not reflect the stereoregularity of PVA when PVA has a large 1,2-8lycol content as informed earlier 5 ). The polymerization conditions suggest these PVA samples to be atactic.

We have previously reported that the 1,2-glycol structure is one of important factors which interfere with the crystallization of PVA. The influence of the 1,2-glycol structure in the present report differs from that on the crystallization. Figrue 3 shows that the melting point of PVA inversely corresponds to the $1,2-81 y c o l$ content when the contents are less than 13 mol\% 5 ). 


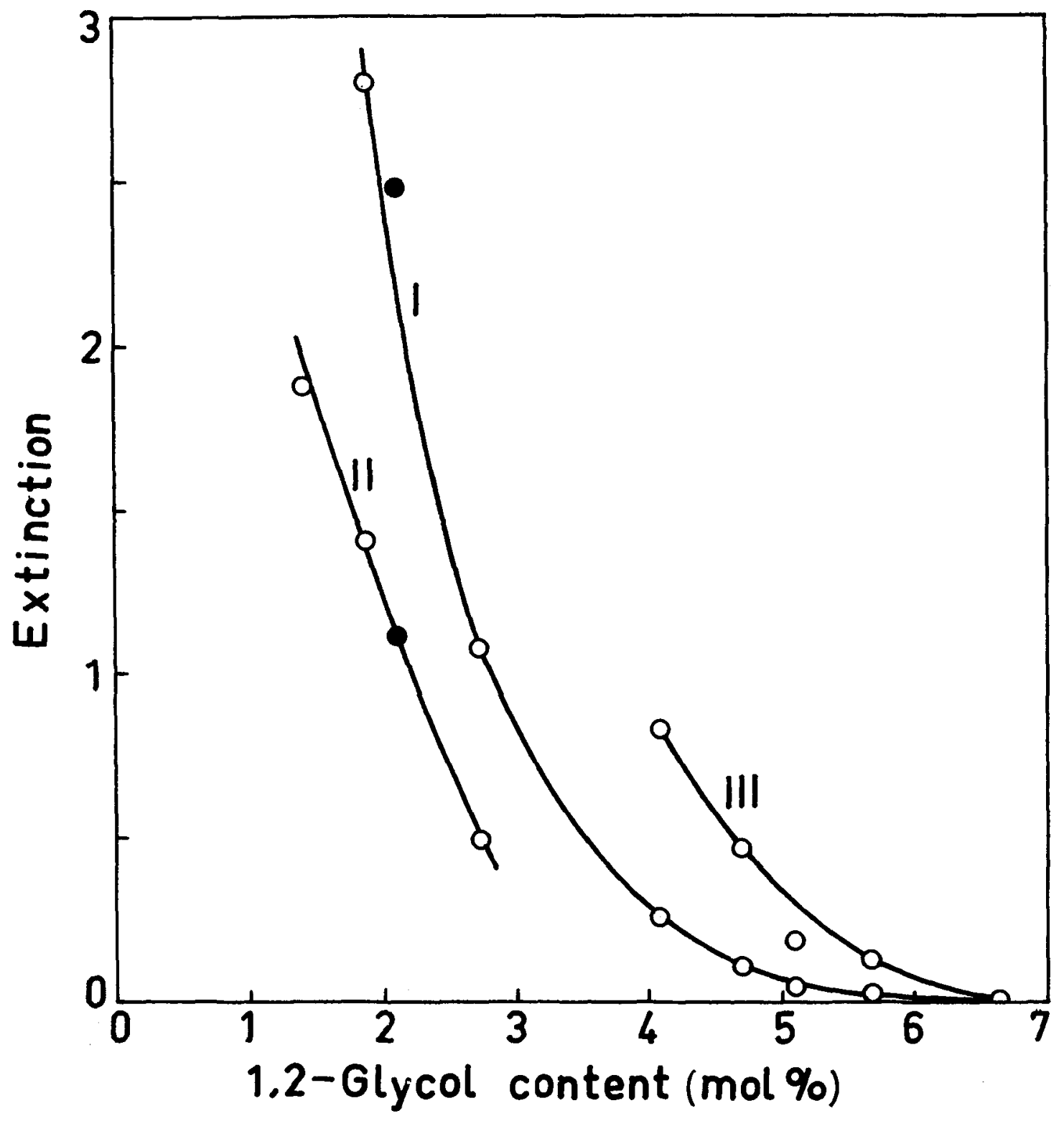

Figure 2. Effect of 1,2-glycol on PVA-iodine reaction

$O$ : Samples from the vinyl acetate-divinyl carbonate copolymer

- : Commercial PVA

Reaction conditions for 1,11 , and 111 are listed in Table 1. 


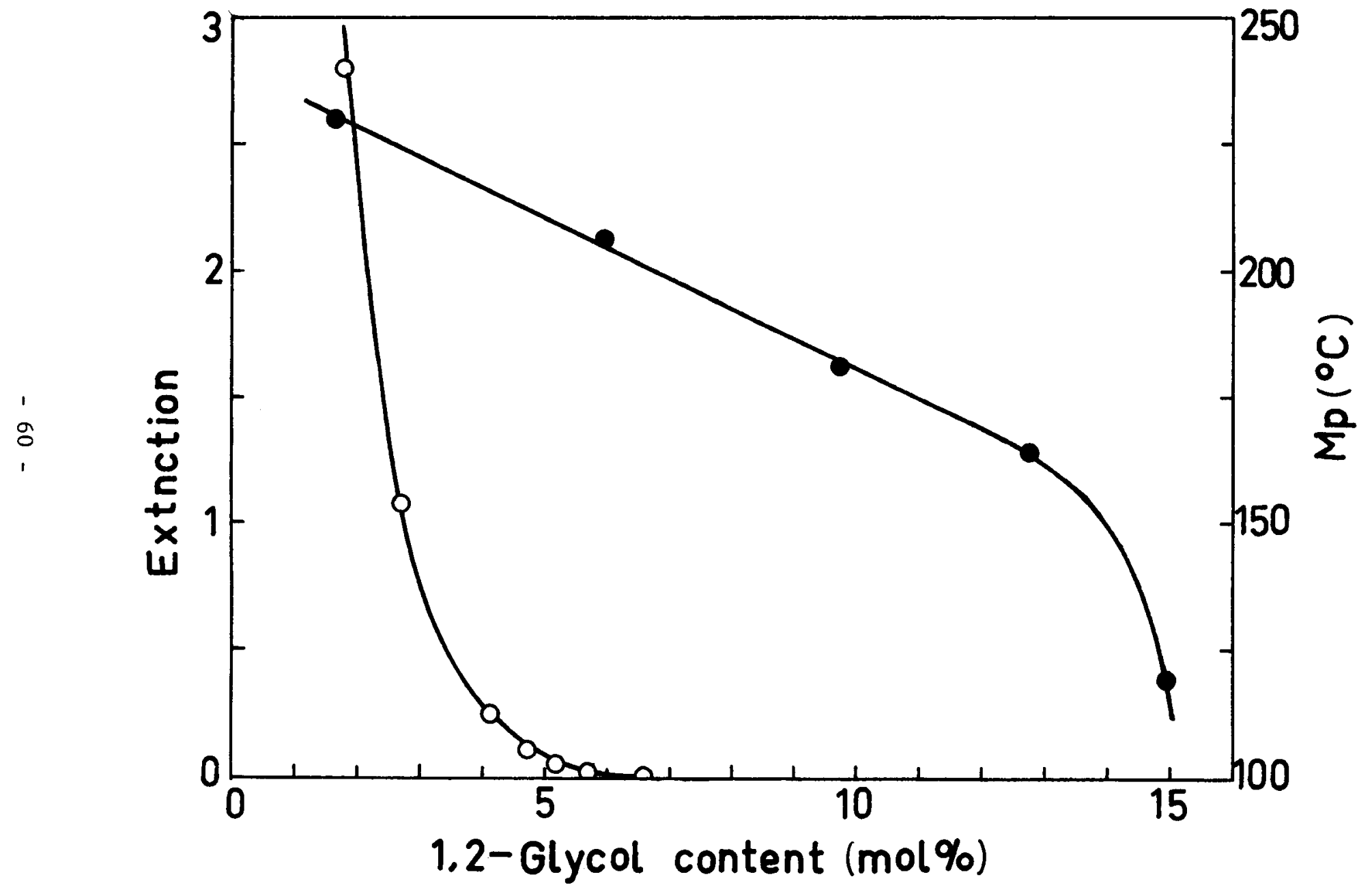

Figure 3. Effect of 1,2-alyccl structure on PVA-icdine reaction (O) and on meltina point of PVA( ) 
Whereas the PVA-iodine reaction suffers a large effect from much smaller amount of the 1,2-glycol content. This tendency was remarkable at a reaction temperature of $20^{\circ} \mathrm{C}$ which was employed by Shibatani and others ${ }^{4)}$. The difference in these two properties suggests that the PVA-iodine reaction requires a longer $1,3-$ glycol sequence length than does the crystallization of PVA.

Let us assume that a sequence leneth $n$ of 1,3-elycol units is required for the color reaction. If one assumes that the 1,2-glycol units are distributed statistically along the chain, the probability of the occurrence of sequence length $x$ of $1,3-$ Elycol units is obtained approximately by the formula,

$$
P(x)=\left(\frac{a+1}{N}\right)\left(\frac{b-1}{N}\right)^{x}
$$

where $\mathrm{N}$ is defree of polymerization, $a$ and $\mathrm{b}$ are average numbers of 1,2- and 1,3-glycol units in polymer molecules, respectively, that is $a+b=N$. Therefore the mole fraction of the 1,3-glycol units which are contained in sequences with more than $n, f(n)$, is obtained by the formula,

$$
f(n)=1-\frac{\sum_{x=1}^{n} x P(x) d x}{\sum_{x=1}^{\infty} x P(x) d x}
$$

Combination of Eq.I and Eq.2 gives Eq.3, which can be calculated assuming various $n$ values.

$$
f(n)=\left(\frac{b-1}{N}\right)^{n-1}\left(\frac{n-1 / \ln \left(\frac{b-1}{N}\right)}{1-1 / \ln \left(\frac{b-1}{N}\right)}\right)
$$

Table VII shows the mole fraction of the 1,3-glycol units with 
Table VII. Mole fraction of the 1,3-glycol units contained in sequences of more than $n$.

The values in parentheses are relative values taking No.3 as a standard.

\section{Sample}

No.

$D_{\max } n=100 \quad n=120 \quad n=150$

\begin{tabular}{lllll}
\hline 1 & - & $0.522(2.92)$ & $0.425(3.83)$ & $0.305(5.87)$ \\
2 & $2.8(2.6)$ & $0.378(2.11)$ & $0.279(2.52)$ & $0.174(3.35)$ \\
3 & $1.08(1.00)$ & $0.179(1.00)$ & $0.111(1.00)$ & $0.052(1.00)$ \\
5 & $0.26(0.24)$ & $0.046(0.25)$ & $0.020(0.18)$ & $0.0056(0.11)$ \\
6 & $0.11(0.10)$ & $0.024(0.14)$ & $0.0091(0.082)$ & $0.0021(0.040)$ \\
7 & $0.048(0.045)$ & $0.015(0.083)$ & $0.0051(0.046)$ & $0.00098(0.019)$ \\
8 & $0.026(0.024)$ & $0.0073(0.041)$ & $0.0023(0.021)$ & $0.00035(0.007)$ \\
10 & $0.009(0.008)$ & $0.0022(0.012)$ & $0.0005(0.004)$ & $0.00005(0.0009)$ \\
\hline
\end{tabular}


$n=100,120$ and 150 in the PVAs of different 1,2-glycol content. In order to facilitate a comparison between the observed extinctIon and the calculated value, sample No.3 was taken as a standard. In Figure 4, curves represent relations between the calculated relative amount of the 1,3-glycol units contained in sequences of more than $n$ and the $1,2-$ glycol content, showing a good correspondence between the observed and the calculated value when $n=120$. Namely, the conditions of the PVA-iodine reaction supposingly require an extremely long 1,3-glycol sequence length of atactic configuration. The value of 120 in $1,3-g l y c o l$ sequence length obtained here does not directly relate to the PVA-iodine complex, because other factor than the 1,2-8lycol structure may influence the PVA-iodine reaction. Thus an extremely long sequence length may be necessary in case of the atactic PVA. Indeed, syndiotactic PVA has high coloring ability in spite of low degree of polymerization ${ }^{4}$ ).

In order to check the effect of vicinal arrangement of hydroxyl groups, a comparison between the influence of the 1,2,3triol structure on the PVA-iodine reaction (closed circle) and that of 1,2-glycol (open circle) was made in Figure 5. This figure indicates that the effect of the 1,2-glycol structure inevitably gives the 1,4-glycol structure and both the structures probably infavor the color reaction, while the 1,2,3-triol structure does not give the 1,4-glycol structure. Thus it is not the vicinal arrangement of oH groups but the structural irregularity that influences the color reaction. Shibatani et al. 


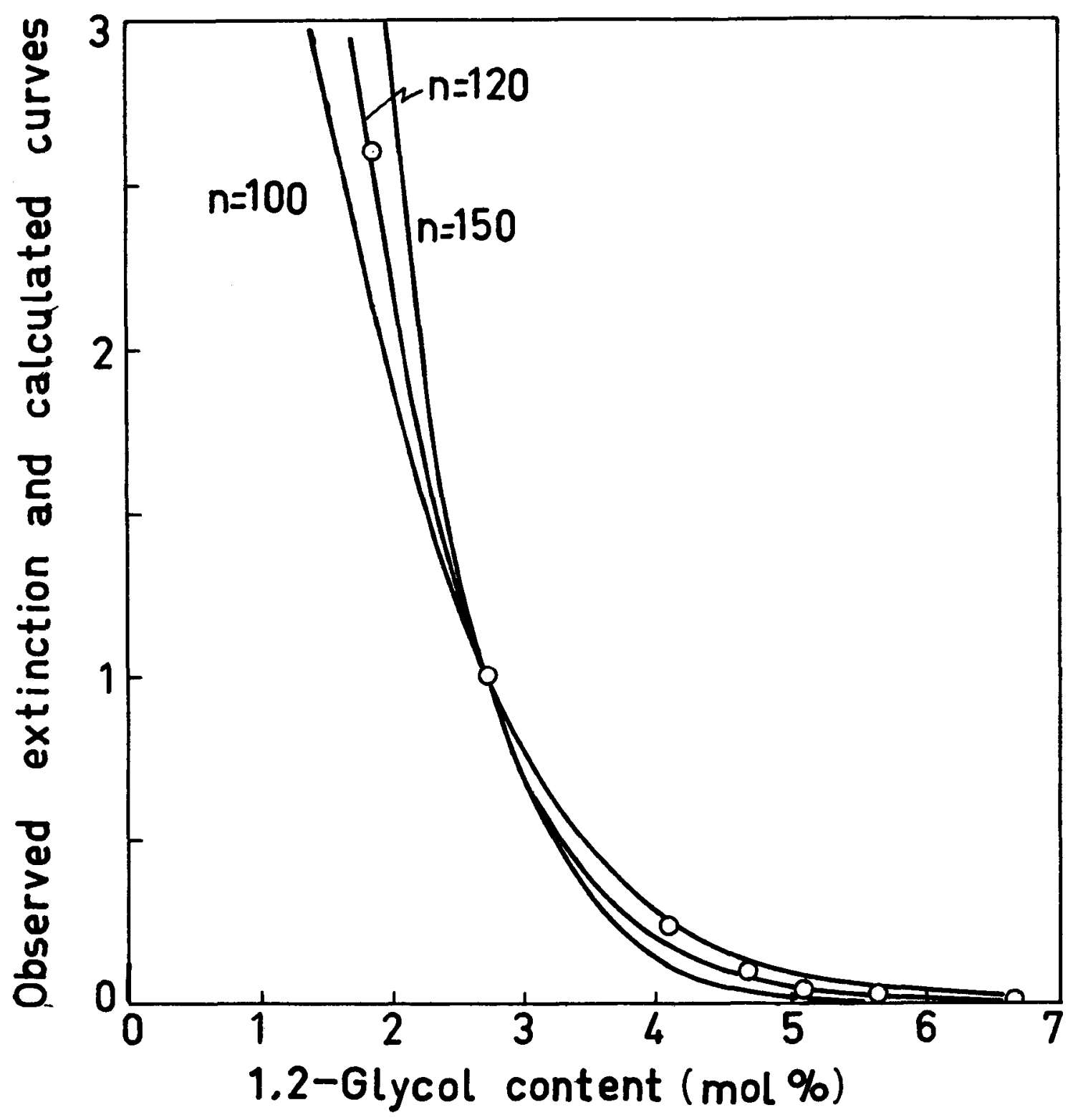

Figure 4. Relation between the calculated relative amounts of the 1,3-glycol uniys contained in sequences of more than $n$ and the 1,2glycol content. Curves represent the calculated values and circles the observed values. 


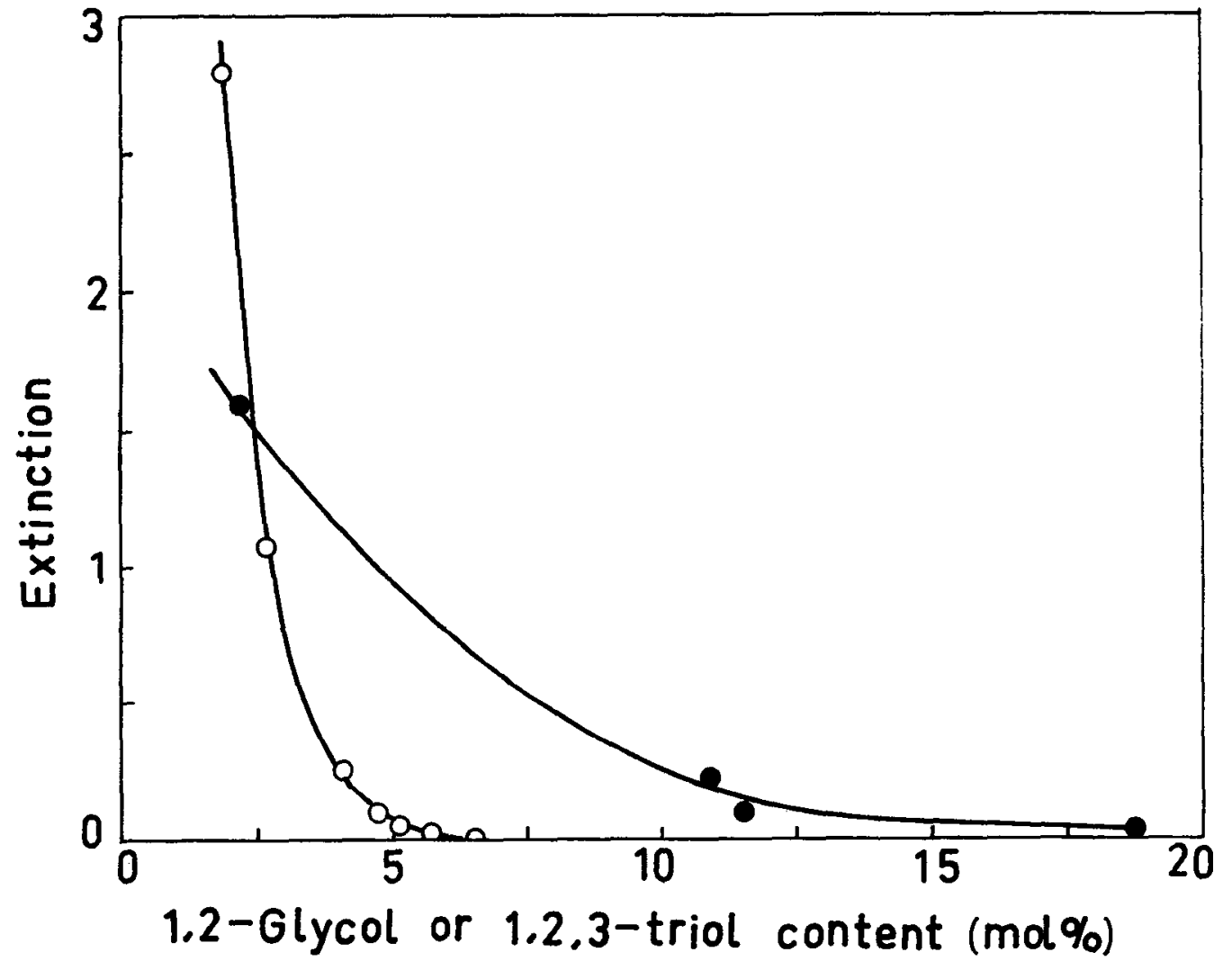

Figure 5. Effect of 1,2,3-triol structure on PVA-iodine reaction

- : Effect of 1,2,3-triol structure. 'PVAJ $=25 \mathrm{mmol} / 1,\left[\mathrm{I}_{2}\right]=1.25 \mathrm{mmol} / \mathrm{l}$, $[\mathrm{K} /]=2.5 \mathrm{mmol} / 1,6-8{ }^{\circ} \mathrm{C}, 20 \mathrm{hrs}$.

$O$ : Effect of 1,2-glycol structure. [PVAJ $=30 \mathrm{mmol} / 1$, other conditions are the same as above. 
have carried out a similar experiment and falled to obtain a difference between the 1,2-81ycol and 1,2,3-triol structures ${ }^{4)}$. It is conceivable that, as compared to our experiment, the reaction temperature was $\mathrm{high}$ and so the formation of the PVA-iodine complex was more difficult. The Effect of the Stereoregularity on the PVA-Iodine Reaction PVA samples (No.21-30) derived from vingl trimethylsilyl ether are known to contain negligibly small amount of 1,2-Elycol unit $^{1)}$. The influence of stereoregularity on the PVA-1odine reaction is also remarkable. The results in Tables $V$ and $V I$ show that PVA with syndiotacticity larger than 50\% showed high coloring ability and PVA samples with syndiotacticity less than $30 \%$ do not show the color reaction. It is characteristic to PVA samples with syndiotacticity of about $40 \%$ that the increase in the 1sotactic structure results in the shift of the absorption maximum as well as the decrease in extinction. This fact is in contrast with the effect of the 1,2-8lycol structure on the PVA-iodine reaction, and suggests that the effect of stereoregularity may be different qualitatively from that of the 1,2-glycol structure, that is, the isotactic structure may have an influence on the structure of the PVA-iodine complex. The tendency of the isotactic PVA to form an intramolecular hydrogen bonding 8 ) may reflect on the PVA-iodine reaction.

The similarity of the PVA-iodine reaction to the amyloselodine reaction suggests that the blue color may be due to the 
interaction between polyiodine, $\mathrm{I}_{\mathrm{n}}^{\mathrm{m}-}$, and oxygen atoms of surrounding PVA chains 9,10,11). The structure and the amount of the site which stabilizes polyiodine may change the absorption maximum and extinction. In case of the amylose-iodine reaction, this structure is determined as a helix; in case of the PVA-iodine reaction it is not clear although a helical structure was suggested by Zwick ${ }^{10)}$.

Imai et al. 3) and Shibatani et al. 4) have shown that the PVA-iodine reaction has a close relation with the intermolecular interaction of PVA. Since an isotactic sequence interferes with the formation of the intermolecular hydrogen bonding, a blue shift of the absorption maximum with increasing isotacticity may be due to the fact that intramolecular hydrogen bonding reduces the interaction between polyiodine and oxygen atoms of PVA. But the sequence length forming an intramolecular hydrogen bonding is not so long to destroy the complex completely at these medium isotacticity.

The addition of boric acid generally promotes the PVA-iodine reaction and shifts the absorption maximum to a longer wave length $(670-700 \mathrm{~m} \mu)$. Boric acid may intensify the intermolecular Interaction of PVA and consequently may promote the interaction between PVA and iodine. Without boric acid, the color reaction was not observed on samples No.2l and 22. The addition of boric acid to these developed the color, but the visible absorptions are too braad to determine the absorption maximum. It is interesting 
to note that a sample which is rich in isotactic structure(No.21, $88 \%$ 1sotacticity) was colored more intensely than No.22( $80 \%$ isotacticity). Sample No.21 is less soluble in water than No.22, which is the most soluble among various tacticities, and some other kind of intermolecular interaction than hydrogen bonding was suggested ${ }^{l)}$. The intermolecular interaction is reinforced by boric acid probably at the segments not having intramolecular hydrogen bondings, resulting in the formation of the PVA-iodine complex. The broad absorption spectrum also suggests that this interaction may not be so simple as the interaction in atactic or syndiotactic PVA.

The comparison between the influence of stereoregularity on the PVA-iodine reaction ind that of the 1,2-5lycol structure is summed up as follows: the existence of 1,2-glycol structure discontinues the interaction between PVA and iodine, but does not influence the structure of PVA-iodine complex. The isotactic structure may modify the structure of the PVA-iodine complex so as to weaken the interaction, finally entirely suppressing the complex formation at isotacticity higher than $70 \%$

\section{Acknowledgment}

The authors are deeply indebted to Dr M. Sumi for the many helpful suggestions and discussions in relation to this work. 
References

1. M. Sumi, K. Matsumura, R. Ohno, S. Nozakura and S. Murahashi, Kobunshi Kagaku, 24, 606(1967), S. Murahashi, S. Nozakura, K. Matsumura, J. Polym. Sci., B4, 59(1966)

2. K. Kikukawa, S. Nozakura and S. Murahashi, Kobunshi Kagaku, 24, $811(1967)$

3. K. Imai and M. Matsumọto, J. Polym. Sci., 25, 335(1961)

4. K. Shibatani, M. Nakamura and Y. Oyanagi, Kobunshi Kagaku, 26, $118(1969)$

5. K. Kikukawa, S. Nozakura and S. Murahashi, Kobunshi Kagaku, 25, $19(1968)$

6. H.E. Harris and J.G. Pritchard, J. Polym. Sci.,A2, 3673(1961)

7. S. Murahashi, S. Nozakura, M. Sumi, H. Yuki and K. Hatada, J. Polym. Sci.,B4, 65(1966), Kobunshi Kagaku, 23, 605(1966) 8. S. Murahshi, H. Yuki, T. Sano, U. Yonemura, H. Tadokoro and Y. Chatani, J. Polym. Sci.,62, 577(1962)

9. H. Murakami, J. Chem. Phys.,22, 367(1954)

10. M.M. Zwick, J. Appl. Polym. Sci.,2, 2393(1965)

11. F.R. Senti and S.R. Erlander, Non-stoichiometric Compounds, L. Mandelcorn Ed.,(Academic Press, New York, 1964) p.568 


\section{Chapter III}

Poly (vinyl alcohol)-Iodine Reaction of Poly (vinyl alcohol) fractionated by Foaming

Synopsis

It has been confirmed that foam fractionation of an aqueous poly(vinyl alcohol) solution produced poly(vinyl alcohols) with different reactivity on the poly(vinyl alcohol)-iodine reaction, namely the color intensity decreased with increase in the fraction number. This result was found not only with a poly(vinyl alcohol) derived from poly(vinyl acetate), but also with a specimen derived from cationically polymerized poly(vinyl trimethylsilyl ether). Particularly in the case of poly(vinyl alcohol) obtained from poly(vinyl acetate)(degree of polymerization $=1652$, syndiotacticity $=50.0 \%$ in $\mathrm{diad})$, the variation of color intensity among the fractions can not be explained by any one of the structural factors such as molecular weight, the 1,2-glycol structure, stereoregularity, and the carbonyl group in the main chain. Therefore an other molecular structure, for example short branching, which will affect the poly(vinyl alcohol)-iodine reaction and the foam fractionation should be considered. 
The result also indicates the homogeneity of poly(vinyl alcohol) from poly(vinyl acetate) with respect to stereoregularity and the 1,2-glycol structure contents. In the case of poly(vinyl alcohol) obtained from poly(vinyl trimethylsilyl ether) (degree of polymerization $=1496$, syndiotacticity $=37.5 \%$ in diad), the fractionation with respect to stereoregularity has occurred: syndiotacticity of poly(vinyl alcohol) contaned in foam layers was higher than that in the residual solution. This result indicates that the poly(vinyl alcohol) derived from poly (vinyl trimethylsilyl ether) consisted of stereoblock and/or a mixture of poly(vinyl alcohol) of different tacticity.

\section{Introduction}

Imai et al. sepatated a poly(vinyl alcohol)(PVA) derived from radically polymerized poly(vinyl acetate)(PVAc) into fractions by foaming an aqueous solution ${ }^{1)}$. The fractions showed different reactivity in the PVA-iodine reaction though there is little difference in degree of polymerization and in the 1,2-glycol content. They suggested that PVA was fractionated according to stereoregularity. But there arises a question in considering the presence of wide difference of stereoregularity amone individual polymer molecules of a radical polymer.

It is known that even a minor change in molecular structure 
Of PVA influences the properties of PVA. Factors, which may affect crystallinity and PVA-iodine reaction, involve the 1,2glycol structure, the carbonyl group in the main chain, branching and stereoregularity. Since the method of determination of stereoregularity was established ${ }^{2)}$, PVA samples with different stereoregularities have been prepared in order to study the effect of stereoregularity on properties of PVA ${ }^{3)}$. The increase of isotacticity of PVA loweres melting point, crystallinity, and color intensity of the PVA-iodine reaction $3,4,5)$. Murahashi et al. showed that the increase of the 1,2-glycol structure deteriorates the crystallinity ${ }^{4)}$ and fades the color of the PVA-iodine reaction ${ }^{5)}$. In addition, Shibatani et. al. have shown that a minor change in 1,2-glycol contents remarkably affects the PVAiodine color reaction ${ }^{6)}$.

This work was undertaken to investigate the properties of PVA fractionated by foaming in detail, and to elucidate the effect of the change in the molecular structure of PVA on the PVA-iodine reaction and on the foam fractionation. Foam fractionation of PVA derived from cationically polymerized poly(vinyl trimethylsilyl ether)(poly(VOSi)) which was nearly atactic, was also investigated. 


\section{Experimental}

\section{PVA Samples}

Sample A was a commericial PVA(Kuraray Co., Ltd.) which was derived from radically polymerized PVAC. Degree of polymerization $=1652$, residual acetate group $=0.23 \%$, sodium acetate $=0.25 \%$, syndiotacticity $=50.0 \%$ in diad, the $1,2-$ glycol content $=2.12 \%$.

Sample B was prepared by methanolysis of a poly(VOSi) prepared from the cationic polymerization of VOSi. The polymerization procedure was as follows: a mixture of $200 \mathrm{ml}$ of VOSi, $1000 \mathrm{ml}$ of methylene chloride, and $800 \mathrm{ml}$ of toluene was placed in a 21 three-necked flask under a nitrogen atomosphere, the flask was then cooled to $-70^{\circ} \mathrm{C}$ with a dry ice-methanol bath. When ethylaluminum dichloride $(0.7 \mathrm{ml})$ was added slowly to the flask under stirring, the reaction temperature rose temporally to $-50^{\circ} \mathrm{C}$, and then the solution was stirred for two hours at $-70^{\circ} \mathrm{C}$. The polymerization mixture was poured into a large amount of methanol. Methanolysis of the resulting polymer and precipitation of PVA occurred simultaneously. The PVA was washed several times with methanol by decantation and separated by filtar tion and dried under vacuum. Yield was $52.0 \mathrm{~g}(91 \%)$. Degree of polymerization = 1496, syndiotacticity $=37.5 \%$ in diad, the $1,2-$ glycol content $=0.25 \%$.

\section{Foam Fractionation}

Sample A: a solution of $60 \mathrm{~g}$ of PVA and 31 of water was placed in a 51 wide-mouthed bottle. The bottle was shaken at a 
frequency of 68 cycle per minute: a foam layer was thus created. After being shaken for apropriate period, the soultion was allowed to stand for a certain time. In the course of this standing, part of the foam usually disintegrated and the remaining foam layer was taken out as a foam cake. The residual solution was usually cloudy, and there was a slight amount of precipitate at the bottom of the bottle. To obtain successive fractions, the cloudy solution was heated until it became completely clear and then the procedure involving shaking, standing, separation and heating was repeated.

Sample B: fractionation procedure was the same as the above except for the use of $40 \mathrm{~g}$ of PVA and 21 of water.

\section{PVA-Iodine Color Reaction}

An aqueous PVA solution was mixed with a $\mathrm{KI}-\mathrm{I}_{2}$ solution at $6 \sim 8^{\circ} \mathrm{C}$ and kept at this temperature for 23 hrs. The mixture was subjected to spectroscopic measurement at room temperature using a Hitachi spectrophotometer, EPS-3T.

Sample A: $[\mathrm{PVA}]=15 \mathrm{mmol} / 1,\left[\mathrm{I}_{2}\right]=1.25 \mathrm{mmol} / 1,[\mathrm{KI}]=5 \mathrm{mmol} / 1$.

Sample B: $[\mathrm{PVA}]=30 \mathrm{mmol} / 1,\left[\mathrm{I}_{2}\right]=1.25 \mathrm{mmol} / 1,[\mathrm{KI}]=5 \mathrm{mmol} / 1$.

\section{Characterization of PVA}

Degree of polymerization of PVA was calculated from viscosity of 1\% aqueous PVA solution at $30^{\circ} \mathrm{C}$ according to the equation presented by Nakajima et al 7). 
Diad syndiotacticity of PVA was calculated from the absorbance ratio, $D_{916} / D_{849}$, of the IR spectra of PVA films, which was prepared from $1 \%$ aqueous solution and dried at $30^{\circ} \mathrm{C}$ in a silica gel desiccator, according to the following equation presented by Murahashi et al.2)

$$
\text { s(diad) } \%=72.4\left(D_{916} / D_{849}\right)^{0.43}
$$

The content of $1,2-81 y \operatorname{col}$ structure was determined by titrating the periodic acid consumption by PVA in accordance with the nethod of Harris et al. ${ }^{8}$ ) In the cass of Sample B, the content was also determined by degree of polymerization of PVA oxydized by periodic acid in accordance with the method of Flory ${ }^{9}$.

The carbonyl group in main chain was measure by the UV spectra of aqueous PVA solutions. Absorption maxima at $240 \mathrm{~m} \mu$ and $280 \mathrm{~m} \mu$ are assighned to $-\mathrm{C}-\mathrm{C}=\mathrm{C}$, and $-\mathrm{C}-\mathrm{C}=\mathrm{C}-\mathrm{C}=\mathrm{C}$, respectively ${ }^{10}$ ).

\section{Results}

The results of foam fractionation of Sample A and Sample B are given in Table I and II, reaspectively. Sample A produced stable foams and thus gave a large number of fractions, whereas Sample B produced less stable foams and most of the sample remained in solution. The change of the various properties of PVA according to the fractionation are given in Table III and IV. 
Table I. Foam fractionation of Sample A

\begin{tabular}{|c|c|c|c|c|}
\hline \multirow{2}{*}{$\begin{array}{c}\text { Fraction } \\
\text { No. }\end{array}$} & \multirow{2}{*}{$\begin{array}{l}\text { Shaking } \\
\text { time, hr, }\end{array}$} & \multirow{2}{*}{$\begin{array}{l}\text { Standing } \\
\text { time, hr, }\end{array}$} & \multicolumn{2}{|c|}{ Yield } \\
\hline & & & $\mathbf{B}$, & $\%$ \\
\hline A 1 & 18 & 5 & 3.09 & 5.15 \\
\hline A 2 & 18 & 5 & 3.77 & 6.28 \\
\hline A 3 & 18 & 5 & 3.68 & 6.13 \\
\hline A 4 & 21 & 24 & 3.72 & 6.20 \\
\hline A 5 & 21 & 24 & 4.25 & 7.08 \\
\hline A 6 & 21 & 24 & 3.72 & 6.20 \\
\hline A 7 & 23 & 24 & 2.84 & 4.73 \\
\hline A 8 & 21 & 24 & 3.58 & 5.97 \\
\hline A 9 & 21 & 24 & 1.85 & 3.08 \\
\hline A 10 & 21 & 24 & 2.26 & 3.77 \\
\hline A 11 & 24 & 45 & 1.42 & 2.37 \\
\hline A 12 & 24 & 45 & 1.52 & 2.53 \\
\hline A 13 & 24 & 45 & 1.09 & 1.82 \\
\hline A 14 & 24 & 45 & 0.85 & 1.42 \\
\hline A 15 & 24 & 45 & 0.61 & 1.02 \\
\hline A 16 & 24 & 45 & 0.57 & 0.95 \\
\hline A 17 & 24 & 45 & 0.74 & 1.23 \\
\hline A 18 & 24 & 45 & 0.56 & 0.93 \\
\hline$A-R^{a)}$ & - & - & 16.90 & 28.17 \\
\hline
\end{tabular}

a) Residual PVA in solution 
Table II. Foam fractionation of Sample B

\begin{tabular}{ccccc} 
Fraction & Shaking & Standing & \multicolumn{2}{c}{ Yield } \\
No. & time, hr, & time, hr, & $\mathrm{g}$, & $\%$, \\
\hline B 1 & 10 & 24 & 0.308 & 0.91 \\
B 2 & 20 & 48 & 1.030 & 2.56 \\
B 3 & 20 & 24 & 0.890 & 2.21 \\
B 4 & 20 & 24 & 0.599 & 1.48 \\
B 5 & 20 & 48 & 0.503 & 1.25 \\
B 6 & 20 & 24 & 0.320 & 0.79 \\
B 7 & 20 & 24 & 0.402 & 1.00 \\
B 8 & 20 & 24 & 0.308 & 0.76 \\
B 9 & 20 & 24 & 0.240 & 0.69 \\
B 10 & 20 & 48 & 0.111 & 0.27 \\
B 11 & 20 & 48 & 0.245 & 0.60 \\
B 12 & 20 & 48 & 0.126 & 0.31 \\
B-R & - & - & 35.24 & 88.0 \\
\hline
\end{tabular}

a) Residual PVA in solution 
Table III. Structure and Properties of Foam-fractionated Sample A

\begin{tabular}{|c|c|c|c|c|c|}
\hline Fraction & DP & Syndiotac- & $1,2-$ glycol & UV spectra $\left.{ }^{2}\right)$ & ${\mathrm{PVA}-\mathrm{I}_{2} \text { reaction }}^{\mathrm{b})}$ \\
\hline No. & & ticity, \%, & mol\%, & $d_{230}$ & $\lambda_{\max }, m \mu$ \\
\hline
\end{tabular}

\begin{tabular}{|c|c|c|c|c|c|c|}
\hline$A O^{C)}$ & 1652 & 50.0 & 2.12 & - & 1.79 & 614 \\
\hline A 1 & 2060 & 53.0 & 2.14 & 2.5 & 3.23 & $" 1$ \\
\hline A 2 & 1974 & 50.0 & - & 1.8 & 3.28 & $"$ \\
\hline A 3 & 1991 & 50.0 & - & 2.7 & 3.07 & $"$ \\
\hline A 4 & 2349 & 50.5 & 2.07 & 1.9 & 3.30 & $"$ \\
\hline A 5 & 2384 & 51.0 & - & 1.3 & 3.20 & $"$ \\
\hline A 6 & 2256 & 51.5 & - & 1.5 & 2.87 & $"$ \\
\hline A 7 & 2371 & 52.0 & 2.03 & 0.77 & 2.70 & $"$ \\
\hline A 8 & 2509 & 49.0 & - & 0.72 & 2.47 & $"$ \\
\hline A 9 & 2173 & 51.0 & - & 0.94 & 2.13 & $" 1$ \\
\hline A 10 & 2193 & 50.0 & 2.00 & 0.71 & 1.96 & $"$ \\
\hline A 11 & 1879 & 49.0 & - & 0.83 & 1.51 & $" 1$ \\
\hline A 12 & - & 49.5 & - & 0.86 & 1.07 & $"$ \\
\hline A 13 & 1524 & 49.0 & 1.98 & 0.85 & 0.84 & $"$ \\
\hline A 14 & 1583 & 49.5 & - & 1.4 & 0.79 & $"$ \\
\hline A 15 & 1571 & 48.5 & - & 0.61 & 0.76 & $"$ \\
\hline A 16 & 1490 & 49.0 & 2.05 & - & 0.44 & $"$ \\
\hline A 17 & 1450 & 49.0 & - & 0.51 & 0.40 & $"$ \\
\hline A 18 & 1168 & 48.5 & - & - & 0.31 & $"$ \\
\hline$A-R^{d)}$ & 743 & 48.5 & 2.13 & - & 0.06 & $"$ \\
\hline
\end{tabular}

a) Aqueous PVA solution $(0.6 \%), \lambda_{\max }=230 \mathrm{~m} \mu$

b) Reaction conditions; [PVA] $=15 \mathrm{mmol} / 1,\left[I_{2}\right]=1.25 \mathrm{mmol} / 1$,

$[\mathrm{KI}]=5 \mathrm{mnol} / \mathrm{h}$ at $6 \sim 8^{\circ} \mathrm{C}$ for $23 \mathrm{hrs}$

c) Original unfractionated PVA

d) Residual PVA in solution 
Table IV. Structure and Properties of Foam-fractionated Sample B

\begin{tabular}{|c|c|c|c|c|c|c|c|c|}
\hline \multirow{2}{*}{$\begin{array}{c}\text { Fraction } \\
\text { No. }\end{array}$} & \multirow[t]{2}{*}{ DP } & \multirow{2}{*}{$\begin{array}{l}\text { Syndiotac- } \\
\text { ticity, \% }\end{array}$} & \multirow{2}{*}{\multicolumn{2}{|c|}{$\begin{array}{c}1,2-81 y c o l \\
\text { mol } \%\end{array}$}} & \multirow{2}{*}{ UV } & \multirow{2}{*}{$\begin{array}{l}\left.\text { spectra }^{a}\right) \\
d_{240}\end{array}$} & \multicolumn{2}{|c|}{${\mathrm{PVA}-\mathrm{I}_{2} \text { reaction }}$} \\
\hline & & & & & & & $d_{\max }$ & $\lambda_{\max }$ \\
\hline$B O^{C)}$ & 1496 & 37.5 & $0.25^{\circ}$ &, $0.35^{f)}$ & & - & 0.216 & 596 \\
\hline B 1 & 1449 & 43.5 & . & . & & 2.62 & 1.542 & 602 \\
\hline B 2 & 1577 & 44.0 & 0.14 & 0.1 & & - & 1.484 & 602 \\
\hline B 3 & 1578 & 41.5 & . & - & & 1.10 & 1.411 & 605 \\
\hline B 4 & 1520 & 44.0 & . & • & & 1.91 & 1.352 & 606 \\
\hline B 5 & 1585 & 41.5 & - & 0.50 & & 0.82 & 1.159 & 606 \\
\hline B 6 & 1572 & 42.5 & . & • & & 0.98 & 1.081 & 606 \\
\hline B 7 & 1542 & 44.0 & . & 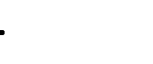 & & 1.33 & 0.753 & 608 \\
\hline B 8 & 1554 & 42.5 & . & . & & 0.84 & 0.735 & 606 \\
\hline B 9 & 1513 & 41.5 & . & • & & 0.74 & 0.674 & 606 \\
\hline B 10 & 1522 & 42.0 & . & 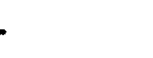 & & 0.96 & 0.953 & 605 \\
\hline B 11 & 1431 & 41.5 & . & • & & 0.83 & 0.383 & 601 \\
\hline B 12 & 1424 & 41.0 & . & - & & 0.80 & 0.413 & 597 \\
\hline$B-R^{d)}$ & 1490 & 38.0 & 0.40 & 0.58 & & - & 0.433 & 562 \\
\hline
\end{tabular}

a) Aqueous PVA solution $(0.6 \%), \lambda_{\max }=240 \mathrm{~m}$

b) Reaction conditions; $[\mathrm{PVA}]=30 \mathrm{mmol} / 1,\left[\mathrm{I}_{2}\right]=1.25 \mathrm{mmol} / 1$, $[\mathrm{KI}]=5 \mathrm{mmol} / \mathrm{I}$ at $6 \sim 8^{\circ} \mathrm{C}$ for $23 \mathrm{hre}$

c) Original unfractionated PVA

d) Residual PVA in solution

e) Determined by the viscometric method

f) Determined by the periodate method 
Figure 1 shows that the degree of polymerization of Sample A In each fraction was not constant but increased slightly with an increase in the fraction number and then decreased. On the other hand, the degree of polymerization of Sample B in each fraction was substantially constant.

There is little defference in the 1,2-glycol structure content of Sample A(Table III) and B(Table IV) in each fraction and a systematic change was not found.

As may be seen in Figure 2, the stereoregularity of Sample A in each fraction essentially unaltered within the experimental error and was the same as that of the original PVA. The syndiotacticity of Sample B contained in the foam layer is higher than that of the original PVA. Therefore Sample B was separated according to syndiotacticity, but there was not systematic change of stereoregularity among fractions.

The aqueous solutions of Sample A and Sample B exhibit their absorption maxima at about $230 \mathrm{~m} \mu$ (Sample A), $240 \mathrm{~m} \mu$ (Sample B) and $280 \mathrm{~m} \mu$ (weak), which were assigned to $\underset{0}{-C}-C=C$ and $-C-C=C-C=C$, respectively(Table III and IV ${ }^{10)}$. The relationship between the absorbance at $230 \mathrm{~m} \mu(240 \mathrm{~m} \mu$ for Sampl B) and the fraction number 1s depicted in Figure 3; there is no clear-cut dependence of the absorbance on the fraction number though the oarly fractions tend to absorb more intensely than the later fractions. The intensity of the PVA-iodine color reaction( $d_{\max }$ ) of Sample A and Sample B is shown in Figure 4. Systematic changes 


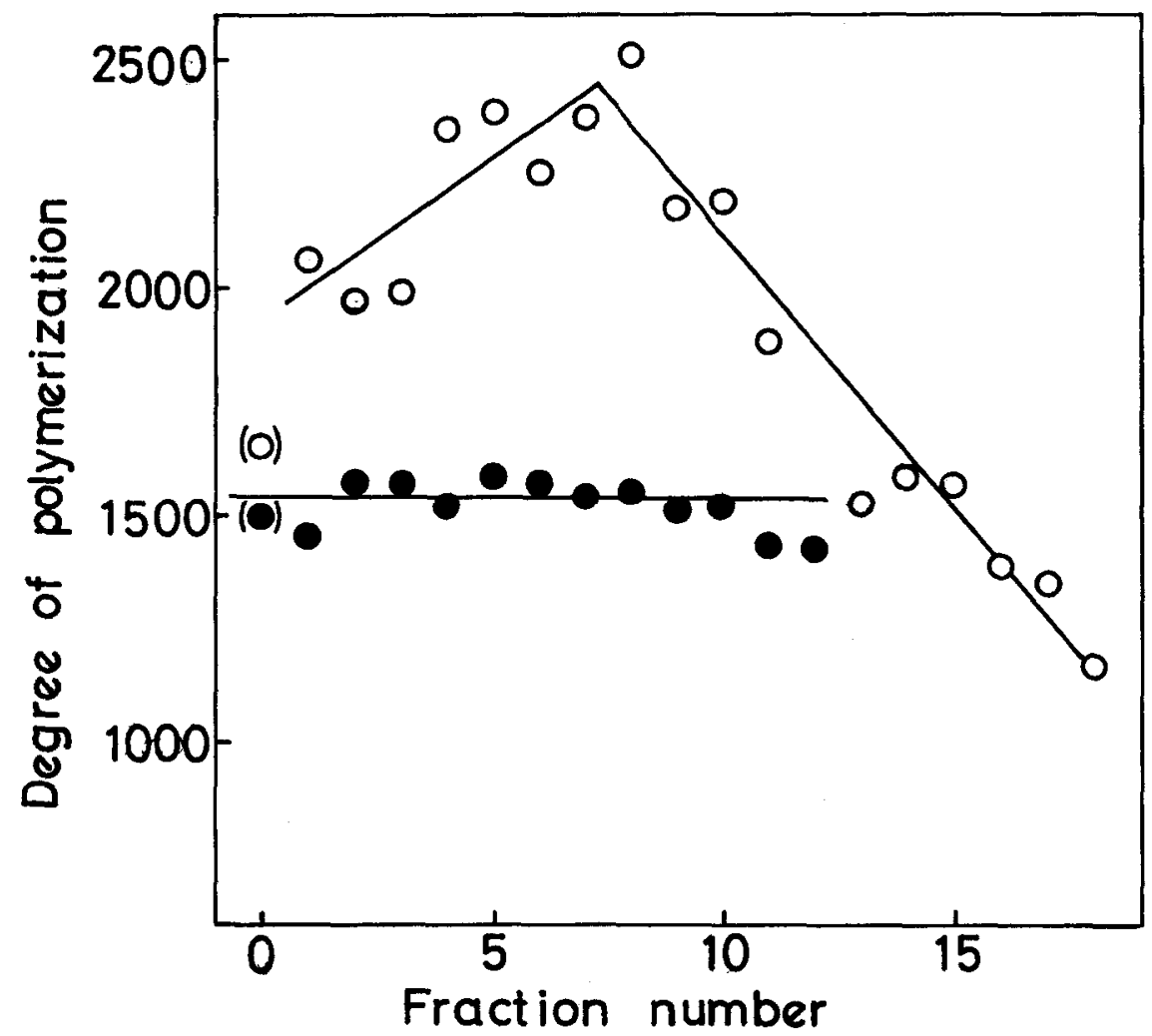

Figure 1. Degree of Polymerization of Fractions

O; Sample A

; Sample B

Plots in parentheses represent the original PVA 


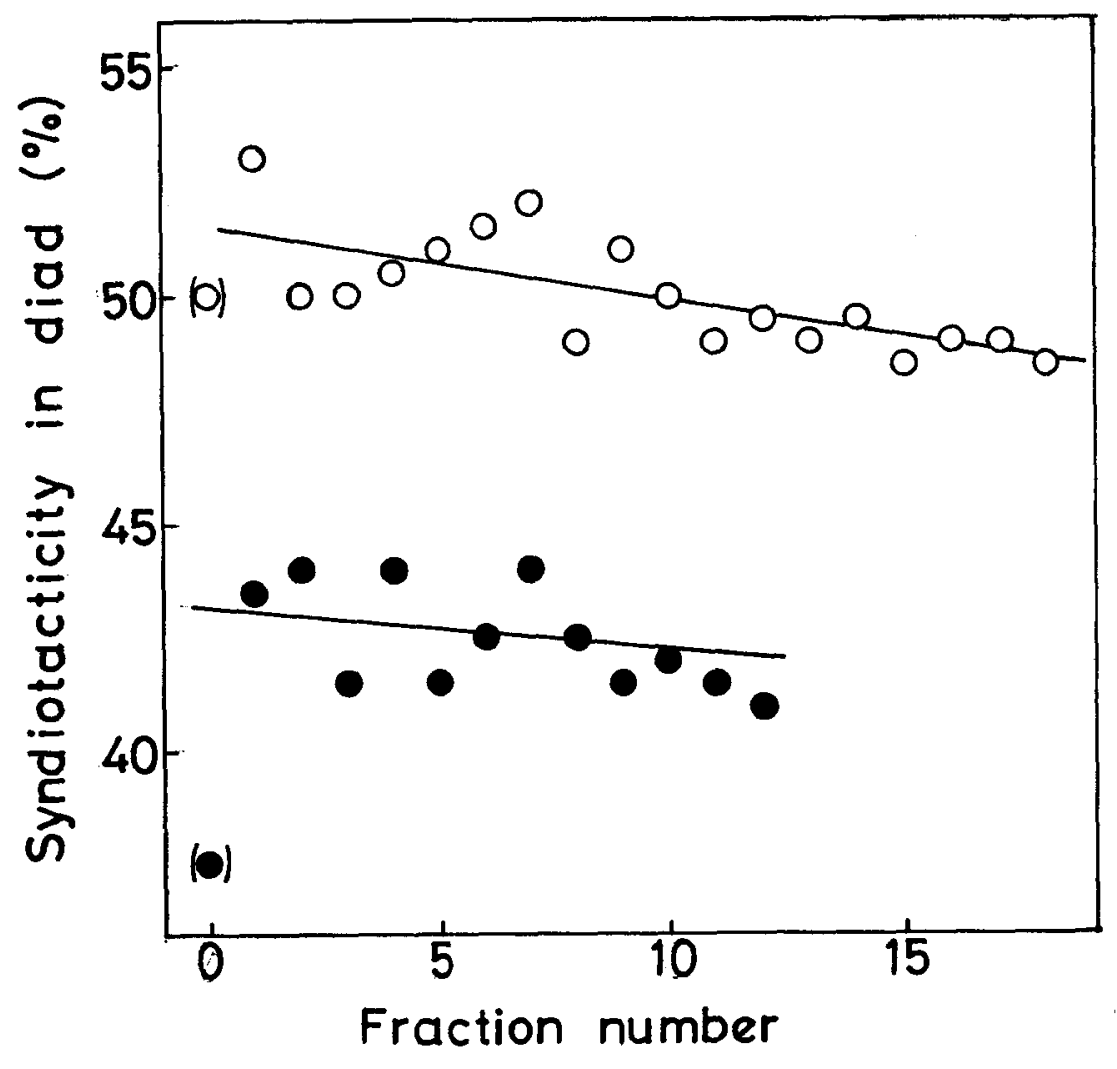

FIgure 2. Stereoregularity of Fractions

O; Sample A

- Sample B

Plots in parentheses represent the original PVA 


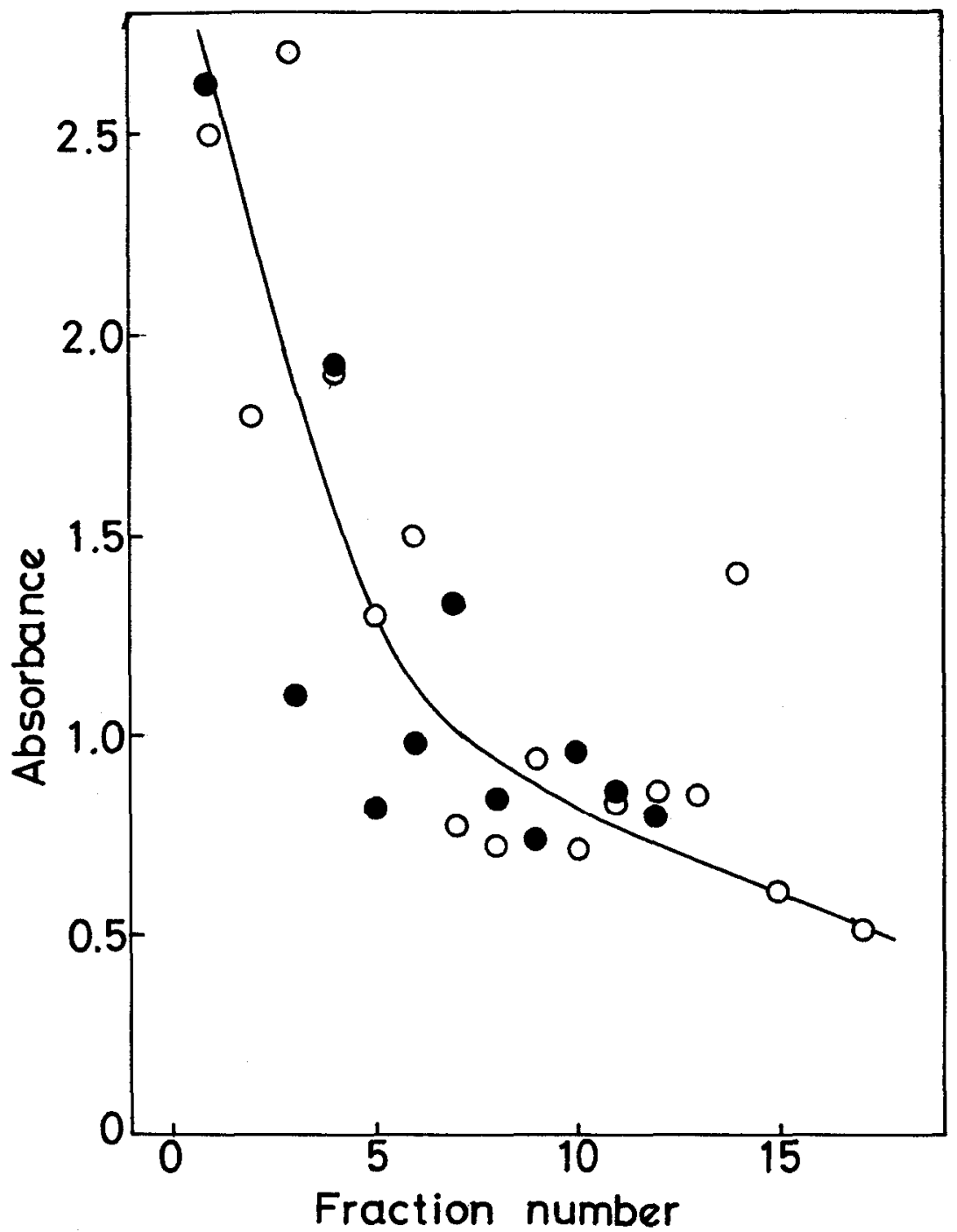

Figure 3. Absorbance at $230 \mathrm{~m} \mu$ (Sample A) and $240 \mathrm{~m} \mu$ (Sample B) of Aqueous Solution of

Fractions

O; Sample A

-; Sample B

$[\mathrm{PVA}]=0.6 \%$ in water 


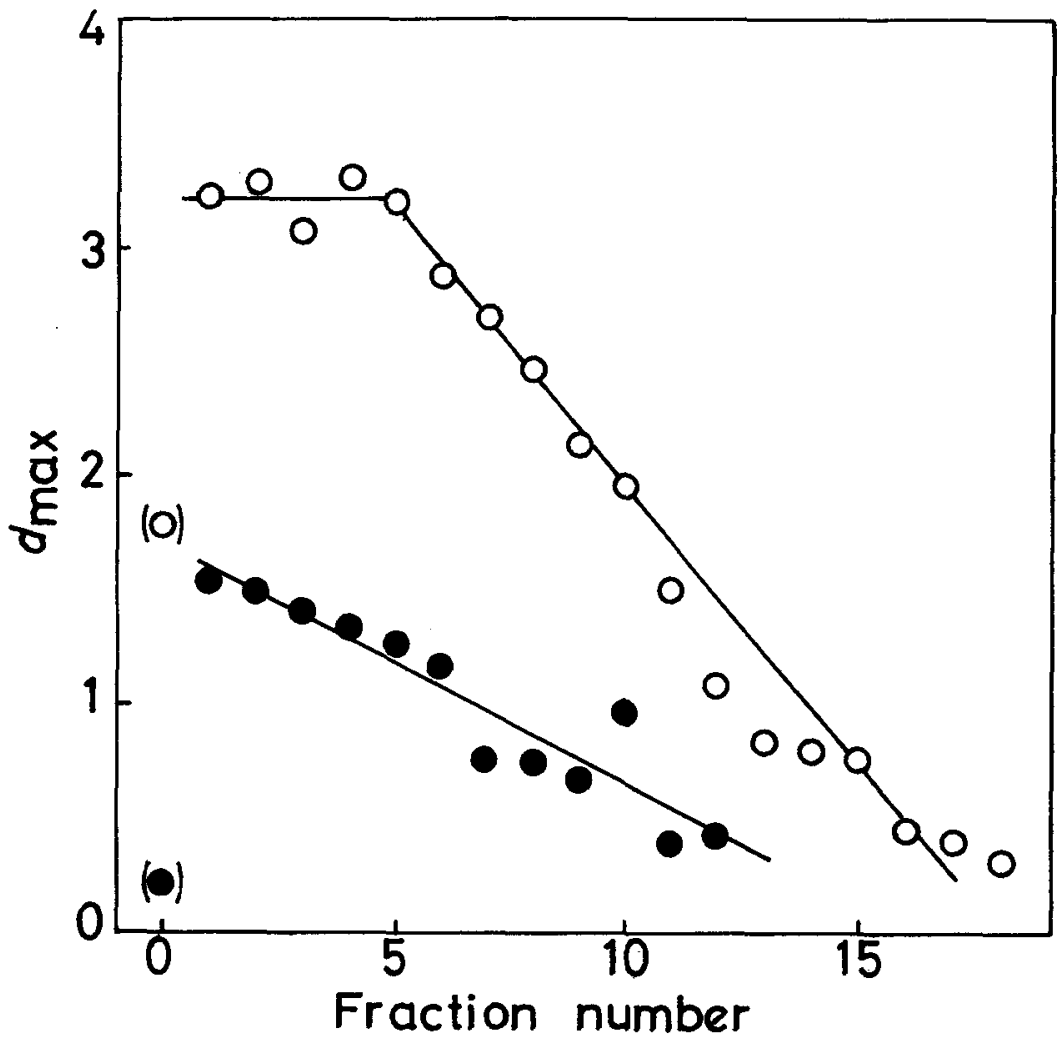

Figure 4. The Iodine-Color Reaction of Fractions

O; Sample A, [PVA] $=15 \mathrm{mmol} / 1,\left[\mathrm{I}_{2}\right]=1.25 \mathrm{mmol} / 1$, $[\mathrm{KI}]=5 \mathrm{nmol} / 1,6 \sim 8{ }^{\circ} \mathrm{C}, 23 \mathrm{hrs}$

- Sample B, [PVA] $=30$ mol/1, other conditions are the same as sample A

Plots in parentheses represent the original PVA. 
of $d_{\max }$ of Sample $A$ and $B$ in each fraction. was clearly found, that is, as the fractionation progresses, $d_{\max }$ decreases remarkably. It is characteristic to Sample B that the absorption maxima varied with fraction number as shown in Table IV.

\section{Discussion}

Foam fractionation in low molecular weight compounds takes advantage of adsorption of surface-active agents on interface and have found wide applications ${ }^{11}$ ). In the case of high molecular welght compounds such as protein, starch and synthetic high polymer, the foam is stabilized by the formation of films of a gel-like substance $e^{12}$. Viscosity of the solution also affects the stability of the foam. In the case of the solution of PVA, the formation of remarkably stable foam will suggest the gelation. Therefore the foam fractionation described here may be similar in principle to the mechanical denaturation of PVA solution reported by Go et al. ${ }^{13)}$ The above discussion suggests the possibility of the fractionation of PVA according to the molecular structure, which influence the tendency of gelation, such as stereoregularity, the 1,2-glycol content, the carbonyl group and branching.

As may be seen in rable III, IV and Figure 4, a characteristic result in the foam fractionation of a PVA solution was a decrease 
of the PVA-iodine color with an increase of fraction number. The PVA-iodine color reaction is strongly affected by molecular weight, stereoregularity, the 1,2-glycol structure of PVA as reported previously. The color reaction is also reported to correspond to the degree of swelling of PVA, which probably reflects the crystallinity.

Figure 1 shows that the degree of polynerization of Sample A is not constant but increase with an increase in the fraction number and then decrease, whereas that of Sample B is essentially constant, that is, the fractionation did not occur with respect to molecular weight. Imai et al. reported a linear relationship between the intensity of the PVA-iodine color and the degree of polymerization of fractionated PVA, $D_{620} \propto \mathrm{DP}^{14}$ ). A relationship between $d_{\max }$ corrected for molecular weight by the above equation ( $d_{\max }$ was used instead of $D_{620}$ ) and the fraction number are shown in Figure 5. The data of Sample B in Figure 5 were converted to a concentration of $15 \mathrm{mmol} / 1$ of PVA in order to compare directly with data of Sample A. The linear relationship between the corrected $d_{\max }$ and the fraction number also indicates that molecular weight is not main factor of the change of $\mathrm{d}_{\max }$.

The 1,2-glycol content of the fractions was almost constant, hence the fractionation with respect to the $1,2-$ glycol content did not occur, and the 1,2-glycol content can not explain the decrease of the color. This result does not deny the possibility of foam fractionation according to the 1,2-glycol structure of 


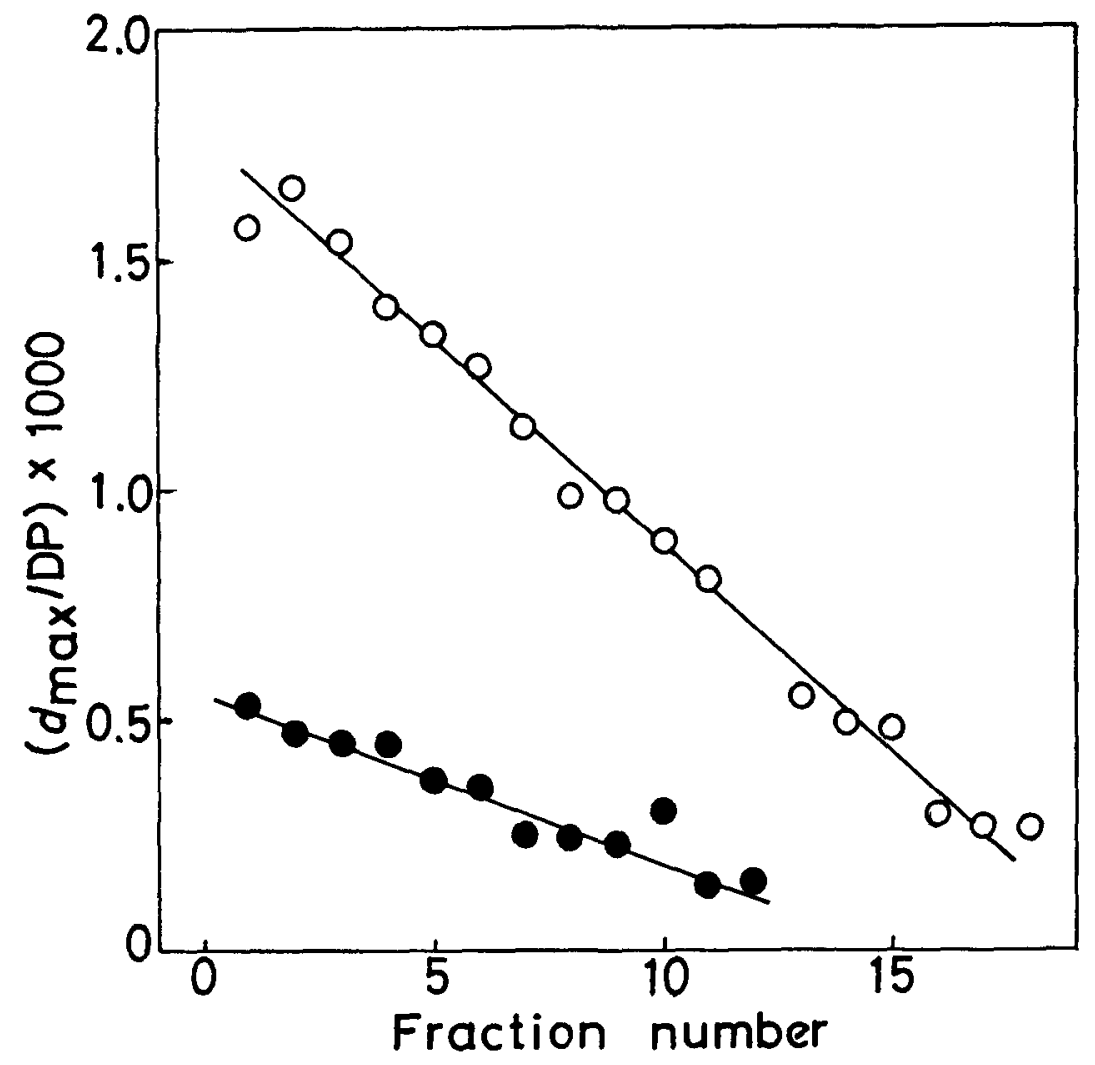

Figure 5. Corrected Absorbance for the Iodine-Color Reaction of Fractions

O; Sample A

- Sample B. The data of Sample B were converted to 15mmol/l PVA concentration 
PVA in general but represents the homogeneity of the PVA specimens. Figure 2 shows that tacticity of the fretions of Sample A was nearly equall to each other and to that of the original PVA. Since Sample A is obtained from radically polymerized PVAc, the sequence of stereoregularity probably follows randon distribution. Thus an appreciable difference should not be present concerning stereoregularity amon $n_{0}$ individual polymer molecules and hence each fractions. The constancy of absorption maximum in the $I_{2}$ color reaction also represents the homogeneity of the tacticity of Sample $A^{5)}$. Then, the decrease of $d_{\max }$ at Sample A with the increase of fraction number can not be explained by stereoregularity On the other hand, the syndiotacticity of the fractions of Sample B was higher than that of the original PVA, and the foam was unstable and the yield of foam was low compared with sample A though a difference in tacticity among the fractions was not found. This results suggest that a considerable syndiotacticity is necessary for producing a stable foam and that the foam franctionation with respect to stereoregularity has occurred for Sample B. A lerge hypsochromic shift of absorption maximum of Sample $B$ with fraction numbers(Table IV) also shows the fractionation with respect to stereoregularity because an isotactic PVA shows the hypsochromic shift at the PVA-iodine color reaction ${ }^{5)}$. Sample B is probably heterogeneous with respect to stereoregularity $^{15)}$. The high conversion and the elevation of tenperature at the beginning of the polymerization may be one of the reason for 
the roduction of the polymer molecules with different stereoregularity. In contrast, a successive change of tacticity was not found among the foam fractions as shown in figure 2 . The $d_{\max }$ of the frections, however, decreased with the increase of the fraction number, though the difference in this case was smaller than that in the case of Sample A(Figure 5). The d $d_{\max }$ of Sample $B$ of the residual solution was more intense than that of original PVA but these $d_{\max }$ might not be directly compared with because of the large difference of $\lambda_{\max }$. Figure 6 shows the plots of the corrected $d_{\max }$ against syndiotacticity; these plots also shows that the gradual decrease of $d$ max does not correlate with stereoregularity. Namely the stereoregularity is not a main factor govering the difference of the color reaction of PVA among the fractions.

Go et al. rejor ed that a mechanical stirring of an aqueous PVA solution yielded precipitates of PVA with different color intensity of the PVA-iodine reaction in spite of the same syndiotacticity as that of the original PVA $\left.{ }^{13}\right)$. They suggest that the difference of sequence length of syndiotactic part of each PVA is not the same. This suggestion, however, may not be reasonable in the present case because the FVA obtained by radical polymerization may consist of random sequence distribution of stereoregularity and the difference between polymer molecules is probably small.

The presence of carbonyl group in the main chain is revealed 


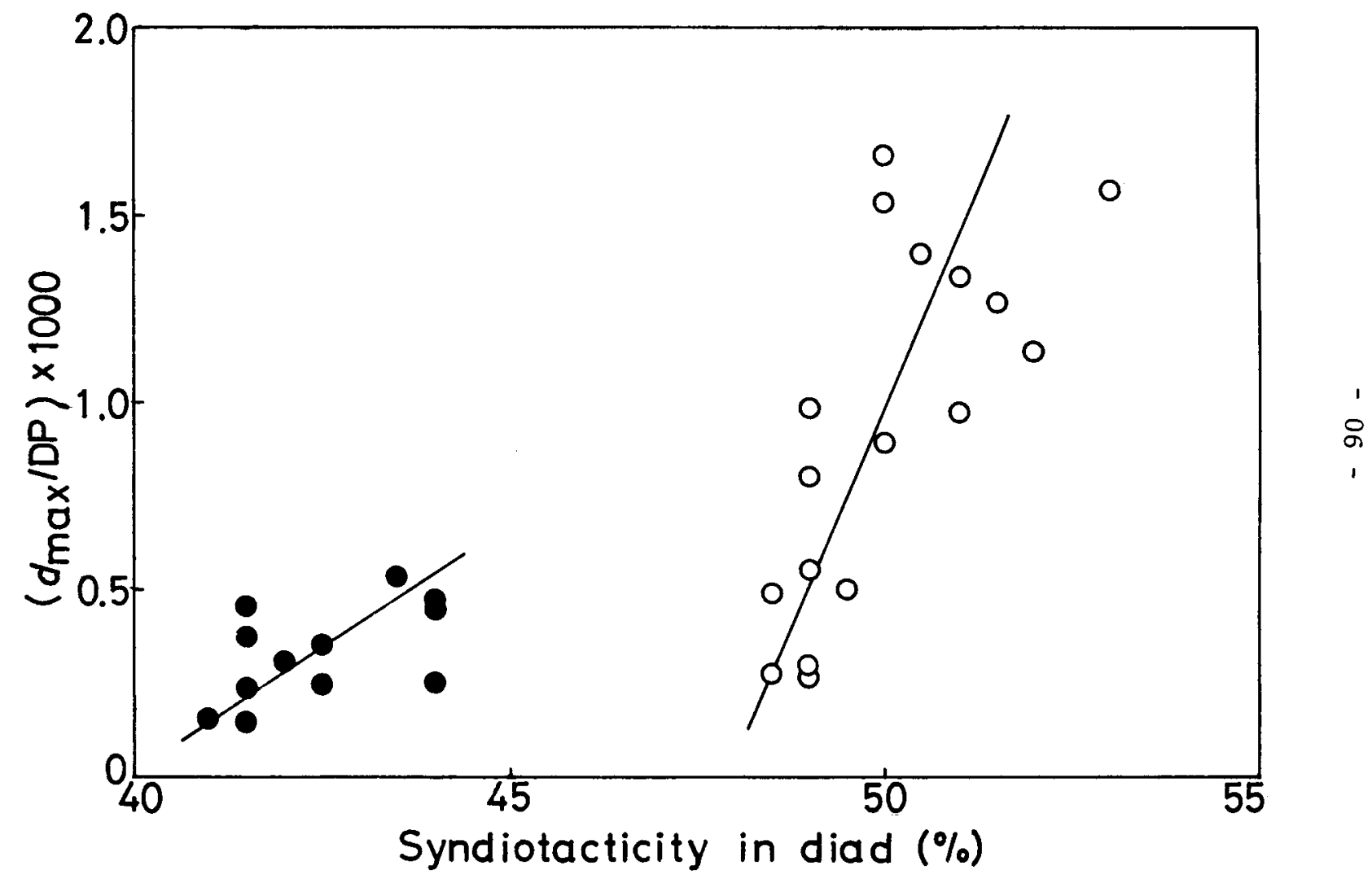

Figure 6. Relation between the Iodine-Color Reaction and Tacticity O; Sample A,

; Sample B 
by the absorption maximum at $230 \mathrm{n} \mu$ (Sample A), $240 \mathrm{~m} \mu$ (Sample B) and $280 \mathrm{~m} \mu$. Figure 3 shows the plots of the absorbance of $230 \mathrm{m \mu}$ and $240 \mathrm{~m} \mu$, which have been assigned to the $-\mathrm{C}-\mathrm{C}=\mathrm{C}$ structure, against the fraction number. Roughly speaking the early fractions tend to show stronger absorptions. These results disagree with the conventional information that the presence of abnormal structures disturbs the gelation and the PVA-1odine reaction. Thus the presence of carbonyl groups in the main chain is not a main factor on the change of PVA-iodine reaction.

Consequently none of molecular weight, stereoregularity, the 1,2-glycol structure, and carbonyl group in the main chain may be a main factor govering the decrease of the color intensity of PVA-iodine reaction with the increase of fraction number. Other factors should be considered.

One of the possible structural variations which will affect the cystallinity and PVA-iodine reaction is branching of PVA, though the presence of branching on PVA has not been investigated in detail.

Imoto et al. reported that long branching, which was prepared by the chain transfer on the backbone of PVA, was scarecely found ${ }^{16)}$. Murahashi et al. have found that long branching on PVA does not affect the PVA-iodine reaction ${ }^{17}$ ). This result is reasonable, for the presence of long branching probably show little effect with respect to the microstructure of PVA because of small number of 
branching point per a pulymer molecule.

Short branching has not been confirmed and its presence has been only speculated. The pr sence of short branching, however, seems reasonable because of a similar reactivity of the vinyl acetate radical to that of ethylene and from the consideration of the chain transfer rection of model compounds ${ }^{18}$. Short branching may be produced by the back biting mechanism. The high conversion will lead up to the low monomer concentration, and hence will produce different PVA molecules with respect to the frequency of short branching. In addition the gelation area of PVA surface film( $10 A^{2} /$ monomer unit) is equall to or less than the calculated two dimensional surface area of closed packing $\left(\sim 12 \mathrm{~A}^{2} /\right.$ monomer unit $)$, and the polyiner molecules should be brought close to each other at gelation ${ }^{19)}$. Therefore the presence of short branching probably disturbs both the PVA-iodine reaction and the formation of stable foam, the foam fractionation with respect to short branching being possible. At present, however, we must await the developement of a technique for the measurement of short branching.

In the case of Sample 3 prepared from the cationic polymerization, the color intensity of PVA-iodine reaction was weak owing to low syndiotacticity. It is noteworthy that color intensity of PVA contained in foam layers decrease with the increase of fraction number similar to the case of Sample A. 
References

1. K. Imai and M. Matsumoto, Bull. Chem. Soc. Japan, 36, 455(1963)

2. S. Murahashi, S. Nozakura, M. Sumi, H. Yuki and K. Hatada, J. Polym. Sci., B4, 65(1966), Kobunshi Kagaku, 23, 605(1966)

3. S. Murahashi, S. Nozakura, M. Sumi and K. Matsumura, J. Polym. Sci., B4, 59(1966), M. Sumi, K. Matsumura, R. Ohno, S. Nozakura and S. Murahashi, Kobunshi Kagaku, 24, 606(1967), S. Murahashi, S. Nozakura and M. Sumi, J. Polym. Sci., B3, 245(1965), S. Murahashi, S. Nozakura, M. Sumi, S. Fuji, and K. Matsumura, Kobunshi Kagaku, 23, 550(1966)

4. K. Kikukawa, S. Nozakura and S. Murahashi, Kobunshi Kagaku, 25, 19(1968), Chapter III in this paper

5. K. Kikukawa, S. Nozakura and S. Murahashi, Polymer J. in press, the preceding chapter

6. K. Shibatani, M. Nakamura and Y. Oyanagi, Kobunshi Kagaku, 26, $118(1969)$

7. A. Nakajima and K. Furudate, Kobunshi Kagaku, 6, 460 (1949)

8. H. E. Harris and J. G. Pritchard, J. Polym. Sci., A2, 3673(1961)

9. J. P. Flory and F. S. Leutner, J. Polym. Sco., 3, 880(1948)

10. D. G. Lloyd, J.Appl. Polyn. Sci., I, 70(1959)

11. H. Kishimoto, Koroido to Kaimenkasseizai, 2, 494(1961)

12. T. Sasaki, Kogyo Kagaku Zasshi, 58, 809(1955)

13. K. Nakamura, S. Matsuzawa and Y. Go, Kobunshi Kagaku, 25, $577(1968)$

14. K. Imai and M. Matsumoto, J. Polym. Sci., 52, 335(196I) 
15. M. Sumi, S. Nozakura and S. Murahashi, Kobunshi Kagaku, 24, $424(1967)$

16. S. Imoto, J. Ukida and T. Kominami, Kobunshi Kagaku, 25, 101 (1957)

17. Y. Morishim, S. Nozakura and S. Murahashi, to be published

18. J. T. Clarke, R. O. Howard and W. H. Stockmayer, Nakromol. Chem. 44-46, 427(1961) 